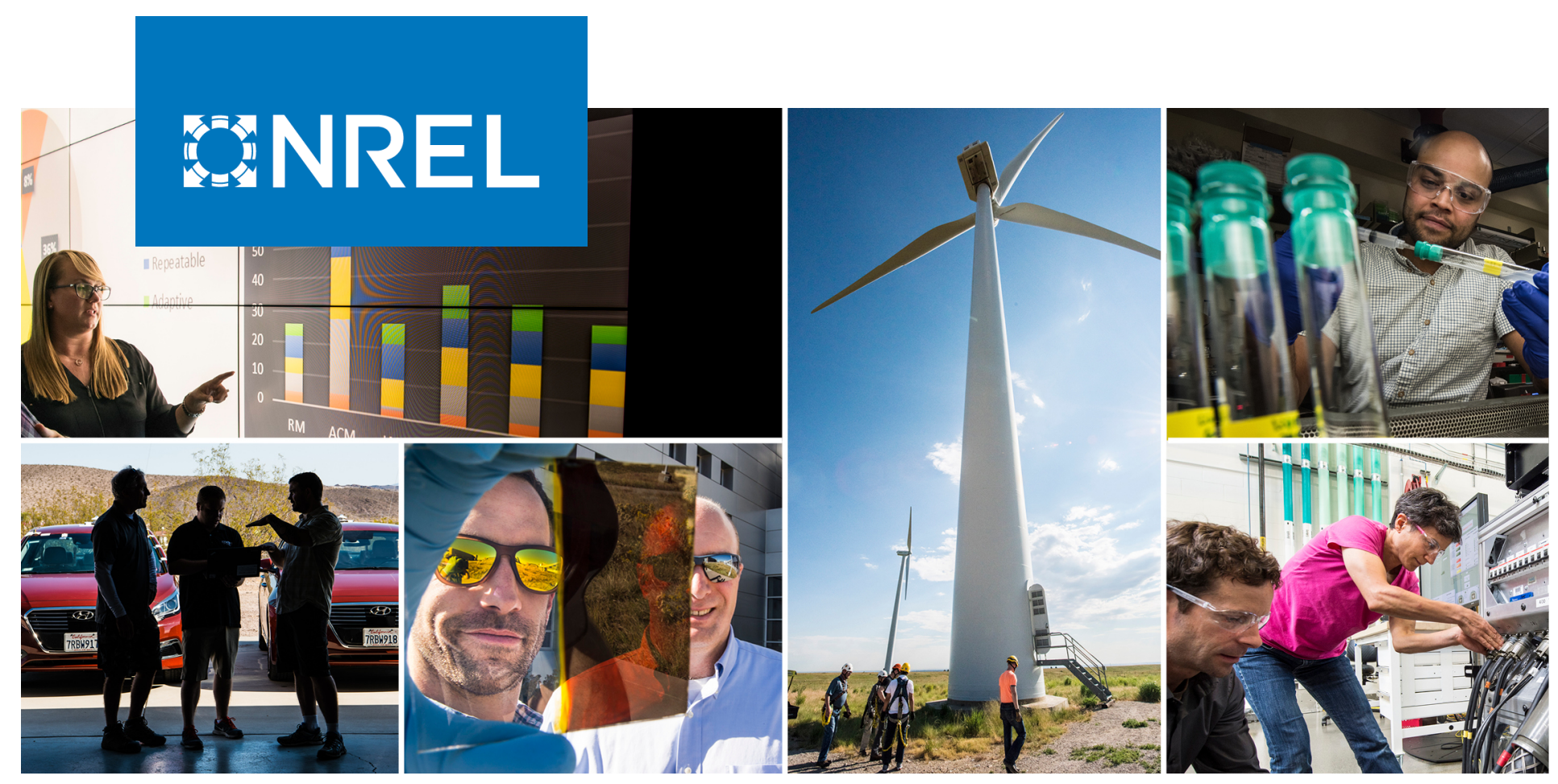

\title{
A Circular Economy for Solar Photovoltaic System Materials: Drivers, Barriers, Enablers, and U.S. Policy Considerations
}

Taylor L. Curtis, Heather Buchanan, Ligia Smith, and Garvin Heath

National Renewable Energy Laboratory

NREL is a national laboratory of the U.S. Department of Energy Office of Energy Efficiency \& Renewable Energy

Operated by the Alliance for Sustainable Energy, LLC

This report is available at no cost from the National Renewable Energy Laboratory (NREL) at www.nrel.gov/publications.
Technical Report

NREL/TP-6A20-74550

Revised April 2021 


\title{
GNREL
}

\section{A Circular Economy for Solar Photovoltaic System Materials: Drivers, Barriers, Enablers, and U.S. Policy Considerations}

\author{
Taylor L. Curtis, Heather Buchanan, Ligia Smith, \\ and Garvin Heath
}

National Renewable Energy Laboratory

\section{Suggested Citation}

Curtis, Taylor L., Heather Buchanan, Ligia Smith, and Garvin Heath. 2021. A Circular

Economy for Solar Photovoltaic System Materials: Drivers, Barriers, Enablers, and U.S. Policy Considerations. Golden, CO: National Renewable Energy Laboratory. NREL/TP-6A20-74550.

https://www.nrel.gov.docs/fy21osti/74550.

NREL is a national laboratory of the U.S. Department of Energy Office of Energy Efficiency \& Renewable Energy Operated by the Alliance for Sustainable Energy, LLC

This report is available at no cost from the National Renewable Energy Laboratory (NREL) at www.nrel.gov/publications.

Contract No. DE-AC36-08GO28308
Technical Report

NREL/TP-6A20-74550

Revised April 2021

National Renewable Energy Laboratory 15013 Denver West Parkway Golden, CO 80401

303-275-3000 • www.nrel.gov 


\section{NOTICE}

This work was authored by the National Renewable Energy Laboratory, operated by Alliance for Sustainable Energy, LLC, for the U.S. Department of Energy (DOE) under Contract No. DE-AC36-08GO28308. Funding provided by the National Renewable Energy Laboratory Planning and Assessment Circular Economy for Energy Materials Steering Committee. The views expressed herein do not necessarily represent the views of the DOE or the U.S. Government.

This report is available at no cost from the National Renewable Energy Laboratory (NREL) at www.nrel.gov/publications.

U.S. Department of Energy (DOE) reports produced after 1991 and a growing number of pre-1991 documents are available free via www.OSTI.gov.

Cover Photos by Dennis Schroeder: (clockwise, left to right) NREL 51934, NREL 45897, NREL 42160, NREL 45891, NREL 48097, NREL 46526.

NREL prints on paper that contains recycled content. 


\section{Errata}

This report, originally published in March 2021, has been revised in April 2021 to correct the spelling of a name and to update several affiliations in the acknowledgments section; correct grammatical errors; and provide clarification in certain sections of the report. 


\section{Acknowledgments}

We gratefully acknowledge the National Renewable Energy Laboratory (NREL) Planning and Assessment Circular Economy for Energy Materials Steering Committee for its funding support. We also acknowledge John "Jack" Wadleigh and Anabelle Chaffin of NREL for their research support. And we thank the following report reviewers for their time and expertise: Kristen Ardani, Doug Arent, Dan Bilello, Tina Eichner, Margaret Mann, Gian Porro, Julien Walzberg, Mary Werner, and Mike Meshek (editor) NREL, Ken Boyce, UL; Amanda Cotton and John Gilkeson, Minnesota Pollution Control Agency (MPCA); Kathy Lett, U.S. Environmental Protection Agency (EPA); Chuck Figur, EPA, Region 8; Erik Stikes and Vince Lucia, Good Sun; Jennifer Martin, Illinois Sustainable Technology Center (ISTC); Parikhit (Ricky) Sinha, First Solar; Daniel Stoehr, Daniels Training Services, Inc.; David Wagger, Institute for Scrap Recycling Industries (ISRI); Jordan Rivera and Neal Suchak, U.S. Department of Transportation; and Sam Vanderhoof and Peter Beadle, Recycle PV, LLC.

We also thank the following for their time and expertise: Evelyn Butler, Solar Energy Industries Association (SEIA); Matthew Garamone, Environmental Management Services, LLC; Nancy Holm, (formerly) ISTC; Emily Kaps, Colorado Department of Public Health and Environment; Tim Kimmel, (formerly) Cleanlites Recycling; Christine Haun and Robert Rieck, Washington State Department of Ecology; Gary Winslow, MiaSolé; Chris Newman and Lia Yohannes, U.S. EPA; Kristy Hartman, National Conference of State Legislatures; Megan Cleveland, (formerly) National Conference of State Legislatures; Madalyn Cioci, MPCA; Casey Hines and Amanda Tischer-Buros, Dynamic LifeCycle Innovations; Danielle Waterfield, ISRI; Kate Collardson, CertainTeed; Amanda Bybee, Amicus O\&M Cooperative; John Martorano, Magnum Computer Recycling; Paulina Kolic and Teresa Bui, CalRecycle; Cara Libby, Ken Ladwig, and Stephanie Shaw, Electric Power Research Institute. 


\section{List of Acronyms}

ANSI

BOS

c-Si

$\mathrm{Cd}$

C.F.R.

CPUC

DOT

DTSC

EPC

EoL

EPA

GW

IBC

ICAO

IEA

IEEE

IRENA

ISTC

$\mathrm{kg}$

$\mathrm{kW}$

LMI

Mt

MW

NEC

NFPA

NREL

O\&M

OECD

PV

R\&D

RCRA

SEIA

TCLP

$\mathrm{Te}$

TSDF

UL

WET
American National Standards Institute

balance of system

crystalline silicon

cadmium

Code of Federal Regulations

California Public Utilities Commission

U.S. Department of Transportation

Department of Toxic Substances Control (California)

engineering, procurement, and construction

end-of-life

U.S. Environmental Protection Agency

gigawatt

International Building Code

International Civil Aviation Organization

International Energy Agency

Institute of Electrical and Electronics Engineers

International Renewable Energy Agency

Illinois Sustainable Technology Center

kilogram

kilowatt

low and moderate income

metric ton

megawatt

National Electrical Code

National Fire Protection Association

National Renewable Energy Laboratory

operation and maintenance

Organization for Economic Cooperation and Development

photovoltaic

research and development

Resource Conservation and Recovery Act of 1976

Solar Energy Industries Association

Toxicity Characteristic Leaching Procedure

telluride

treatment, storage, and disposal facility

Underwriters Laboratories

Waste Extraction Test 


\section{Executive Summary}

Solar photovoltaics (PV) are an important element to a zero-carbon energy transition in the United States and around the world. National and international policy focused on reducing carbon emissions and increasing electric grid resiliency, coupled with decreasing installation costs continue to drive demand for PV (NCSL 2021; NREL 2020; IHS Markit 2020; Wesoff and Beetz 2020). In the U.S. alone, cumulative installed PV capacity exceeded 95 gigawatts $(\mathrm{GW})_{\mathrm{dc}}$ at the end of 2020 (Perea et al. 2021). If current trends persist, PV is expected grow faster than any other renewable energy sector in the United States and cumulative installed PV capacity could exceed $202 \mathrm{GW}_{\mathrm{dc}}$ by 2025 (Perea et al. 2021; IEA 2020; Shellenberger 2020; SEIA 2020).

The rapid growth and expected continual demand for PV, and the growing volume of retired PV equipment (e.g., modules) in the United States has led to supply chain and environmental concerns. In the last decade, the United States has lost $80 \%$ of its global market share for solargrade polysilicon, PV cells, and PV modules (Sun et al. 2020; Mints 2020; Smith and Margolis 2019). The United States is also dependent on imports for PV manufacturing material, PV cells, PV modules, and balance of system (BOS) equipment ${ }^{1}$ to meet domestic demand (Sun et al. 2020; Mints 2020; Smith and Margolis 2019). In 2017, the United States imported $92 \%$ of the domestic market demand for crystalline silicon (c-Si) and thin-film modules and relied entirely on imported wafers to meet domestic manufacturing needs (Smith and Margolis 2019). Similarly, in 2019, U.S. manufacturers reported they relied entirely on glass imports to meet domestic c-Si module manufacturing needs (Smith and Margolis 2019).

In addition, as the demand for PV increases, so will the need to mine virgin materials (e.g., silicon, indium, silver, tellurium, copper) and manufacture new PV products. Virgin materials are finite and are often found, refined, and used in PV product manufacturing in countries with less-stringent environmental and human health regulations. Moreover, as PV capacity increases in the United States so will the volume of decommissioned ${ }^{2}$ and end-of-life (EoL) ${ }^{3}$ PV modules and BOS equipment. At approximately 80-100 metric tons (Mt) of PV modules per megawatt (MW), modules installed in the United States today will eventually result in 7.6 million to 9.5 million metric tons of EoL modules (SEIA 2020; Weckend, Wade, and Heath 2016).

As the volume of retired PV modules and BOS equipment grows and the demand for PV system materials increases, U.S. industry stakeholders, regulators, and policymakers are starting to 1) consider solutions to drive and enable environmentally sustainable PV system equipment ${ }^{4}$ management decisions and behaviors, and 2) identify barriers to a circular economy for PV system materials. Circular economy principles attempt to transition from a "take-make-consumedispose" linear economic system to a circular model that allows for the long life, high

\footnotetext{
${ }^{1}$ This report uses "balance of system (BOS) equipment" to mean the component parts or equipment of a PV system (e.g., inverters, racking, junction box, wires, frame, mounting equipment), excluding the PV module.

2 This report uses "decommission" to mean PV modules and BOS equipment, which have been removed from firstuse system operation and may still have reuse potential.

${ }^{3}$ This report uses "end-of-life" to mean PV modules and BOS equipment that have reached the end of their expected life (i.e., a 30-year lifetime for PV modules) and do not have reuse potential.

${ }^{4}$ This report uses "PV system equipment" to mean the component parts of a PV system (e.g., inverters, racking, junction box, wires, frame, mounting equipment), including the PV module.
} 
performance, and the reuse/recovery of products and materials (Ellen MacArthur Foundation 2020).

In this report we analyze drivers, barriers, and enablers to a circular economy for PV system materials in the United States. We also analyze federal, state, and local requirements that apply to the reuse, recycling, and disposal of PV modules and BOS equipment, as well as the legal liability associated with non-compliance. We then discuss state policies and initiatives in the United States that expressly address reuse, recycling, and disposal of PV system equipment. We conclude by providing case studies of U.S. business models for the repair, reuse, recycling of PV modules and BOS equipment. Some of our findings are discussed below:

\section{$\underline{\text { Drivers of a Circular Economy for PV System Material }}$}

We found that new and expanded market opportunities, job creation, supply chain stability, and reduced negative environmental impacts are drivers for federal, state, and local government investment in the repair, reuse and recycling of PV system equipment. Early retired PV modules often maintain between $70 \%-95 \%$ of their nameplate capacity and have been reused in grid-tied and off-grid applications (NREL 2019a; SEIA 2019a; Solar ABC's 2011; CESA 2017; Sherwood 2013). ${ }^{5,6}$ Existing domestic businesses (e.g., PV manufacturers, installers, O\&M, EPC, waste management companies, reverse logistic companies, third party recyclers) could expand and new companies could emerge to provide PV system decommissioning, and PV equipment repair, reuse, and recycling products and services (Ludt 2019). ${ }^{7,8}$ In addition, recycling PV manufacturing scrap and PV equipment diverts valuable materials from landfills and could reduce U.S. dependence on foreign imports and bolster domestic manufacturing. Extending the useful life of PV equipment through repair and reuse, and recovering PV materials through recycling also lowers lifecycle environmental impacts by reducing the energy output, costs, other environment pollutants (e.g., greenhouse gas emissions) associated with mining, transporting, refining virgin materials, and manufacturing and distributing new PV equipment (Salim et al. 2019; NREL 2019a; Libby and Shaw 2018; Kalmykova et al. 2018; Xu et al. 2018; Corcelli et al. 2017; Dominguez and Geyer 2017; Weckend, Wade, and Heath 2016; Ghisellini et al. 2016; Mulvaney 2019; Heath et al. 2020).

We also found that cost savings, increased profits, and enhanced competitiveness are drivers to private investment in product and process innovation and the reuse and recovery of PV manufacturing scrap, modules, and BOS equipment. Manufacturers and system owners could sell early retired PV modules to generate revenue or donate modules for charitable use and receive a tax credit (SEIA 2019a; Libby and Shaw 2018). ${ }^{9,10}$ Manufacturers could lower costs by recycling and using recovered materials from PV manufacturing scrap, customer warranty returns, and other retired PV equipment. Manufacturers, system owners, and third-party recyclers may also generate revenue by selling recovered materials into commodity markets. Moreover, companies that engage in environmentally sustainable business practices, such as reuse and recycling, may

\footnotetext{
${ }^{5}$ Eric Stikes and Vince Lucia, Good Sun, teleconference, August 26, 2019

${ }^{6}$ Sam Vanderhoof, Recycle PV, teleconference, September 5, 2019

${ }^{7}$ Eric Stikes and Vince Lucia, Good Sun, teleconference, August 26, 2019

${ }^{8}$ Sam Vanderhoof, Recycle PV, teleconference, September 5, 2019

${ }^{9}$ Eric Stikes and Vince Lucia, Good Sun, teleconference, August 26, 2019

${ }^{10}$ Sam Vanderhoof, Recycle PV, teleconference, September 5, 2019
} 
in turn increase consumer confidence in secondary market products and their overall competitiveness in the marketplace (Salim et al. 2019; NREL 2019a; Libby and Shaw 2018; Kalmykova et al. 2018; Xu et al. 2018; Corcelli et al. 2017; Dominguez and Geyer 2017; Weckend, Wade, and Heath 2016; Ghisellini et al. 2016; Mulvaney 2019; Heath et al. 2020).

\section{Barriers to a Circular Economy for PV System Material}

We found that repair, reuse, and recycling markets for PV in the United States are nascent but there are a number of barriers that impede these options from being a viable alternative to disposal. For example, there is no standardized testing process in place to determine the safe and reliable reuse of PV modules and BOS equipment. Similarly, although there is a growing number of third-party recyclers that accept PV modules in the United States, current technologies, processes and services are not optimized for cost-effective recovery (Curtis et al. 2021b; Salim et al. 2019; Heath et al. 2020; Tura et al. 2018). Consequently, repair and reuse options are limited and there are few publicly known demonstration-projects to enable consumer confidence in reused PV modules and BOS equipment. Moreover, the cost of module recycling in the United States is often outweighed by cheaper, more accessible disposal options. Anecdotal evidence suggests that the cost of module recycling in the United States ranges from \$15-45 per module, and one study found that disposal tipping fees at a non-hazardous landfill can cost less than $\$ 1$ per module (\$26/U.S. ton) and less than $\$ 5$ per module at hazardous waste landfills (\$175/U.S. ton) (Curtis et al. 2021a; ASES 2020; CSSA 2020; Ablison Energy 2020; Evergreen Solar 2020; Intermountain Wind \& Solar 2020; CitiGreen, Inc. 2019; Green Coast 2019; Alba Energy 2018; EnergySage 2018; Libby and Shaw 2018). ${ }^{11}$ As a result, today, there is scant evidence of PV equipment reuse and less than $10 \%$ of EoL modules are recycled in the United States (ASES 2020; CSSA 2020). By comparison, in Europe, where countries have nationwide policies that mandate PV module recycling, the cost of recycling is as low as $\$ 0.70$ per module and recycling rates are as high as 95\% (CSSA 2020; ASES 2020).

We also found limited motivation or incentives for repair, direct reuse, recycling (herein repair/reuse/recycling) or for private investment in new and expanded PV circular economy market opportunities. There is limited publicly available information and data regarding the true costs of repair/reuse/recycling of PV modules, which take into account the disassembly, infrastructure needs (e.g., collection centers or equipment), regulatory compliance, and reverse logistics (e.g., sorting, handling, or transport) (Curtis et al. 2021b). Moreover, there is little data available regarding the value of and markets for reused PV modules and recovered PV materials to inform investment decisions. In addition, state and local interconnection, fire, building, and electric regulations in the United States may directly prohibit the reuse of PV modules or BOS equipment for certain grid-tied and off-grid applications. There is also limited publicly available information on projects that demonstrate the quality, performance, safety and technical viability of repaired and reused PV equipment which may impact consumer trust and confidence in secondary market products (Curtis et al 2021b). Moreover, federal and state solid waste and transportation laws often regulate PV modules destined for resource recovery in the same

\footnotetext{
${ }^{11}$ We calculated the per module disposal cost by estimating a typical module weight of 33-50 pounds (Ablison Energy 2020; Evergreen Solar 2020; Intermountain Wind \& Solar 2020; CitiGreen, Inc. 2019; Green Coast 2019; Alba Energy 2018; EnergySage 2018; Wholesale Solar 2011) and using the per ton landfill tipping costs of \$26/ U.S. ton to $\$ 89 /$ U.S. ton for nonhazardous Subtitle D landfills and \$175/U.S. ton for hazardous Subtitle C landfills provided by (Libby and Shaw 2018).
} 
manner as PV modules destined for disposal, which does not provide an incentive for recycling, especially when the economics and accessibility of disposal are more favorable (Curtis et al. 2021b).

\section{Enablers to a Circular Economy for PV System Material}

Policy ${ }^{12}$ can help enable a circular economy for PV material in the United States. Governmentfunded research and development (R\&D) and analysis could enable private investment in new and expanded PV market opportunities by providing answers to questions that could help alleviate market uncertainty and lead to more efficient cost-effective technologies, processes, and services for the reuse and recycling of PV system equipment (Curtis et al. 2021b). For example, repowering data could aid decommissioning projections and accurate data regarding the average condition of retired PV modules (e.g., remaining capacity) could inform supply projections and help identify viable secondary applications. For recycling, R\&D and analysis focused on optimizing cost-effective recovery of high-purity materials at high recovery rates could aid private investment by making the economics of recycling more desirable (Heath et al. 2020). Policy can also mandate or incentivize the reuse and recycling of PV system equipment, which is needed to enable sustainable material management practices until there are more accessible repair and reuse options, and the economics of recycling are competitive with disposal (Curtis et al. 2021b). For instance, government subsidies, grants and awards could be used to reduce financial risk and make early investment for private industry more desirable. Policies could also mandate reuse or recycling or prohibit disposal and they could also incentivize reuse and recycling by reducing the regulatory burden and legal liability associated compared to disposal (Curtis et al. 2021b).

\section{Federal, State, and Local Legal Requirements}

In this report, we also analyze federal, state, and local legal requirements that apply to the reuse, recycling, and disposal of PV system equipment, as well as the legal liabilities associated with non-compliance. Our analysis of state and local interconnection, fire, building, and electrical regulations in the United States revealed that these regulations are often complex and vary by jurisdiction. In addition, these regulations may directly prohibit the reuse of PV modules and BOS equipment for certain grid-tied and off-grid applications. We also analyze federal solid waste requirements pursuant to the Resource Conservation and Recovery Act of 1976 (RCRA). We found that PV equipment, such as modules may be regulated as RCRA hazardous solid waste or universal waste necessitating compliance with stringent generation, handling, storage, treatment, recycling, and disposal requirements which carry civil and criminal penalties for noncompliance. Moreover, PV equipment destined for resource recovery is often regulated pursuant to RCRA in the same manner as equipment being disposed of, which does not provide a regulatory incentive to recycle. In addition, we analyze domestic transport and international transboundary export requirements which may apply to used PV equipment. We found that RCRA and U.S. Department of Transportation regulations prescribe stringent handling, storage, packaging, labeling and other transit-related requirements for road and rail transport, and sea

\footnotetext{
${ }^{12}$ We use "policy" in this report broadly to include not only federal, state, and local statutory and regulatory requirements but also government initiatives and goals.
} 
transport of used PV equipment. Further, we found that used PV equipment that is shipped abroad may be subject to international treaty requirements and export regulations.

\section{$\underline{\text { PV System Equipment Management Policies }}$}

In this report, we provide an overview of policies and initiatives in the United States that expressly address reuse/recovery and disposal of PV system equipment. We found no U.S. federal policies that address the reuse of or EoL management options for PV system equipment. Washington, New Jersey, North Carolina, and California are the only U.S. states with laws or regulations that directly address the reuse of and/or EoL management options for PV system equipment. Washington has enacted a law, which requires that PV module manufacturers finance and implement the takeback and reuse or recycling of PV modules at no cost to owners. New Jersey has enacted a law, which created a commission tasked with investigating and developing recommendations for PV module recycling. Similarly, North Carolina enacted a law, which tasks the Department of Environmental Quality with studying and adopting rules to govern PV system decommissioning, reuse, and EoL management of PV modules and BOS equipment used in utility scale projects. California also passed a law, which allows discarded hazardous PV modules to be regulated as universal waste which has less stringent handling, storing, and transport requirements than fully regulated hazardous waste. In addition, California, Hawaii, and Rhode Island have proposed bills that, if enacted, would directly address reuse, recycling, and/or disposal of PV system equipment. There are also state-led working groups in California, Illinois, and Minnesota to study reuse and EoL options for PV equipment.

\section{Case Studies: Business Models to Support a Circular Economy for PV System Equipment}

Finally, we present case studies of three U.S. solar industry business models for the repair/reuse/recycling of PV system equipment: First Solar, Inc., Good Sun, and Recycle PV Solar, LLC.

First Solar, Inc. is an American solar PV module manufacturer headquartered in Arizona that offers PV module collection and recycling. First Solar developed the first global module collection and recycling program. First Solar's collection and recycling program uses a flexible pay-as-you-go model that allows customers to decide whether and when they want to use First Solar's recycling service. The pay-as-you-go model does not impact the upfront costs of the modules' purchase price, and it allows customers to request recycling services on a per-unit basis.

Good Sun is a 501(c)(3) nonprofit headquartered in California that sells used c-Si PV modules and BOS equipment at discounted rates for secondary use and installs PV systems for charitable projects in low- and moderate-income (LMI) communities. Good Sun uses the profits from the sale of the used PV modules and BOS equipment to install PV systems and provide vocational training for LMI communities in California and Africa.

Recycle PV Solar, LLC is a solar consulting company headquartered in California that sells used and repaired c-Si PV modules at discounted rates for secondary use and coordinates the recycling of decommissioned modules to recover valuable materials. Customers may ship used PV modules to Recycle PV's partner recycling facility in Arizona or Recycle PV can arrange for 
pick up and transport the modules for an additional fee. Once a module is received, Recycle PV performs a spot-check to evaluate the module's condition to determine whether it may be directly reused, requires light repair prior to reuse (e.g., repair or replacement of BOS equipment such as wires or frame), or should be recycled. Recycle PV sells or donates PV modules that are suitable for direct reuse or which require light repair prior to reuse. ${ }^{13}$

\section{Methodology}

Our results are based on legal and literature-based research. In addition, our results incorporate feedback and information we received from a series of interviews conducted through teleconference and email exchange with a diverse group of PV experts, including academic and research organizations, industry associations, $\mathrm{PV}$ manufacturers, $\mathrm{PV}$ reuse/repair/recycling companies, and consultants, as well as U.S. federal and state regulators, and policymakers. The questions used in each interview were tailored specifically to the industry stakeholders' areas of expertise. Moreover, this report is limited to U.S. PV regulatory, policy, and market analysis.

This report is intended to inform decisionmakers, including those involved with policy design; it does not endorse any particular policy mechanism over another, nor does it assess all regulatory requirements or the impacts that those requirements and policies may have on U.S. PV markets or related commodity markets.

${ }^{13}$ Sam Vanderhoof, CEO, Recycle PV Solar, LLC, teleconference, September 5, 2019 


\section{Table of Contents}

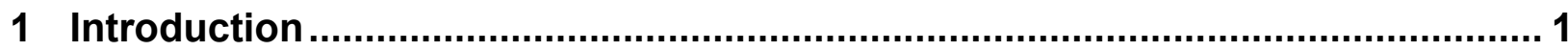

2 Drivers, Barriers, and Enablers to a Circular Economy for PV System Materials

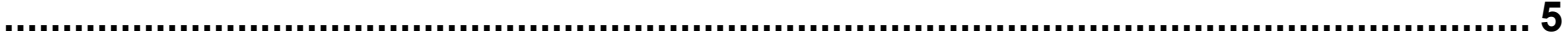

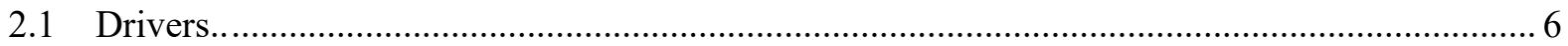

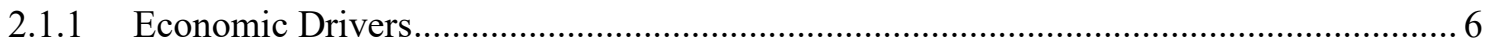

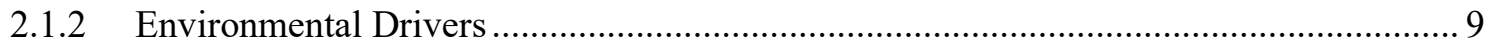

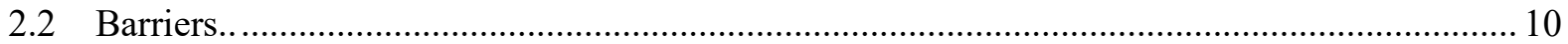

2.2.1 Technology, Infrastructure, and Process Barriers ...................................................... 10

2.2.2 Information and Data Barriers........................................................................... 12

2.2.3 Regulatory Barriers ......................................................................................... 13

2.2.4 Economic and Market Barriers............................................................................. 15

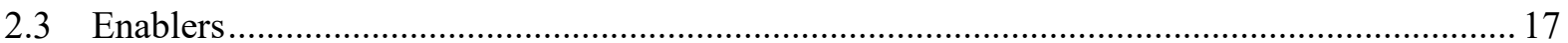

2.3.1 Research, Development, and Analysis Enablers ......................................................... 18

2.3.2 Information Availability and Exchange Enablers ...................................................... 20

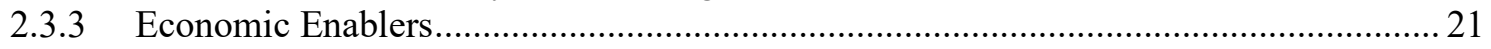

2.3.4 Regulatory and Policy Enablers ............................................................................. 22

3 Regulatory Considerations for Reuse of PV System Equipment .....................23

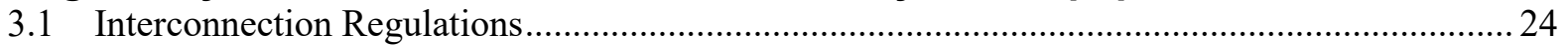

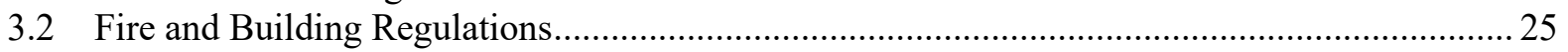

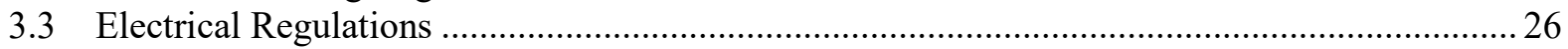

4 Statutory and Regulatory Considerations for Reuse, Recycling, and Disposal of PV System Equipment ........................................................................... 27

4.1 Regulation of PV System Equipment as Solid Waste ............................................................2 28

4.1.1 Materials Excluded from the Definition of Solid Waste …………………………….....2. 29

4.1.2 Materials Excluded from the Definition of Hazardous Solid Waste................................ 30

4.1.3 RCRA Hazardous Waste Determination....................................................................... 31

4.2 Regulation of PV System Equipment as Hazardous Waste ...................................................... 32

4.3 Regulation of PV System Equipment as Universal Waste _........................................................... 33

4.4 Comparison of Hazardous Waste and Universal Waste Handling, Storage, and Transport

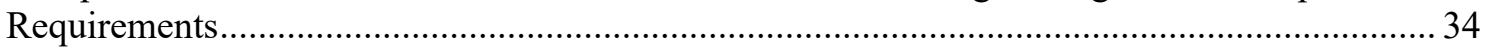

4.4.1 Generator and Handler Requirements ........................................................................... 35

4.4.2 Treatment, Storage, and Disposal Facility and Destination Facility Requirements ....... 36

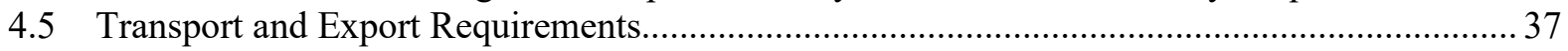

4.5.1 Transportation by Highway, Rail, Air, or Sea........................................................... 38

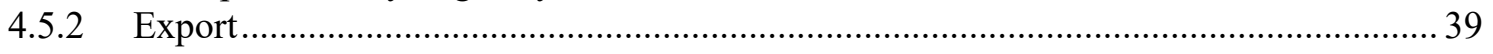

4.6 Penalties for Non-Compliance …………………………………………………………. 40

4.6.1 RCRA Hazardous and Universal Waste Regulations.................................................... 40

4.6.2 DOT Hazardous Materials Regulations ................................................................... 41

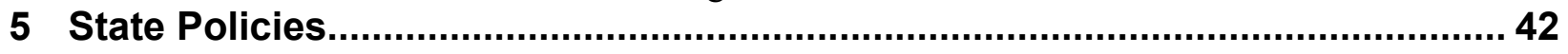

$5.1 \quad$ Enacted Legislation and Regulation..................................................................................... 43

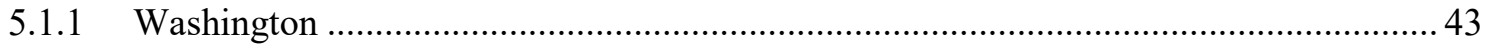

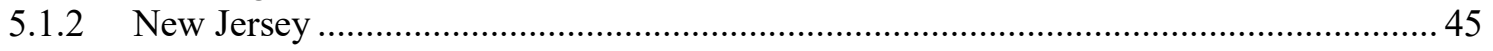

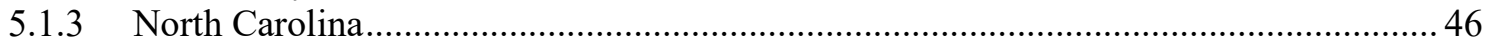

5.1.4 California............................................................................................... 47

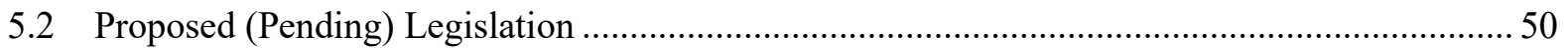

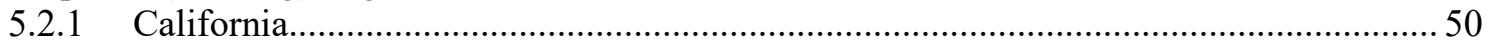

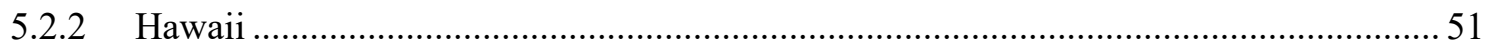

5.2.3 Rhode Island ...................................................................................................... 51 


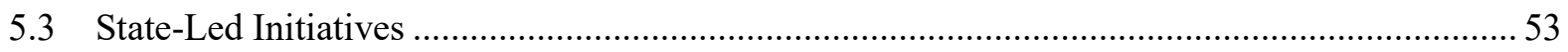

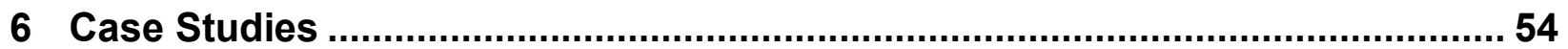

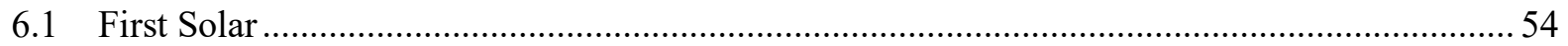

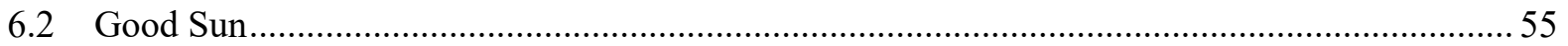

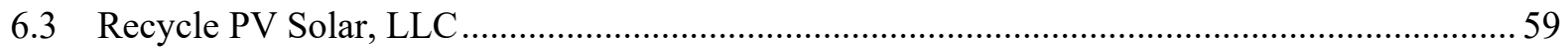

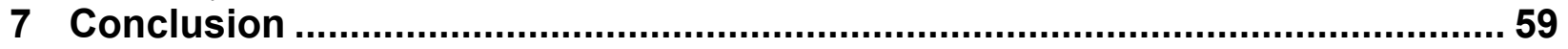

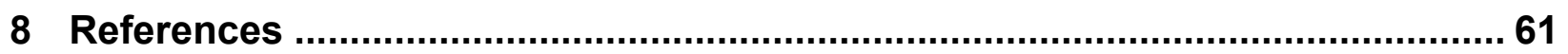

9 Legislative and Executive Documents ....................................................... 72

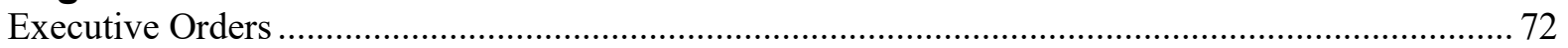

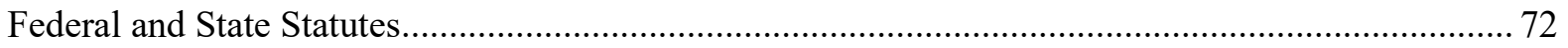

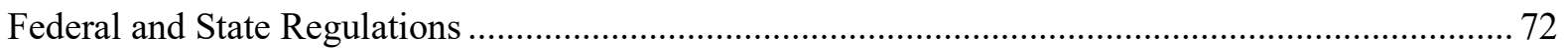

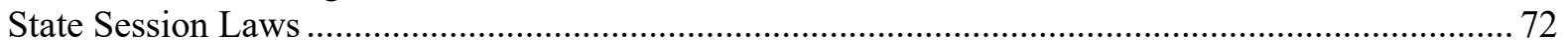

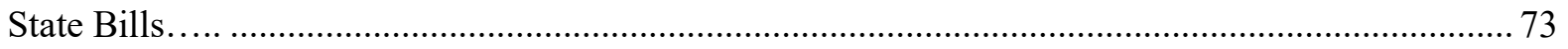

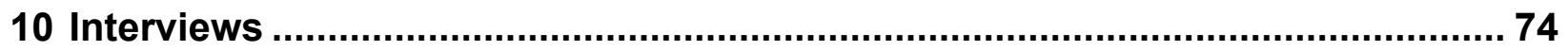




\section{List of Figures}

Figure 1. A circular economy for PV system materials ...................................................................... 3

Figure 2. State PV system decommissioning, and PV equipment reuse and EoL management policies

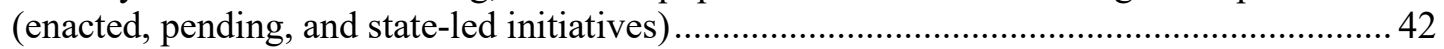

\section{List of Tables}

Table 1. Drivers of a Circular Economy for PV System Materials......................................................... 6

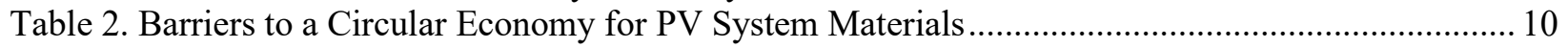

Table 3. Enablers to a Circular Economy for PV System Materials.......................................................... 17

Table 4. Regulatory Considerations for Reuse of PV System Equipment............................................. 24

Table 5. Regulatory Considerations for the Reuse, Recycling, and Disposal of PV System Equipment ... 27

Table 6. Federal Hazardous Waste Generator and Universal Waste Handler Requirements ${ }^{\mathrm{a}}$.................... 35

Table 7. Federal Hazardous Waste Transporter and Universal Waste Transporter Requirements ${ }^{\mathrm{a}}$............. 37

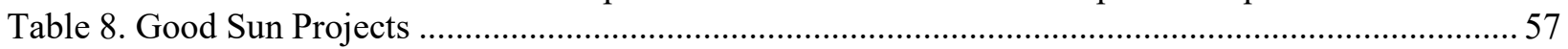




\section{Introduction}

Solar photovoltaics (PV) are an important element to a zero-carbon energy transition in the United States and around the world. National and international policy focused on reducing carbon emissions and increasing electric grid resiliency, coupled with decreasing installation costs continue to drive demand for PV (NCSL 2021; NREL 2020; IHS Markit 2020; Wesoff and Beetz 2020). In the United States alone, cumulative installed PV capacity exceeded 95 gigawatts $(\mathrm{GW})_{\mathrm{dc}}$ at the end of 2020 (Perea et al. 2021). If current trends persist PV is expected grow faster than any other renewable energy sector in the United States and cumulative installed PV capacity could exceed 202 GW $_{\text {dc }}$ by 2025 (IEA 2020; Shellenberger 2020; Perea et al. 2021; SEIA 2020).

The rapid growth and expected continual demand for PV, and the growing volume of retired PV equipment (e.g., modules) in the United States has led to supply chain and environmental concerns. In the last decade, the United States has lost $80 \%$ of its global market share for solargrade polysilicon, PV cells, and PV modules (Sun et al. 2020a; Mints 2020; Smith and Margolis 2019). The United States is also dependent on imports for PV manufacturing material, PV cells, PV modules and balance of system (BOS) equipment ${ }^{14}$ to meet domestic demand (Sun et al. 2020a; Mints 2020; Smith and Margolis 2019). In 2017, the United States imported 92\% of the domestic market demand for crystalline silicon (c-Si) and thin-film modules and relied entirely on imported wafers to meet domestic manufacturing needs (Smith and Margolis 2019). Similarly, in 2019, U.S. manufacturers reported they relied entirely on glass imports to meet domestic c-Si module manufacturing needs (Smith and Margolis 2019).

In addition, as the demand for PV increases, so will the need to mine virgin materials (e.g., silicon, indium, silver, tellurium, copper) and manufacture new PV products. Virgin materials are finite and are often found, refined, and used in PV product manufacturing in countries with less-stringent environmental and human health regulations. Moreover, as PV capacity increases in the United States so will the volume of decommissioned ${ }^{15}$ and end-of-life (EoL) ${ }^{16} \mathrm{PV}$ modules and BOS equipment. At approximately 80-100 metric tons (Mt) of PV modules per megawatt (MW), modules installed in the United States today will eventually result in 7.6 million to 9.5 million metric tons of EoL modules (SEIA 2020; Weckend, Wade, and Heath 2016).

Domestic reuse and recycling-based resource recovery of PV equipment could reduce environmental and supply chain concerns and lead to new and expanded market opportunities in the United States. However, as PV capacity increases and the future of the PV equipment waste stream becomes more certain, U.S. industry stakeholders are left facing limited material management options. In theory, management options for early retired and EoL PV equipment include repair for reuse, direct reuse, recycling-based resource recovery, storage, and disposal. Yet, in the United States repair for reuse and direct reuse (herein repair/reuse) options are limited

\footnotetext{
${ }^{14}$ This report uses "balance of system (BOS) equipment" to mean the component parts or equipment of a PV system (e.g., inverters, racking, junction box, wires, frame, mounting equipment), excluding the PV module.

15 This report uses “decommission" to mean PV modules and BOS equipment, which have been removed from firstuse system operation and may still have reuse potential.

16 This report uses "end-of-life" to mean PV modules and BOS equipment that have reached the end of their expected life (i.e., a 30-year lifetime for PV modules) and do not have reuse potential.
} 
and there are few known projects that demonstrate the viability, safety, and reliability of reused PV modules and BOS equipment. Moreover, the cost of PV module recycling in the United States is often overshadowed by cheaper and more accessible disposal options (CSSA 2020; ASES 2020). Anecdotal evidence suggests that the cost of module recycling in the United States ranges from \$15-45 per module, while one study found that disposal tipping fees at a nonhazardous landfill ( $\$ 26 /$ U.S. ton) can cost less than $\$ 1$ per module and less than $\$ 5$ per module at hazardous waste landfills (\$175/U.S. ton) (ASES 2020; CSSA 2020; Ablison Energy 2020; Evergreen Solar 2020; Intermountain Wind \& Solar 2020; CitiGreen, Inc. 2019; Green Coast 2019; Alba Energy 2018; EnergySage 2018; Libby and Shaw 2018). ${ }^{17}$ As a result, today there is scant evidence of PV equipment repair/reuse and anecdotal evidence suggest that most early retired and EoL PV modules are landfilled or otherwise disposed of resulting in less than 10\% of modules being recycled in the United States (ASES 2020; CSSA 2020; Salim et al. 2019; CPUC 2019b; DTSC 2019b; NREL 2019a). By comparison, in Europe, where countries have nationwide policies that mandate PV module recycling, the cost of recycling is as low as $\$ 0.70$ per module and recycling rates are as high as 95\% (CSSA 2020; ASES 2020).

As awareness of current practices grows, and the demand for critical PV module material increases, U.S. industry stakeholders, regulators, and policymakers are starting to (1) consider solutions to drive and enable environmentally sustainable PV system equipment ${ }^{18}$ management decisions and behaviors and (2) identify barriers to a circular economy for PV system materials. Circular economy principles (Figure 1) attempt to transition from a "take-make-consumedispose" linear economic system to a circular system that allows for the long life, and the reuse/repair/recovery of products and materials (Ellen MacArthur Foundation 2020).

\footnotetext{
${ }^{17}$ We calculated the per module disposal cost by estimating a typical module weight of 33-50 pounds (Ablison Energy 2020; Evergreen Solar 2020; Intermountain Wind \& Solar 2020; CitiGreen, Inc. 2019; Green Coast 2019; Alba Energy 2018; EnergySage 2018; Wholesale Solar 2011) and using the per ton landfill tipping costs of \$26/ U.S. ton to \$89/U.S. ton for nonhazardous Subtitle D landfills and \$175/U.S. ton for hazardous Subtitle C landfills provided by (Libby and Shaw 2018).

18 This report uses "PV system equipment" to mean the component parts of a PV system (e.g., inverters, racking, junction box, wires, frame, mounting equipment), including the PV module.
} 


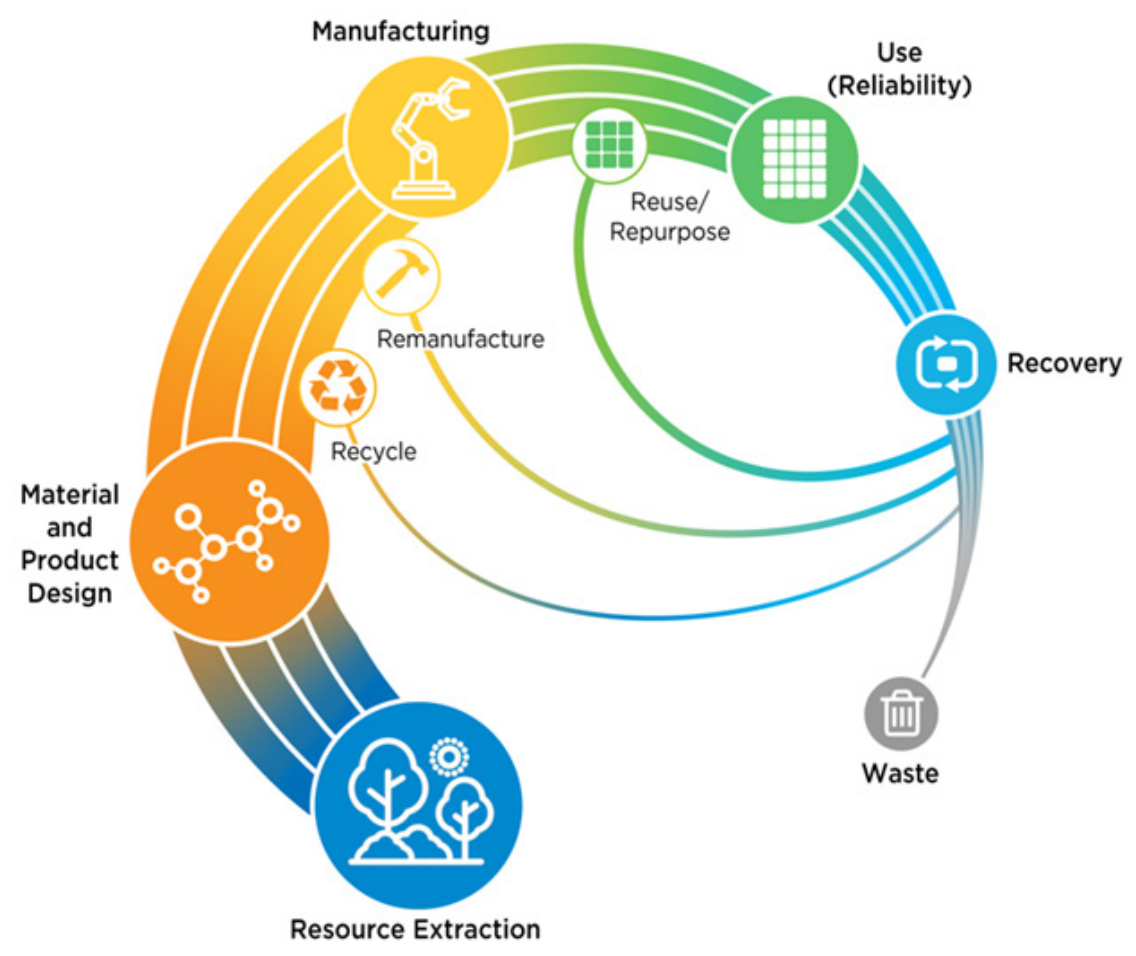

Figure 1. A circular economy for PV system materials

The repair for reuse, direct reuse, and recycling-based recovery (herein repair/reuse/recycling) of PV system equipment can increase economic benefits for solar industry stakeholders, create new and expanded U.S. market and job opportunities, increase supply chain stability, and reduce environmental impacts. Manufacturers and system owners may obtain economic benefit from selling or donating PV system equipment for secondary use, or recycling PV equipment (and manufacturing scrap) for sale into commodity markets, or for reuse in manufacturing (Salim et al. 2019; SEIA 2019a; Libby and Shaw 2018). ${ }^{19,20}$ Companies that engage in environmentally sustainable business practices such as reuse/repair/recycling may in turn increase consumer trust and overall competitiveness in the marketplace (Salim et al. 2019). Extracting additional services and revenue from PV modules and BOS equipment also increases the total lifetime value of the PV system, and the costs can be shared by primary and secondary users. Incumbent stakeholders and new market entrants alike may expand or provide new services (e.g., reverse logistics, disassembly, and recycling) to meet reuse/repair/recycling needs for PV equipment. Further, the recovery of PV materials could aid in domestic manufacturing opportunities. One estimate found that the value of recovered materials from PV modules, alone, represents a potential $\$ 60$ million U.S. industry by 2030 and a $\$ 2$ billion industry by 2050 (Weckend, Wade, and Heath 2016). In addition, recycling PV modules and manufacturing scrap can divert valuable resources from landfills, and reduce the need to mine for virgin materials, such as silicon, indium, silver, copper, and tellurium. Recovery of these materials can also reduce waste, alleviate critical resource constraints, and lower dependence on foreign markets and imports.

\footnotetext{
${ }^{19}$ Eric Stikes and Vince Lucia, Good Sun, teleconference, August 26, 2019

${ }^{20}$ Sam Vanderhoof, Recycle PV, teleconference, September 5, 2019
} 
Today there are technical, economic, and regulatory factors that inhibit a circular economy for PV system materials in the United States. As a result, few manufacturers take into account design for extended product durability or design for repair/reuse/recycling, and there are a limited number of U.S.-based companies that work to repair/reuse/recycle PV system equipment. Current technology, infrastructure, and processes associated with the reuse/recycling of PV system equipment are not optimized for efficient cost-effective repair for reuse or recovery of high-value materials. There is also limited publicly available research and market information available that could help inform investment decisions in the early stages of new and expanded PV market opportunities. In addition, the management of used PV system equipment requires compliance with complex, variable, and at times, unclear federal, state, and local U.S. laws and regulations. Moreover, there is a lack of U.S. policies that incentivize or mandate repair/reuse/recycling of PV system equipment over disposal.

PV system owners, and others involved in the management of early retired and EoL PV equipment have to consider the financial and legal liability associated with each management option. Today U.S. policy ${ }^{21}$ does not incentivize or mandate repair/reuse/recycling of PV equipment and materials over disposal. Regulation in the United States may prohibit certain secondary use applications, and mandate specific requirements that carry civil and criminal penalties for non-compliance. For example, interconnection, fire, building, and electric regulations in the United States vary by jurisdiction and may directly prohibit the reuse of PV modules and BOS equipment for certain grid-tied and off-grid applications. Moreover, PV equipment destined for resource recovery are often regulated in the same manner as those destined for disposal, which does not provide an incentive for recycling, especially when the cost of disposal is more favorable. Used PV equipment accumulated or stored before recycling or disposal, and those being recycled or disposed of may be regulated as solid waste or hazardous solid waste in the United States. Solid waste and hazardous waste laws in the United States vary by jurisdiction, and mandate specific handling, storage, and transport requirements. In addition, transporters of PV equipment regulated as hazardous or universal waste may be subject to U.S. Department of Transportation hazardous material regulations with specific packaging, documentation, and other transit-related related requirements. Further, PV equipment regulated as hazardous or universal waste, which is shipped abroad may be subject to international treaty requirements and export regulations.

U.S. policymakers, regulators, and industry stakeholders are starting to consider and evaluate how policy may drive and enable a circular economy for PV system materials. Policies could incentivize innovation in PV module design, as well as the development of PV repair/reuse/recycling services, business models and processes. Government-funded R\&D and analysis, could enable private investment in the early stages of new and expanded PV market opportunities by providing answers to questions that could help alleviate market uncertainty. Clear and consistent federal, state, and local U.S. regulation related to repair/reuse/recycling of PV system equipment could also reduce regulatory uncertainty, liability concerns, and overall investor risk. Moreover, policies designed to encourage repair/reuse/recycling over disposal may make the economics of circular options and early market investment more desirable.

\footnotetext{
${ }^{21}$ We use "policy" in this report broadly to include not only federal, state, and local statutory and regulatory requirements but also government initiatives and goals.
} 
We begin this report by summarizing the drivers, barriers, and enablers to a circular economy for PV system materials in the United States. We then report on our analysis of federal and state regulatory considerations that may impact the repair/reuse/recycling of PV equipment, and potential civil and criminal liabilities associated with non-compliance. We then discuss state policies and initiatives in the United States that expressly address PV system decommissioning and repair/reuse/recycling of PV equipment. We conclude by providing case studies of U.S. business models for the repair/reuse/recycling of PV system equipment.

Our results are based on legal and literature-based research. In addition, our results incorporate feedback and information we received from a series of interviews conducted through teleconference and email exchange with a diverse group of PV experts, including academic and research organizations, industry associations, PV manufacturers, PV reuse/repair/recycling companies, and consultants, as well as U.S. federal and state regulators, and policymakers. The questions used in each interview were tailored specifically to the stakeholders' areas of expertise. Moreover, this report is limited to U.S. PV regulatory, policy, and market analysis.

This report is intended to inform decisionmakers, including those involved with policy design; it does not endorse any particular policy mechanism over another, nor does it assess all regulatory requirements or the impacts that those requirements and policies may have on U.S. PV markets or related commodity markets.

\section{Drivers, Barriers, and Enablers to a Circular Economy for PV System Materials}

Today, PV supply chains in the United States are characterized as linear economic models. Few PV manufacturers take into account design for extended product durability, reuse or recycling, and only a few U.S.-based manufacturers have implemented a "takeback" program to reuse or recycle retired PV modules (NREL 2019a; Salim et al. 2019; First Solar 2019). ${ }^{22,23,24}$ Only a handful of third-party companies in the United States repair or resell used PV modules and BOS equipment for secondary market use. Moreover, although there are a growing number of third-party recyclers in the U.S. that accept PV modules, most companies only recover bulk material and leave behind high-value material such as silver, copper, and silicon (CPUC 2019b; Salim et al. 2019; Libby and Shaw 2018; Heath et al. 2020; First Solar 2019; Good Sun 2019; SEIA 2019b). ${ }^{25,26,27,28,29}$

\footnotetext{
${ }^{22}$ Matthew Garamone, Environmental Management Services, LLC., and Parikhit Sinha, First Solar, teleconference, March 4, 2019

${ }^{23}$ Matthew Garamone, Environmental Management Services, LLC., and Parikhit Sinha, First Solar, teleconference, August 26, 2019

${ }^{24}$ Cara Libby, Electrical Power Research Institute, email, January 14, 2021

${ }^{25}$ Evelyn Butler, Solar Energy Industries Association, teleconference, February 8, 2019

${ }^{26}$ Matthew Garamone, Environmental Management Services, LLC., and Parikhit Sinha, First Solar, teleconference, March 4, 2019

${ }^{27}$ Matthew Garamone, Environmental Management Services, LLC., and Parikhit Sinha, First Solar, teleconference, August 26, 2019

${ }^{28}$ Eric Stikes and Vince Lucia, Good Sun, teleconference, August 26, 2019

${ }^{29}$ Sam Vanderhoof, Recycle PV Solar LLC, teleconference, September 5, 2019
} 
In this section, we discuss drivers, barriers, and potential enablers of a circular economy for PV system materials in the United States. In addition to doing literature-based research, we conducted interviews and interacted with solar PV experts to identify factors that may drive, or act as a barrier, to repair/reuse/recycling of PV system equipment in the United States. These stakeholder interactions also informed potential solutions that may enable repair/reuse/recycling of PV system equipment and materials in the United States.

\subsection{Drivers}

Certain opportunities and benefits may drive a circular economy for PV system materials in the United States. In this section, we discuss economic, environmental, and security opportunities and benefits that may drive decisions and behaviors that facilitate the integration of circularity principles into PV value and supply chains. Table 1 summarizes those drivers.

Table 1. Drivers of a Circular Economy for PV System Materials

\begin{tabular}{ll}
\hline $\begin{array}{l}\text { Economic Drivers } \\
\text { (Section 2.1.1) }\end{array}$ & Potential Benefits \\
\hline $\begin{array}{l}\text { Cost savings and } \\
\text { increased profits }\end{array}$ & $\begin{array}{l}\text { Decrease manufacturing costs and achieve additional revenue } \\
\text { streams and tax benefits }\end{array}$ \\
\hline Enhanced competitiveness & $\begin{array}{l}\text { Increase a business's green or environmentally responsible image } \\
\text { and increase consumer trust }\end{array}$ \\
\hline $\begin{array}{l}\text { New and expanded market and } \\
\text { employment opportunities }\end{array}$ & $\begin{array}{l}\text { Provide opportunities for new and expanded markets, and } \\
\text { job creation }\end{array}$ \\
\hline $\begin{array}{l}\text { Environmental Drivers } \\
\text { (Section 2.1.2) }\end{array}$ & Potential Benefits \\
\hline $\begin{array}{l}\text { Reduced negative } \\
\text { environmental impacts }\end{array}$ & $\begin{array}{l}\text { Reduce waste, the generation of greenhouse gases and other } \\
\text { environmental pollutants, and the total energy required to mine, } \\
\text { transport, refine and manufacture products }\end{array}$ \\
\hline Reduced resource constraints & $\begin{array}{l}\text { Conserve high-value materials, prevent resource constraints, and } \\
\text { reduce import demand for raw materials }\end{array}$ \\
\hline
\end{tabular}

\subsubsection{Economic Drivers}

New and expanded market opportunities, job creation as well as supply chain stability and resource security may drive federal, state, and local government investment in a circular economy for PV system materials in the United States. Cost savings, increased profits, and enhanced competitiveness may drive private investment in product, service, and process innovation, and the repair/reuse/recycling of PV system equipment. This section discusses some of those economic drivers.

\subsubsection{Repair/Reuse}

Reuse of PV system equipment creates an opportunity for new and expanded market opportunities and new jobs in the United States. Industry experts have observed that decommissioned PV modules often maintain $70 \%-95 \%$ of their nameplate capacity and can be 
used in secondary applications. ${ }^{30,31}$ Early retired PV modules and BOS equipment may be suited for direct reuse, while others may require repair before reuse (NREL 2019a; SEIA 2019a). ${ }^{32,33}$ Used modules and BOS equipment are sold by PV system owners and equipment brokers on platforms such as EnergyBin for secondary use in off-grid applications as well as grid-tied applications in some U.S. jurisdictions (Section 3) (CESA 2017; Sherwood 2013; Solar ABCs 2011; SEIA 2019a). ${ }^{34}$ The sale of lower-cost used system equipment for secondary use could increase PV deployment and may help enable access to traditionally underserved market participants such as low-and-moderate income communities (NREL 2019a; SEIA 2019a). ${ }^{35,36}$ Also, industry stakeholders, such as installers; operation and maintenance (O\&M) companies; engineering, procurement and construction (EPC) companies; and reverse logistics companies could expand services to include repair and sale of PV modules and BOS equipment for reuse. New companies, such as Good Sun, EnergyBin, and KinectSolar may also be developed to provide repair/reuse products and services (GoodSun is discussed in Section 6). These companies may provide a suite of services and products that include collection, transport, testing PV equipment to determine reuse potential, repair, installation, resale, and platforms to buy and sell used products (Ludt 2019). ${ }^{37,38}$

PV manufacturers and system owners may receive economic benefits from selling or donating modules and BOS equipment for secondary use. For example, system owners may sell modules that are retired early at lower costs to generate revenue or donate PV modules for charitable use and receive a tax credit (SEIA 2019a; Libby and Shaw 2018). ${ }^{39,40}$ PV manufacturers may also sell operational but blemished modules that are not suited for the primary market to generate revenue, or the manufacturers may donate blemished modules and BOS equipment for a tax benefit (SEIA 2019a; Libby and Shaw 2018). ${ }^{41,42}$ Extracting additional services and revenue from PV modules and BOS equipment increases the total lifetime value of the PV system, and the costs could be shared by primary and secondary users (Salim et al. 2019). Moreover, system owners and PV manufacturers may find it advantageous to sell or donate used modules and BOS equipment to comply with voluntary industry standards or to enhance their corporate responsibility image. ${ }^{43}$ Companies that engage in environmentally sustainable business practices, such as reuse may in turn increase consumer trust, increase consumer confidence in secondary market products, and their overall competitiveness in the marketplace (Xu et al. 2018; Salim et al. 2019).

\footnotetext{
${ }^{30}$ Eric Stikes and Vince Lucia, Good Sun, teleconference, August 26, 2019

${ }^{31}$ Sam Vanderhoof, Recycle PV, teleconference, September 5, 2019

${ }^{32}$ Eric Stikes and Vince Lucia, Good Sun, teleconference, August 26, 2019

${ }^{33}$ Sam Vanderhoof, Recycle PV, teleconference, September 5, 2019

${ }^{34}$ Eric Stikes and Vince Lucia, Good Sun, teleconference, August 26, 2019

${ }^{35}$ Eric Stikes and Vince Lucia, Good Sun, teleconference, August 26, 2019

${ }^{36}$ Sam Vanderhoof, Recycle PV, teleconference, September 5, 2019

${ }^{37}$ Eric Stikes and Vince Lucia, Good Sun, teleconference, August 26, 2019

${ }^{38}$ Sam Vanderhoof, Recycle PV, teleconference, September 5, 2019

${ }^{39}$ Eric Stikes and Vince Lucia, Good Sun, teleconference, August 26, 2019

${ }^{40}$ Sam Vanderhoof, Recycle PV, teleconference, September 5, 2019

${ }^{41}$ Eric Stikes and Vince Lucia, Good Sun, teleconference, August 26, 2019

${ }^{42}$ Sam Vanderhoof, Recycle PV, teleconference, September 5, 2019

${ }^{43}$ Eric Stikes and Vince Lucia, Good Sun, teleconference, August 26, 2019
} 


\subsubsection{Recycling}

Recycling PV system equipment and manufacturing scrap can create new and expanded PV market opportunities, new jobs, and supply chain stability in the United States. Recycling PV modules, BOS equipment, and manufacturing scrap can recover high-value materials that can be sold into commodity markets or be used to manufacture new system equipment (Salim et al. 2019; NREL 2019a; Libby and Shaw 2018; Kalmykova et al. 2018; Xu et al. 2018; Corcelli et al. 2017; Dominguez and Geyer 2017; Weckend, Wade, and Heath 2016; Ghisellini et al. 2016). For example, recycling PV modules and manufacturing scrap can recover materials such as glass, silicon, indium, silver, tellurium and copper (Mulvaney 2019; Heath et al. 2020; Salim et al. 2019; NREL 2019b; SEIA 2019a; Xu et al. 2018; Dominguez and Geyer 2017; Weckend, Wade, and Heath 2016) ${ }^{44}$ Recycling PV BOS equipment, such as the junction box, wires, frame and mounting equipment, can recover copper, aluminum, steel and plastic (Mulvaney 2019; Heath et al. 2020; SEIA 2019a). One estimate found that the value of recovered materials from PV modules, alone, represents a potential $\$ 60$ million U.S. industry by 2030 and a $\$ 2$ billion industry by 2050 (Weckend, Wade, and Heath 2016). The reuse of recovered materials could reduce dependence on foreign imports of raw materials (e.g., silicon, glass necessary for domestic manufacturing needs) and U.S. dependence of imported PV cells, modules, wafers and BOS equipment to meet domestic demand (Sun et al. 2020a; Mints 2020; Smith and Margolis 2019). Moreover, domestic resource recovery could lead to U.S. PV manufacturing opportunities. In addition, third-party recycling companies and lifecycle management companies could expand their services to include resource recovery operations for PV modules and BOS equipment. For example, Cleanlites Recycling Inc. is a universal and electronic waste recycling and waste management company that expanded services to include the collection and recovery of PV modules. ${ }^{45}$ Similar to the reuse market, installers; O\&M companies; EPC companies; and reverse logistics companies (e.g., Verdant Project Management, and HelioPower) are also expanding to offer decommissioning services that include dismantling, handling, transport, recycling and disposal of PV system equipment (CPSC 2020; Ludt 2019). ${ }^{46,47,48}$ New companies, such as Solar Sun Recycling and NuLife, are also emerging to offer reverse logistics, decommissioning, and recycling services.

PV manufacturers, system owners, third-party recyclers, and other industry stakeholders may gain an economic benefit from recycling system equipment. PV manufacturers could lower manufacturing costs by reusing recovered materials from manufacturing scrap, customer warranty returns, and other retired system equipment (Salim 2019; Xu et al. 2018). The reuse of recovered materials could reduce manufacturing costs and could reduce the cost of PV modules and BOS equipment on the primary market (Salim 2019; Xu et al. 2018). PV manufacturers and third-party recyclers may also generate revenue by selling recovered materials into commodity markets (Heath et al. 2020; Salim et al. 2019; Xu et al. 2018; Dominguez and Geyer 2017; NREL 2019b). Similar to the reuse discussion above (Section 2.1.1.1), system owners and PV manufacturers may find it advantageous to recycle system equipment to comply with voluntary industry standards or to enhance their corporate responsibility image (Salim et al. 2019; Xu et al.

\footnotetext{
${ }^{44}$ Parikhit Sinha, First Solar, email, August 26, 2019

${ }^{45}$ Tim Kimmel, Cleanlites Recycling, teleconference, March 5, 2019

${ }^{46}$ Sam Vanderhoof, Recycle PV, teleconference, September 5, 2019

${ }^{47}$ Eric Stikes and Vince Lucia, Good Sun, teleconference, August 26, 2019

${ }^{48}$ Cara Libby, Electrical Power Research Institute, email, January 14, 2021.
} 
2018). ${ }^{49}$ Companies that engage in environmentally sustainable business practices such as recycling may in turn increase consumer trust and their overall competitiveness in the marketplace (Salim et al. 2019; Xu et al. 2018).

\subsubsection{Environmental Drivers}

Environmental drivers, such as reduced negative environmental impacts and resource constraints, may encourage federal, state, and local government investment as well as industry action and private investment in a circular economy for PV system materials in the United States. This section discusses some of those environmental drivers.

Repair/reuse/recycling of PV system equipment and manufacturing scrap presents near-term and future environmental benefits. Repair and maintenance can extend the life of PV equipment and extracting additional services and revenue also increases the total lifetime value of the PV system. Further, extending the useful lifetime of PV equipment through repair and reuse, and recovering PV materials through recycling also lowers lifecycle environmental impacts by reducing energy output, the costs, and environmental pollutants (e.g., greenhouse gas emissions) associated with mining, transporting, refining virgin materials, and manufacturing and distributing new PV products (Salim et al. 2019; Celik et al. 2018; Stolz et al. 2018).

In addition, secondary use of PV system equipment could reduce disposal of reusable products, while resource recovery of modules, BOS equipment (e.g., junction box, wires, frame, mounting equipment), and manufacturing scrap can divert valuable materials, such as silicon, silver, tellurium, cadmium, aluminum, and copper, from landfills (Salim et al. 2019; Mulvaney 2019; $\mathrm{Xu}$ et al. 2018; Dominguez and Geyer 2017; Weckend, Wade, and Heath 2016). For instance, in 2019, copper recovered from manufacturing scrap and discarded copper products accounted for $35 \%$ of the U.S. copper supply (USGS 2020a). In 2019, aluminum purchased from scrap in the United States was about 3.4 million tons, of which about $56 \%$ came from manufacturing scrap and $44 \%$ came from discarded aluminum products (USGS 2020b).

Moreover, repair/reuse/recycling of PV system equipment and manufacturing scrap could alleviate resource constraints and the demand on critical minerals, such as tellurium and aluminum (bauxite) in the United States. The Department of Interior classifies tellurium and aluminum (bauxite) as critical minerals, which are essential to U.S. economic and national security due their necessity in product manufacturing, including use in PV system materials (DOI 2018). ${ }^{50}$ These critical minerals are subject to rising costs due to limited resources and supply chain disruption often caused by political instability in producing regions (DOI 2018). ${ }^{51}$

Repair/reuse/recycling of PV system equipment and manufacturing scrap can support sustainable resource governance by reducing the need to export and mine for virgin minerals often found in countries with less stringent environmental and human health regulations. For example, China maintains the largest tellurium reserves in the world with 6,600 Mt and it produced $290 \mathrm{Mt}$ of refined tellurium in 2019 (USGS 2020c; Mulvaney 2014). In comparison, no tellurium was produced in the United States in 2019 (USGS 2020c).

\footnotetext{
${ }^{49}$ Eric Stikes and Vince Lucia, Good Sun, teleconference, August 26, 2019

${ }^{50}$ Exec. Order No. 13817, 82 Fed. Reg. 60835 (2017)

${ }^{51}$ Exec. Order No. 13817, 82 Fed. Reg. 60835 (2017)
} 


\subsection{Barriers}

Certain factors may inhibit a circular economy for PV system materials in the United States. In this section, we identify technology, process, data, economic, and regulatory factors that may inhibit management decisions and behaviors that facilitate the integration of circularity principles into PV equipment value and supply chains. Table 2 summarizes those barriers.

Table 2. Barriers to a Circular Economy for PV System Materials

\begin{tabular}{|c|c|}
\hline Barrier & Description \\
\hline $\begin{array}{l}\text { Current technology, } \\
\text { infrastructure, and } \\
\text { processes } \\
\text { (Section 2.2.1) }\end{array}$ & $\begin{array}{l}\text { Technology, infrastructure, and processes not optimized for efficient, cost- } \\
\text { effective repair/reuse/recycling of PV system equipment }\end{array}$ \\
\hline $\begin{array}{l}\text { Lack of critical } \\
\text { information and data } \\
\text { (Section 2.2.2) }\end{array}$ & $\begin{array}{l}\text { Limited information and data regarding: the value of, and markets for, } \\
\text { reused PV equipment and recovered PV materials; the volume and } \\
\text { composition of retired PV equipment; the condition and characteristics of } \\
\text { used PV equipment; quality, reliability, safety, and technical viability of } \\
\text { repaired and reused PV equipment; repair/recycling technology, processes, } \\
\text { services; costs; and infrastructure needs }\end{array}$ \\
\hline $\begin{array}{l}\text { Unclear, complex, and } \\
\text { varied laws and } \\
\text { regulations } \\
\text { (Section } 2.2 .3 \text { ) }\end{array}$ & $\begin{array}{l}\text { Laws and regulations applicable to reuse/recycling of PV equipment that are } \\
\text { unclear, complex, vary by jurisdiction, and often require compliance with } \\
\text { stringent handling, storage, transport, treatment, recycling and disposal } \\
\text { requirements that are subject to civil and criminal liability for non-compliance }\end{array}$ \\
\hline $\begin{array}{l}\text { Lack of economic } \\
\text { motivation } \\
\text { (Section } 2.2 .4)\end{array}$ & $\begin{array}{l}\text { Limited economic motivation or incentive to enable collection, transport, and } \\
\text { repair/reuse/recycling of PV system equipment, or to enable the design for } \\
\text { durability, reuse, and recycling }\end{array}$ \\
\hline $\begin{array}{l}\text { Low market confidence } \\
\text { in reused and repaired } \\
\text { PV equipment (Section } \\
\text { 2.2.4) }\end{array}$ & $\begin{array}{l}\text { Inadequate consumer confidence in reused and repaired PV system } \\
\text { equipment to support reuse and repair-for-reuse secondary markets }\end{array}$ \\
\hline
\end{tabular}

\subsubsection{Technology, Infrastructure, and Process Barriers}

Technology, product, and process innovation plays a critical role in efficiency, cost savings, increased profits, and enhanced competitiveness for any industry. Current technology, infrastructure, and processes associated with the repair/reuse of PV modules and recovery of PV module materials are not optimized for efficient, cost-effective reuse or recovery (Salim et al. 2019; Heath et al. 2020; Tura et al. 2018). ${ }^{52}$ This section discusses technology, infrastructure, and process barriers that may inhibit a circular economy for PV system materials, and secondary PV market opportunities in the United States.

Today, there are three main types of PV modules: monocrystalline c-Si, polycrystalline c-Si; and thin-film PV modules, which include amorphous silicon (a-Si), cadmium telluride (CdTe); and copper indium gallium selenide (CIGS) (Heath et al. 2020; Pickerel 2015). Monocrystalline c-Si and polycrystalline c-Si make up more than $90 \%$ of the global PV market (Heath et al. 2020; Pickerel 2015). Although there are only three main types of modules they often vary in size,

\footnotetext{
${ }^{52}$ Sam Vanderhoof, Recycle PV Solar LLC, teleconference, September 5, 2019
} 
design, and composition from manufacturer to manufacturer, and even across different models from the same manufacturer. The variability in module design and composition, along with their design for durability, makes it more difficult to automate disassembly for repair or for resource recovery (Heath et al. 2020).

There is limited infrastructure and no efficient processes in place in the United States to handle the projected volume of early retired and EoL PV equipment. For example, we identified only a handful of companies in the United States that repair or resell used PV modules and BOS equipment for secondary market use. Similarly, although there is a growing number of U.S. based third-party recyclers that accept PV modules anecdotal evidence suggests that collection/sorting sites are limited and that aggregating EoL modules for cost-effective transport is a barrier to recycling (CPUC 2019b; Salim et al. 2019; Libby and Shaw 2018; Heath et al. 2020; First Solar 2019; Good Sun 2019; SEIA 2019b; First Solar 2019; Good Sun 2019; SEIA 2019b). ${ }^{53,54,55,56,57,58}$ In addition, there is no standardized testing process in place to determine the safe and reliable reuse potential of PV modules and BOS equipment, and there is no standardized or automated process to disassemble c-Si PV modules for resource recovery (Heath et al. 2020; CPUC 2019b; ASES 2020). There is also no standardized process in place for the repair of PV modules and BOS equipment. For example, there is evidence that a large number of PV modules deployed worldwide have faulty backsheets - estimates are as high as $10 \mathrm{GW}$ or more (Osborne 2019; Pickerel 2020; Oreski 2020). Although industry is working on technologies to repair backsheets in the field, there is currently no commercialized solution, and there are many unanswered questions with regard to the effectiveness of a proposed solution in terms of safety and reliability, as well as regulatory requirements and legal liability (ASES 2020; CSSA 2020).

Moreover, current PV module recycling technology is not optimized to cost-effectively recover high-purity materials at high recovery rates (Heath et al. 2020). The majority of third-party recycling facilities in the United States that accept PV modules are not designed for module resource recovery, and they process modules through existing metal or glass recycling lines (Heath et al. 2020). Most recycling processes only recover bulk materials from the aluminum frame, external copper wire and glass; and they fail to recover constituents such as silver, copper, silicon, and lead, which constitute most of the potential value of c-Si PV modules (Health et al. 2020). We found only two recyclers in the United States that recover high-purity bulk and trace materials from PV modules_-We Recycle Solar and First Solar (ASES 2020; Heath et al. 2020). First Solar's recycling facilities process only CdTe modules from First Solar customers (Section 6.1) and We Recycle Solar's provisional patent technology processes c-Si and CdTe modules (ASES 2020; Heath et al. 2020; First Solar 2019). ${ }^{59}$ There are efforts to advance PV module

\footnotetext{
${ }^{53}$ It is unclear how many of the recycling facilities identified that accept PV modules process those modules in the United States.

${ }^{54}$ Evelyn Butler, Solar Energy Industries Association, teleconference, February 8, 2019

${ }^{55}$ Matthew Garamone, Environmental Management Services, LLC., and Parikhit Sinha, First Solar, teleconference, March 4, 2019

${ }^{56}$ Matthew Garamone, Environmental Management Services, LLC., and Parikhit Sinha, First Solar, teleconference, August 26, 2019

${ }^{57}$ Eric Stikes and Vince Lucia, Good Sun, teleconference, August 26, 2019

${ }^{58}$ Sam Vanderhoof, Recycle PV Solar LLC, teleconference, September 5, 2019

${ }^{59}$ Matthew Garamone and Parikhit Sinha, First Solar, teleconference, March 4, 2019
} 
recycling in the United States, but none of these efforts are at commercial scale (Heath et al. 2020).

\subsubsection{Information and Data Barriers}

Research and data play an important role in informing investment decisions in the early stages of new and expanded market opportunities, but publicly available research and market information regarding early retired and EoL PV equipment in the United States is limited and variable. This section discusses information and data barriers that may inhibit a circular economy for PV system materials and secondary PV market opportunities in the United States.

Publicly available information about the volume, timing, and condition of early retired and EoL PV equipment is limited (Salim et al. 2019; Heath et al. 2020). For example, the International Renewable Energy Agency (IRENA) and the International Energy Agency (IEA) report is one of the most comprehensive studies to date that estimates the expected volume of EoL PV modules in the United States (Weckend, Wade, and Heath 2016). The IRENA/IEA report found that cumulative U.S. EoL PV modules alone could total one million metric tons (Mt) by 2030 and up to 10 million Mt by 2050 (Weckend, Wade, and Heath 2016). ${ }^{60}$ But a new study using current PV capacity rates and new projection data is overdue. In fact, industry experts warn that the IRENA/IEA EoL projections are lower than the volume they are seeing today and expect to see in the future (CSSA 2020; ASES 2020). Deployment rates are beyond the assumptions used in IRENA/IEA study, projection installation rates are higher than in recent years, and repowering is expected to become more prevalent (Parnell 2020; NREL 2019a; CPUC 2019b; Balfour 2017).

In terms of repowering alone, a Wood MacKenzie report found repowering systems that have reached 20 years of operation could reach $65 \mathrm{GW}$ worldwide by 2030 (Sun et al. 2020a). Moreover, U.S. industry experts are starting to see a large volume of partial and full repowering taking place between 10 and 12 years of operation (ASES 2020; CSSA 2020; NREL 2019a; CPUC 2019b). Experts have identified five main drivers that are prompting PV system owners to repower between 10 and 12 years of operations: (1) low cost, more efficient module technology, (2) power purchase agreement expiration dates, (3) inverter and other equipment replacement in conjunction with a need to comply with more stringent interconnection, fire, building, and equipment regulations (4) early retirements due to extreme weather events (e.g., fire and hail damage) and manufacturer defects, and (5) tax incentives - retrofit investments may qualify for an investment tax credit, a tax deduction through the modified accelerated cost recovery system, and/or a 50\% depreciation bonus (Curtis et al. 2021a; ASES 2020; CSSA 2020; Sun et al. 2020a).

Analysis of, and data on, the true costs of repair/reuse/recycling of PV system equipment is limited. For example, analyses to date have primarily focused on recycling processing costs, and they do not account for disassembly, infrastructure needs (e.g., collection centers or equipment),

${ }^{60}$ These projections are based on an early-loss scenario that includes these assumptions:

- 30-year average PV module lifetime

- $99.99 \%$ probability of loss after 40 years

- $\quad 0.5 \%$ of PV modules reach EoL immediately because of damage during transportation and installation

- $\quad 0.5 \%$ of PV modules reach EoL within 2 years because of faulty installation

- $2 \%$ of PV modules reaching EoL within 10 years

- $4 \%$ of PV modules reaching EoL after 15 years because of technical failures. 
reverse logistics (e.g., sorting, handling, or transport), operating expenses, or regulatory compliance (Salim et al. 2019; Libby and Shaw 2018). These analyses also do not account for innovation in repair/reuse/recycling processes, or PV module technology innovation. Moreover, we found no study that comprehensively analyzes the cost of PV equipment recycling in the U.S. and how that compares to disposal options. Anecdotal evidence suggests that the cost of recycling modules in the United States is often outweighed by cheaper, more accessible disposal options. Some PV recyclers in the United States estimate the cost of processing PV modules ranges from $\$ 15$ to $\$ 45$ per module depending on the pick-up location, module condition, and type of module being recycled (CSSA 2020; ASES 2020). On the other hand, one study found disposal tipping fees at a non-hazardous landfill can cost less than $\$ 1$ per module (\$26/U.S. ton) and less than $\$ 5$ per module at hazardous waste landfills (\$175/U.S. ton) (ASES 2020; CSSA 2020; Ablison Energy 2020; Evergreen Solar 2020; Intermountain Wind \& Solar 2020; CitiGreen, Inc. 2019; Green Coast 2019; Alba Energy 2018; EnergySage 2018; Libby and Shaw 2018). ${ }^{61}$ In addition, we found little data on the processes for (testing for secondary use safety and reliability) or costs related to repair for reuse or direct reuse. We found no study on repair processes or the cost of repair for the U.S. market, but one European study estimated module repair costs between 20 and 90 euros per module (\$23-106 per module based on today's exchange rate) (Tsanakas et al. 2020).

Analysis of, and data on, the value of and markets for repair/reuse/recycling of PV system equipment is also limited. For instance, we found no publicly available study that either comprehensively analyzed the average condition of used PV modules or identified viable secondary use applications. Though the 2016 IEA/IRENA study (Weckend, Wade, and Heath 2016) analyzes the value of recovered materials from EoL PV modules, the study does not take into account the need for material streams of certain purity or loss scenarios of modules not accumulated or recycled. Moreover, the data on the salvage value of and markets for used PV modules that is available is highly variable because of uncertainties regarding the price for newer, more efficient PV modules, repurposing costs, and the lack of degradation data (Salim et al. 2019). Further, we found no publicly available study that considered the recovery value of BOS equipment such as mounting equipment, wires, frames, and junction boxes. There is also limited commodity data for recovered PV system materials, and no projections take into account PV equipment composition or design innovation, or future repair/reuse/recycling technology and process efficiencies.

\subsubsection{Regulatory Barriers}

Federal, state, and local laws and regulations play a critical role in consumer product safety, and reliable electricity service. Laws and regulation also help ensure the safe handling, storage, treatment, and transport of PV modules and BOS equipment. However, state and local interconnection, fire and building, and electric regulations in the United States may directly prohibit the reuse of PV modules and/or BOS equipment for certain grid-tied and off-grid applications. In addition, federal, state, and local laws and regulations mandate costly handling,

\footnotetext{
${ }^{61}$ We calculated the per module disposal cost by estimating a typical module weight of 33-50 pounds (Ablison Energy 2020; Evergreen Solar 2020; Intermountain Wind \& Solar 2020; CitiGreen, Inc. 2019; Green Coast 2019; Alba Energy 2018; EnergySage 2018; Wholesale Solar 2011) and using the per ton landfill tipping costs of \$26/ U.S. ton to $\$ 89 /$ U.S. ton for nonhazardous Subtitle D landfills and \$175/U.S. ton for hazardous Subtitle C landfills provided by (Libby and Shaw 2018).
} 
storage, transport, and treatment requirements for recycling and disposal of PV system equipment that carry civil and criminal penalties for non-compliance. Moreover, federal, state, and local laws and regulations are complex, vary by jurisdiction, and at times are unclear as to how they apply to PV system equipment. This section highlights some regulatory barriers that may inhibit a circular economy for PV system materials and secondary PV market opportunities in the United States.

\subsubsection{Repair/Reuse}

Variable state and local U.S regulations may impact PV system equipment reuse applications and investment in secondary PV markets (Section 3). Most interconnection fire, building, and electric regulations in the United States vary by jurisdiction and may directly prohibit the reuse of PV modules and/or BOS equipment in certain secondary grid-tied and off-grid applications (CESA 2017; IEEE 2018; UL 2010; Lydic 2018; Ardani et al. 2015; NFPA 2019; IBC 2012; Sherwood 2013; Solar ABCs 2011). ${ }^{62}$ Variable regulations applicable to the reuse of PV system equipment may also make it difficult to determine viable secondary markets for PV system equipment, and the uncertainty may stifle consumer confidence in used or refurbished products and overall investment in the repair/reuse of PV system equipment. Beyond our analysis for this report, we found no study that analyzed the impact regulations have on the viability of grid-tied and off-grid secondary use applications for PV modules and BOS equipment. Further, beyond this report, we found no comprehensive study that analyzes the regulatory requirements associated with reuse and repair for reuse of PV modules and BOS equipment.

\subsubsection{Recycling}

Complex, variable, and at times, unclear federal, state, and local U.S. laws and regulations may impact resource recovery of valuable PV system materials (Section 4). End-of-life PV equipment, that is accumulated and/or stored prior to recycling and those being recycled, may be regulated in the same manner as PV equipment accumulated and/or stored prior to disposal and those being disposed of pursuant to the Resource Conservation and Recovery Act of 1976 (RCRA). ${ }^{63}$ RCRA solid waste laws in the U.S. vary by jurisdiction and mandate specific handling, storage, transport, treatment, ${ }^{64}$ recycling, and disposal requirements that carry civil and criminal penalties for violations.

Consideration: If PV equipment, such as modules destined for recycling are regulated in the same manner (same requirements, same legal liability) as PV modules destined for disposal, there may be a lack of motivation to recycle PV modules until the economics of recycling become more competitive with disposal.

\footnotetext{
${ }^{62}$ Eric Stikes and Vince Lucia, Good Sun, teleconference, August 26, 2019

6340 C.F.R. $\S \S 260-265,273$; Universal Waste Rule, 60 Fed. Reg. 25,492, 25,492 (May 11, 1995; to be codified at 40 C.F.R. Parts 9, 260, 261, 262, 264, 265, 266, 268, 270, and 273)

${ }^{64}$ Under RCRA, treatment means "any method, technique, or process, including neutralization, designed to change the physical, chemical, or biological character or composition of any hazardous waste so as to neutralize such waste, or so as to recover energy or material resources from the waste, or so as to render such waste non-hazardous, or less hazardous; safer to transport, store, or dispose of; or amenable for recovery, amenable for storage, or reduced in volume" (40 C.F.R. $\S 260.10)$.
} 
Anecdotal evidence suggests there is confusion about when equipment, such as a PV module becomes a solid waste and subject to RCRA regulation. The point at which a material is considered solid waste determines who the regulated person is, and at what point in the management process RCRA regulation applies. For example, if a PV module is determined to be "solid waste" at the time it is uninstalled then the asset owner would likely be the regulated person with the responsibility and legal liability to comply with RCRA. Alternatively, if the PV module is determined to be "solid waste" later in time after it is uninstalled (because a reuse determination has not yet been made) then the regulated person may be someone other than the asset owner. This regulatory uncertainty could lead to unexpected liability for some PV industry stakeholders (Section 4) (Curtis et al. 2021b; NREL 2019a; CPUC 2019b; DTSC 2019b).

Moreover, there is anecdotal evidence of jurisdictional variability about whether RCRA's household hazardous waste exclusion applies to modules from residential PV systems. If applied, the exclusion would allow EoL modules from residential PV systems to be regulated as nonhazardous solid waste in some U.S. jurisdictions instead of requiring a hazardous waste determination and potentially requiring the management of PV modules as hazardous waste. This regulatory uncertainty could lead to confusion and unexpected liability for some PV industry stakeholders (Section 4.1.2) (Curtis et al. 2021b; NREL 2019a; CPUC 2019b; DTSC 2019b). ${ }^{65,66,67,68,69}$

In addition, if a RCRA regulatory exclusion does not apply, PV equipment may be regulated as hazardous waste if the equipment exhibits one or more hazardous characteristics. There is evidence that c-Si modules tested using the U.S. Environmental Protection Agency's (EPA) approved Toxicity Characteristic Leaching Procedure (TCLP) in some cases exceed allowed toxicity levels for lead, and that those modules were classified and regulated as hazardous waste pursuant to RCRA. However, there have been studies that show that the TCLP results for PV modules are highly variable and may produce different results depending on the sampling location on the module, the method of sample removal, test laboratory conducting the TCLP analysis, among other factors. This variability has created uncertainty about whether the TCLP test is a reliable testing mechanism to determine whether PV modules should be regulated as hazardous waste (which requires more stringent and costly regulatory requirements than nonhazardous solid waste regulation) (Section 4.2) (Curtis et al. 2021b; ASES 2020; CSSA 2020; NREL 2019a; Libby and Shaw 2018). A RCRA hazardous waste classification may also trigger more stringent U.S. Department of Transportation regulation for interstate domestic transport and export of hazardous material (Section 4.5). The cost and liability associated with hazardous waste/hazardous material regulation, coupled with the high cost of PV module recycling compared to disposal may stifle resource recovery in the United States.

\subsubsection{Economic and Market Barriers}

Economic, market, and regulatory uncertainty coupled with legal liability concerns may inhibit secondary PV market opportunities, the recovery of valuable PV system materials, and overall

\footnotetext{
${ }^{65}$ Evelyn Butler, Solar Energy Industries Association, teleconference, February 8, 2019

${ }^{66}$ Matthew Garamone, Environmental Management Services, LLC., and Parikhit Sinha, First Solar, teleconference, March 4, 2019

67 Tim Kimmel, Cleanlites Recycling, teleconference, March 5, 2019

${ }^{68}$ Gary Winslow, MiaSolé, email March 12, 2019

${ }^{69}$ John Martorano, Magnum Computer Recycling, teleconference July 31, 2019
} 
investment in PV products, processes, and services innovation. This section discusses some economic and market barriers that may inhibit a circular economy for PV system material and secondary PV market opportunities in the United States.

Today technology, infrastructure, and processes associated with repair/reuse/recycling of PV system equipment are not optimized for efficient, cost-effective repair/reuse/recovery of valuable materials (Salim et al. 2019; Heath et al. 2020; Tura et al. 2018). The variability in module design and composition, makes it difficult to automate disassembly for repair or resource recovery (Heath et al. 2020). Module backsheet repair is not commercialized and recycling technology is not optimized for cost-effective recover of high-purity materials or high-value materials (e.g., silver, copper, lead). There is also limited infrastructure and no efficient processes in place for repair/reuse/recycling of PV equipment, such as modules. Consequently, collection, sorting, handling, transport, and processing costs for repair/reuse and resource recovery are high. For instances, PV recyclers in the United States estimate the cost recycling at $\$ 15$ to $\$ 45$ per module (which far exceeds the value of recovered materials, approximated at $\$ 2$ per module) while one study found that the cost of disposal at a non-hazardous landfill can cost less than $\$ 1$ per module ( $\$ 26 /$ U.S. ton) and less than $\$ 5$ per module at hazardous waste landfills (\$175/U.S. ton) (Curtis et al. 2021a; ASES 2020; CSSA 2020; Ablison Energy 2020; Evergreen Solar 2020; Intermountain Wind \& Solar 2020; CitiGreen, Inc. 2019; Green Coast 2019; Alba Energy 2018; EnergySage 2018; Libby and Shaw 2018). ${ }^{70}$ As a result, today, there is little evidence of PV equipment reuse and anecdotal evidence suggests that less than $10 \%$ of EoL modules are recycled in the United States (ASES 2020; CSSA 2020).

There is also limited motivation or incentives for private investment in new and expanded PV circular economy market opportunities. For example, there is limited publicly available information and data regarding the true costs of repair/reuse/recycling of PV modules, which take into account disassembly, infrastructure needs (e.g., collection centers or equipment), regulatory compliance, and reverse logistics (e.g., sorting, handling, or transport) (Curtis et al. 2021b). Moreover, there is little data available regarding the value of and markets for reused PV modules and recovered PV materials to inform investment decisions. In addition, state and local interconnection, fire, building, and electric regulations in the United States may directly prohibit the reuse of PV modules and/or BOS equipment for certain grid-tied and off-grid applications. There is also limited publicly available information on projects that demonstrate the quality, performance, safety and technical viability of repaired and reused PV equipment which may impact consumer trust and confidence in secondary market products. Moreover, federal and state solid waste and transportation laws often regulate PV equipment, such as modules destined for resource recovery in the same manner as those destined for disposal, which does not provide an incentive for recycling, especially when the economics and accessibility of disposal are more favorable.

In addition, we did not identify many U.S. federal, state, or local economic incentives or policies that incentivize the repair/reuse/recycling of PV system equipment or early investment in new

\footnotetext{
${ }^{70} \mathrm{We}$ calculated the per module disposal cost by estimating a typical module weight of 33-50 pounds (Ablison Energy 2020; Evergreen Solar 2020; Intermountain Wind \& Solar 2020; CitiGreen, Inc. 2019; Green Coast 2019; Alba Energy 2018; EnergySage 2018; Wholesale Solar 2011) and using the per ton landfill tipping costs of \$26/ U.S. ton to $\$ 89 /$ U.S. ton for nonhazardous Subtitle D landfills and $\$ 175 /$ U.S. ton for hazardous Subtitle C landfills provided by (Libby and Shaw 2018).
} 
and expanded PV markets. Rather, industry stakeholders have commented that newly implemented state regulations may in fact continue to make disposal cheaper and easier than recycling (CSSA 2020; ASES 2020). ${ }^{71}$ For example, industry stakeholders have noted that new universal waste regulations in California, which allow hazardous PV modules to be managed under universal waste regulations may inhibit recycling efforts because they treat disposal and recycling of hazardous PV modules in the same manner (e.g., the same handling, storing, transportation requirements and associated liabilities for non-compliance) (CSSA 2020; ASES 2020). ${ }^{72}$ Given that the costs of recycling hazardous PV modules are higher than the costs of disposal and there are limited facilities that recycle PV modules, disposal may remain the most economically favorable and accessible method for EoL management of discarded hazardous PV modules in California (CSSA 2020; ASES 2020). Notably, New York and North Carolina are considering adopting similar regulations, which would allow hazardous PV modules to be managed as universal waste. ${ }^{73,74}$

\subsection{Enablers}

Certain factors may enable a circular economy for PV system materials in the United States. In this section, we discuss factors that may enable decisions and behaviors that facilitate the repair/reuse/recycling of PV system equipment. Table 3 summarizes those enablers.

Table 3. Enablers to a Circular Economy for PV System Materials

\begin{tabular}{|c|c|}
\hline Enabler & Description \\
\hline $\begin{array}{l}\text { Research, } \\
\text { development, } \\
\text { and analysis } \\
\text { (Section } 2.3 .1 \text { ) }\end{array}$ & $\begin{array}{l}\text { The following could reduce uncertainty and investment risk, inform market } \\
\text { opportunities, and increase consumer confidence: } \\
\text { - R\&D and analysis regarding: } \\
\circ \quad \text { Repowering data } \\
\circ \quad \text { The average condition of retired PV modules } \\
\circ \quad \text { The value of and markets for reused and recovered PV materials } \\
\circ \quad \text { The volume and composition of PV materials } \\
\circ \quad \text { Circular business models } \\
\circ \quad \text { Module design } \\
\circ \quad \text { Reuse/repair/recovery processes and technology } \\
\circ \quad \text { Infrastructure and service needs } \\
\text { - Techno-economic analysis; and } \\
\text { - Technical guidance. }\end{array}$ \\
\hline $\begin{array}{l}\text { Publicly available } \\
\text { information and } \\
\text { information exchange } \\
\text { (Section } 2.3 .2 \text { ) }\end{array}$ & $\begin{array}{l}\text { Information availability and exchange-between manufacturers, owners, } \\
\text { installers, O\&M entities, repair/reuse/recycling companies, logistic companies, } \\
\text { landfill owners/operators, and other PV supply chain actors-could reduce } \\
\text { costs, market and regulatory uncertainty and risk, and increase good faith } \\
\text { relationships between industry stakeholders. }\end{array}$ \\
\hline $\begin{array}{l}\text { Economic incentives } \\
\text { (Section 2.3.3) }\end{array}$ & $\begin{array}{l}\text { Both (1) incentives given to promote collection, transport, and } \\
\text { repair/reuse/recycling of PV system equipment and (2) PV module design for }\end{array}$ \\
\hline
\end{tabular}




\begin{tabular}{ll}
\hline Enabler & Description \\
\hline $\begin{array}{l}\text { Regulatory and Policy } \\
\text { investment by making the economics of early investment more desirable. }\end{array}$ & $\begin{array}{l}\text { Federal and state policies could require or incentivize the collection and } \\
\text { (Section 2.3.4) } \\
\text { repair/reuse/recycling of PV system equipment and manufacturing scrap or } \\
\text { uncertainty and risk associated with PV repair/reuse/recycling activities (e.g., } \\
\text { regulatory requirements under RCRA). In the absence of regulation, global } \\
\text { and national voluntary industry standards (e.g., NSF457) and industry } \\
\text { initiatives (e.g., SEIA's national PV recycling program) could enhance a } \\
\text { company's competitiveness and provide consumer confidence in secondary } \\
\text { market goods. }\end{array}$ \\
\hline
\end{tabular}

\subsubsection{Research, Development, and Analysis Enablers}

$\mathrm{R} \& \mathrm{D}$ and analysis plays a critical role in the design of durable, more easily reused, and recycled PV system equipment, as well as the development of PV reuse/repair/recycling services, business models, and processes. Government funded R\&D and analysis can enable private investment in the early stages of new and expanded PV market opportunities by providing answers to questions that could help alleviate market uncertainty. This section discusses $R \& D$ and analysis factors that may enable reuse/repair/recovery of PV system equipment and secondary market opportunities in the United States.

\subsubsection{Repair/Reuse}

R\&D and analysis regarding the expected volume and timing of retired PV system equipment can provide valuable insight for investment in new and expanded PV markets in the United States. For example, repowering data could aid decommissioning projections, and accurate data regarding the average condition of PV modules (e.g., remaining capacity) when retired could both inform supply projections and help identify viable secondary applications (Salim et al. 2019; Weckend, Wade, and Heath 2016) ${ }^{75,76} \mathrm{R} \& \mathrm{D}$ focused on PV module design for reuse could enable easier reuse (including repair for reuse) and may enable automated diagnostic and safety testing processes, which could improve the economics of secondary use applications.

Analysis that provides comprehensive estimates of (1) the costs of repair/reuse and (2) the resale value of PV system equipment can provide important insight for investors. Cost estimates of reuse and repair for use of PV system equipment could include the costs of sorting, safety and reliability testing, reverse logistics activities, and regulatory compliance. Resale value estimates could include analysis of different PV module and BOS equipment resold into various markets. Resale value estimates of different PV system equipment in various markets, combined with a comprehensive repair/reuse cost estimate, could inform private investment decisions. For example, from April to August 2020, we collected prices of used PV modules on three websites - energybin.com, kinectsolar.com, and greatsolarpanels.com. From the 112 data points collected, we found that the prices for used modules span from $11 \%$ to $114 \%$ of new PV module prices with a mean value of $36 \%$. Moreover, no correlation was found between the price and the module's power output, cell type (poly- or monocrystalline), or origin of the manufacturer. Accordingly, information regarding the actual resale value of used PV equipment, which uses

${ }^{75}$ Sam Vanderhoof, Recycle PV, teleconference, September 5, 2019,

${ }^{76}$ Eric Stikes and Vince Lucia, Good Sun, teleconference, August 26, 2019 
measurable metrics may provide valuable information and insight for secondary market investors. In addition, analysis of the impacts of reuse of PV modules on (1) the overall value of PV system and (2) the primary solar market could also enable investment in secondary market opportunities.

Technical guidance and industry standards for the reuse or repair for use of PV equipment can increase the value of the PV equipment and the overall value of PV system and reduce liability and secondary market uncertainty. For example, technical guidance and industry standards can improve the safety and reliability of in-field repair and repurposed PV modules, which can extend the useful life of the module and PV system. In addition, industry standards may improve consumer confidence in repurposed products and may drive secondary market demand (Salim et al. 2019). ${ }^{77}$ The use of an independent or third-party certification standard guaranteeing the ecofriendliness, safety, and durability of repurposed PV modules may increase re-sale value and improve consumer confidence by lowering the environmental impact of single use modules and could also increase the perceived quality of repurposed modules (Harms et al. 2015). For instance, economic studies have found consumers perceive repurposed products with an ecocertificate (e.g., a certificate indicating that a product has a positive environmental impact) are of higher quality and higher economic value than repurposed products without eco-certificates (Harms et al. 2015). Analysis and guidance on regulatory compliance regarding reuse and repairfor-reuse of PV system equipment could also inform market opportunities and reduce investor risk. For example, guidance on installation, electrical, equipment, building, and fire regulations can inform secondary application options for PV equipment, such as modules (e.g., grid-tied ground mount vs. grid-tied rooftop or off-grid options).

\subsubsection{Recycling}

R\&D and analysis focused on the volume, value of, and markets for recovered PV materials could help alleviate market uncertainty and investor risk in recycling PV equipment in the United States. Research that identifies the current and projected volume of retired PV system equipment in the United States provides insight on the potential supply of recovered materials, while R\&D and analysis focused on the value of and markets for recovered materials informs the potential demand and expected profits (Salim et al. 2019; Heath et al. 2020; Weckend, Wade, and Heath 2016).

Techno-economic analysis that compares recycling methods informs recycling technology needs and the most cost-effective means of recycling. Also, studying the performance of PV modules under diverse conditions, as well as the environmental and economic impacts on various stages of the PV module lifecycle, could provide insight on the impacts of different recycling processes. Evaluating the environmental and economic impact of recycling technologies can guide R\&D needs and ensure maximized benefits and minimized tradeoffs. Techno-economic analysis could also inform the true costs of recycling and could take into account not only disassembly and processing costs but also infrastructure needs (e.g., collection centers and equipment), reverse logistics (e.g., sorting, handling, transport), operating expenses, and regulatory compliance costs (Heath et al. 2020; Salim et al. 2019; Tura et al. 2018; Choi 2017; D’Adamo 2017).

\footnotetext{
${ }^{77}$ Eric Stikes and Vince Lucia, Good Sun, teleconference, August 26, 2019
} 
R\&D and analysis focused on improvements to recycling technology could encourage innovation, improve the overall economics of recycling, and make private investment more desirable. For example, R\&D focused on optimizing cost-effective recovery of high-purity materials at high recovery rates will aid private investment, making the economics more desirable (Heath et al. 2020). R\&D for recycling technology could also consider how new technology designs may be regulated. U.S. regulation is often specific to the recycling processes used and the materials being recycled; as a result, certain recycling processes are regulated more stringently than others. Regulatory analysis can inform how new recycling technology and processes may be regulated, and it can ultimately inform the true cost-effectiveness of a particular recycling technology.

R\&D and analysis focused on recycling infrastructure needs and reverse logistics services and operations could encourage innovation, improve the overall economics of recycling, and make private investment more desirable. Analysis of current recycling infrastructure and compatibility with handling, storage, transport, and recycling PV modules could inform infrastructure, reverse logistic services, and operation needs. For example, some states are partnering with universities and industry stakeholders to study PV module disassembly and separation processes to increase PV recycling efficiencies and alleviate costs and consumer liability concerns (Ehrhard 2019). In addition, geospatial analysis could inform the placement of additional operations and services, such as collection sites and recycling facilities to increase reverse logistics efficiencies.

Similar to the reuse discussion (Section 2.3.1.1), R\&D focused on PV module standardization and design for recycling could enable recycling efficiencies. Innovation in module design and materials composition can enable easier disassembly. PV module design innovation can also lead to automated recycling processes for more efficient module disassembly and resource recovery.

Analysis focused on future PV module designs could provide valuable market insight for recycling PV modules. Understanding potential changes in PV chemistry and design - such as shifting PV cell design from high silver to low silver, high copper content-are important to recycling efforts because they have an impact on the supply and demand of specified materials and the value of those materials in commodity markets. Changes in PV module design may also impact life expectancy analyses and the volume and timing at which PV modules enter the recycling supply chain. Similarly, understanding the evolution of PV module chemistries and designs could inform recycling technology needs (Heath et al. 2020).

Similar to the discussion for reuse (Section 2.3.1.1), technical guidance and industry-led initiatives and standards for recycling PV modules can increase safe handling, transport and storage of PV modules and reduce liability concerns. In addition, analysis and guidance on federal state, and local regulatory compliance can reduce regulatory uncertainty and risk associated with non-compliance.

\subsubsection{Information Availability and Exchange Enablers}

Information availability and exchange can play an important role in facilitating repair/reuse/recycling of PV system equipment. Increasing the amount of information available to - and the exchange of information among - solar industry stakeholders regarding PV system equipment may enable repair/reuse/recycling and new and expanded market opportunities in the 
United States. This section discusses information availability and exchange factors that may enable repair/reuse/recycling of PV modules in the United States.

Reliable information on the makeup and the concentration of materials in a given PV panel model could reduce the costs and liabilities associated with repair/reuse/recycling efforts (Salim et al. 2019; NREL 2019a; Tura et al. 2018; Besiou and Van Wassenhove 2016). Labeling requirements could enable information exchange between manufacturers and decommissioned PV management stakeholders and secondary market entrepreneurs that can inform the safe handling, transport, storage, and repair/reuse/recycling of decommissioned modules and BOS equipment (Salim et al. 2019). Such information exchange could also act as a stopgap measure for manufacturers that go out of business before a module is decommissioned (Salim et al. 2019; PSI 2018). Moreover, such shared knowledge could also eliminate the need to conduct expensive and variable testing (e.g., TCLP testing; Section 4.1.3) that may be required to determine whether EoL PV modules are hazardous solid waste (Libby and Shaw 2018). In addition, transparent information exchange can strengthen relationships between different solar industry stakeholders (Curtis et al. 2021b; Salim et al. 2019).

\subsubsection{Economic Enablers}

New and expanded market opportunities may encourage federal, state, and local government investment in the repair/reuse/recycling of PV system equipment. Cost savings, increased profits, and enhanced competitiveness play a critical role in private sector investment for new and expanded market opportunities for repair/reuse/recovery of PV system equipment. Policies can encourage repair/reuse/recycling and enable private industry investment in new and expanded PV market opportunities through financial incentives. This section discusses some economic enablers that may support repair/reuse/recycling of PV system equipment and secondary PV market opportunities in the United States.

Federal and state government economic incentives could enable private industry investment in PV repair/reuse/recycling markets by making the economics of early market investment more desirable (Salim et al. 2019). Federal and state government subsidies, grants, or awards to support new repair/reuse/recycling companies or incumbent industry providers seeking to expand their services to include direct repair/reuse/recycling operations could help encourage private investment by reducing investment risk. For example, increased grant funding to expand the collection of data - such as the viability of used modules for resale, the costs of materials procurement, handling, and operational expenses of repair/reuse/recycling companies, and the quantity and pricing of used modules - could result in more empirical research and support for a strong secondary PV market (Good Sun 2019). Similarly, direct federal or state funding for R\&D could encourage innovation in the design for more durable, standardized PV products, which could increase reuse application, secondary market opportunities for PV equipment, and recycling efficiencies. Business or tax incentives for R\&D and analysis as well as repair/reuse/recycling companies could help solar industry stakeholders overcome current secondary market investment and resource recovery uncertainties (Salim et al. 2019). For example, industry experts have observed that solar industry stakeholders who donate PV modules for reuse and repair for reuse may be eligible for a tax credit (Good Sun 2019). ${ }^{78}$

\footnotetext{
${ }^{78}$ Eric Stikes and Vince Lucia, Good Sun, teleconference, August 26, 2019
} 


\subsubsection{Regulatory and Policy Enablers}

Federal, state, and local laws and regulations play a critical role in consumer product safety and reliable electricity service. Laws and regulation may also help ensure the safe handling, storage, treatment, transport, repair/reuse/recycling, and disposal of PV equipment. Policy can also mandate or incentivize repair and reuse of PV equipment and the recovery of PV system materials and help enable a circular economy for PV system materials. Industry standards, in the absence of regulation, can also provide guidance for environmentally sustainable management decisions and behaviors for PV system equipment. This section discusses some regulatory and policy factors that may support repair/reuse/recycling of PV system equipment and secondary PV market opportunities in the United States.

\subsubsection{Repair/Reuse}

Clear and consistent federal, state, and local laws and regulations regarding the repair/reuse of PV system equipment could reduce regulatory uncertainty, liability concerns, and overall investor risk. Interconnection, fire, building, and electrical regulations that specifically address the reuse of PV system equipment could enable safe and reliable installation for reuse, help identify viable secondary use applications, and increase consumer confidence in the reuse of PV system equipment. In addition, consistent regulations across U.S. jurisdictions could reduce regulatory complexities, soft costs, and legal liability associated with regulatory compliance (Lydic 2018; CESA 2017).

Policies that mandate or incentivize repair/reuse of PV system equipment could also enable a circular economy for PV system materials. For example, federal and state regulations that prohibit disposal of $\mathrm{PV}$ modules or require reuse of PV modules could enable sustainable management decisions and behaviors and make early investment in reuse of PV modules more desirable. For instances, Washington State has a policy in place that will require PV manufacturers to takeback and reuse or recycle PV modules, at no cost to owners (Section 5.1.1). ${ }^{79}$

Finally, industry standards can also provide guidance in the absence of regulation. Development of a standard similar to the Underwriters Laboratories (UL) 1974 standard, which addresses the safety and reliability of repurposed batteries, could be useful to the solar industry for the secondary use of PV modules and inverters (UL 2019). Reliability and safety guidance for testing used modules and the installation of used modules for secondary application could reduce liability concerns and improve consumer confidence in secondary use products.

\subsubsection{Recycling}

Clear and consistent federal, state, and local laws and regulations regarding resource recovery of PV system materials could reduce regulatory uncertainty, liability concerns, and overall investor risk. For example, clarity and guidance regarding when PV equipment becomes a "solid waste" and subject to RCRA regulation could reduce regulatory uncertainty and liability concerns. Similarly, guidance on other regulatory schemes such as U.S. Department of Transportation regulations and their applicability to EoL PV modules could also inform the true costs of recycling modules. In addition, consistent regulations across U.S. jurisdictions could

\footnotetext{
${ }^{79}$ Wash. Rev. Code $\S 70$ A.510.010(5)
} 
reduce regulatory complexities, soft costs and legal liability associated with regulatory compliance.

Similar to the reuse discussion in the previous section (Section 2.3.4.1), policies that mandate or incentivize recycling PV modules can also enable a circular economy for PV system materials. For example, federal and state regulations that prohibit disposal of PV modules, provide an exemption from stringent regulation, or require recycling of PV modules could enable sustainable management decisions and behaviors and make the economics of recycling more competitive with disposal. For instances, Washington State's law also reduces the legal and financial burden on PV manufacturers that takeback and recycle modules by allowing those modules to be regulated under less-stringent solid waste requirements then material being disposed of (5.1.1) (WSDE 2007).

Consideration: Certain materials such as lead-acid batteries are subject to less stringent RCRA regulation when recycled. Specifically, "persons who generate, transport, regenerate, collect, and store spent lead-acid batteries before reclamation, but do not perform the actual reclamation," are excluded from RCRA regulations. ${ }^{80} \mathrm{~A}$ similar exclusion from RCRA regulation for PV modules could encourage recycling PV modules, especially given current market conditions which favor disposal.

In the absence of regulation, voluntary industry standards and industry-led initiatives may also encourage environmentally sustainable materials management decisions and behaviors for EoL PV equipment (Tura et al. 2019; Bai et al. 2015; Dong et al. 2016). For example, NSF/ANSI 457 (Sustainable Leadership Standard for Photovoltaic Modules and Photovoltaic Inverters) establishes certification requirements that are focused on sustainable performance criteria that include EoL management and design for recycling. More standards like this, in the absence of federal and state regulation, could enable recycling of PV equipment. Similarly, the Solar Energy Industries Association (SEIA) launched a National PV Recycling Program that aggregates services of recycling vendors and PV manufacturers to form a network of preferred partners that can cost-effectively recycle decommissioned PV modules (SEIA 2019c; SEIA 2019b; CPUC 2019b). Industry-led initiatives such as SEIA's National PV Recycling Program can enable recycling of PV modules by making it easier for stakeholders to find a company to responsibly manage their decommissioned PV modules (SEIA 2019b).

\section{Regulatory Considerations for Reuse of PV System Equipment}

In this section, we discuss state and local regulations that may impact the installation and interconnection of used PV system equipment in the United States. Table 4 summarizes those regulations. Unless otherwise specified, in this section "reuse" refers to direct reuse of PV equipment and does not include repair for reuse.

8040 C.F.R. $\S 266.80$ 
Table 4. Regulatory Considerations for Reuse of PV System Equipment

\begin{tabular}{ll}
\hline $\begin{array}{l}\text { Regulatory } \\
\text { Consideration }\end{array}$ & Description \\
\hline $\begin{array}{l}\text { Interconnection } \\
\text { regulations } \\
\text { (Section 3.1) }\end{array}$ & $\begin{array}{l}\text { State and local regulations that govern how PV systems connect to the electric } \\
\text { grid, which may restrict the reuse of PV equipment in certain grid-tied } \\
\text { applications }\end{array}$ \\
\hline $\begin{array}{l}\text { Fire and } \\
\text { building regulations } \\
\text { (Section 3.2) }\end{array}$ & $\begin{array}{l}\text { State and local regulations that govern the design, materials, and quality of } \\
\text { buildings and structures that connect to PV systems, which may restrict the reuse } \\
\text { of PV equipment in certain grid-tied and off-grid applications }\end{array}$ \\
\hline $\begin{array}{l}\text { Electrical } \\
\text { regulations }\end{array}$ & $\begin{array}{l}\text { State and local regulations that govern electrical safety, design, installation, and } \\
\text { (Section 3.3) }\end{array}$ \\
\hline
\end{tabular}

\subsection{Interconnection Regulations}

Solar industry stakeholders may want to consider state and local interconnection regulations that impact the reuse of PV system equipment in certain grid-tied applications. Jurisdictional interconnection regulations consist of legal requirements and procedures that regulate the design and quality of PV system electrical equipment and govern how electric utilities, independent power producers, and consumers connect PV systems to the electric grid (CESA 2017).

Interconnection regulations are complex, and vary by jurisdiction (e.g., locality by locality and state by state) (CESA 2017). Most interconnection regulations fall under the jurisdiction of state public utility commissions, but cities with municipal utilities may also influence interconnection regulations in their jurisdictions (CESA 2017; Ardani et al. 2015). In developing interconnection regulations, most jurisdictions in the United States have adopted the Institute of Electrical and Electronics Engineers (IEEE) equipment standards, which reference and may be used in conjunction with UL testing standards - both of which are international voluntary industry standards (DOE 2011).

State and local interconnection regulations may directly impact the reuse of PV modules and BOS equipment that are out of compliance with equipment standard requirements (CESA 2017; Ardani et al. 2015). Many jurisdictions have incorporated model industry standards, such as IEEE 1547 Standard $^{81}$ and UL 1741 Standard, ${ }^{82}$ as regulatory requirements. IEEE 1547 Standard provides technical specifications ${ }^{83}$ for PV systems to interconnect to the electric grid (IEEE 2018; Lydic 2018). UL 1741 requires that PV systems use smart inverters for grid-tied applications (UL 2010; Lydic 2018). Therefore, in jurisdictions that have adopted the IEEE 1547 Standard or the UL 1741 Standard, interconnection regulations may effectively prohibit the reuse of PV modules for grid-tied rooftop, building-mounted or ground-mounted applications if they are not compatible with smart inverters or are otherwise out of compliance with applicable

\footnotetext{
${ }^{81}$ IEEE 1547 Standard for Interconnection and Interoperability of Distributed Energy Resources with Associated Electric Power System Interfaces (IEEE 2018).

${ }^{82}$ UL 1741 Inverters, Converters, Controllers, and Interconnection System Equipment for Use with Distributed Energy Sources (UL 2010).

${ }^{83}$ IEEE 1547 Standard requires that inverter-based distributed energy resources, such as PV systems use "smart inverters" to provide grid support functions, such as increasing the amount of distributed energy resources that can be accommodated on the grid and increasing the quality of power provided (IEEE 2018; Lydic 2018).
} 
equipment regulations (IEEE 2018; UL 2010; Lydic 2018; CESA 2017). There is also evidence that regional distributors are selling legacy inverters - which are still under warranty-for gridtied applications in jurisdictions that have not adopted the IEEE 1547 and UL 1741 standards (Schmid 2020).

Example: In 2017, California revised Electric Rule 21, a tariff that requires that new utility PV systems use "smart" inverters, in compliance with testing protocol UL 1741 Standard, to communicate effectively over the internet and use other advanced inverter functions (UL 2010; CPUC 2019a). Other jurisdictions, including ISO New England ${ }^{84}$ and Hawaii have also adopted UL 1741 Standard and IEEE 1547 Standard into their interconnection regulations. In these jurisdictions, older PV modules that are not compatible with smart inverters or do not otherwise comply with the UL 1741 and IEEE 1547 standards may not be connected to the utility's distribution system (CPUC 2019a). ${ }^{85}$

\subsection{Fire and Building Regulations}

Solar industry stakeholders may want to consider state and local fire and building regulations that may impact the reuse of PV system equipment in certain grid-tied and off-grid applications. Fire and building regulations are jurisdictional requirements that incorporate UL model testing standards used to grade and classify the fire resistance of roof coverings (e.g., shingles) and rooftop electrical installations (e.g., rooftop PV systems) (NFPA 2019; IBC 2012).

Fire and building regulations are complex, and vary by jurisdiction (e.g., locality by locality and state by state). Though fire regulations are not consistent across the United States, 42 states have adopted some version of the International Code Council's International Fire Code (IFC). The IFC is a voluntary industry standard, the purpose of which is to reduce the possibility of fire and mitigate fire damage to building structures (CESA 2017). In addition, all 50 states and all U.S. territories have adopted, as a regulatory requirement, some version of the International Code Council's International Building Code (IBC) — an international model industry standard that promotes safe building practices to provide safeguards from hazards associated with the built environment (ICC 2018).

Fire and building regulations may directly impact the reuse of PV modules and BOS equipment for rooftop and building mounted grid-tied and off-grid applications, if the fire classification of the entire PV system - including the module and mounting system - does not match the fire classification of the roof covering (e.g., shingles) (CESA 2017; Sherwood 2013; Solar ABCs 2011). ${ }^{86}$ Roof-mounted PV systems and roof coverings may be classified as A, B, or C depending on an evaluation of their flammability characteristics pursuant to UL testing standards. UL 1703 Standard, which has been incorporated into the IFC and IBC, provides the basis for designating roof-mounted PV systems as Class A, B, or C depending on an evaluation of their flammability characteristics (UL 2013; NFPA 2019; IBC 2012). ${ }^{87}$ Correspondingly, UL

\footnotetext{
${ }^{84}$ ISO New England is an independent nonprofit regional transmission organization that serves Connecticut, Maine, Massachusetts, New Hampshire, Rhode Island, and Vermont by overseeing the operation of New England's bulk electrical power system and transmission lines (ISO New England 2020).

${ }^{85}$ Eric Stikes and Vince Lucia, Good Sun, teleconference, August 26, 2019

${ }^{86}$ Eric Stikes and Vince Lucia, Good Sun, teleconference, August 26, 2019

${ }^{87}$ Under a previous version of UL 1703 Standard, the fire classification rating system only applied to PV modules, not the entire PV system. In 2013, UL 1703 was revised to incorporate the entire PV system, including the module and mounting system (UL 2013).
} 
790 Standard, which has been incorporated into the IFC and IBC, provides the basis for designating roof coverings as Class $\mathrm{A}, \mathrm{B}$, or $\mathrm{C}$ depending on their flammability characteristics (UL 2004; NFPA 2019; IBC 2012). Roof-mounted PV systems and roof coverings designated as Class A are the most fire resistant (UL 2013; UL 2004). In 2012, the IBC was updated to incorporate Section 1509.7.2, which requires that roof-mounted PV systems have the same fire classification (or a higher rating) as the roof coverings to which they are attached (IBC 2012). Accordingly, in jurisdictions that have adopted IBC Section 1509.7.2, fire and building regulations may effectively prohibit the reuse of PV modules and BOS equipment if they cause the fire classification of the entire roof-mounted PV system to drop to a lower classification than the roof covering (IEEE 2018; UL 2010; Lydic 2018, CESA 2017).

Consideration: In response to threats from wildfires, many jurisdictions, such as California, have increased fire classification rating requirements for roof coverings to Class $A$ in high-risk fire areas (Sherwood 2013). Therefore, many older PV modules and BOS equipment designated as Class B or $\mathrm{C}$, may be prohibited for reuse for grid-tied and off-grid roof-top PV system applications in jurisdictions where Class A roof coverings are required (CESA 2017; Sherwood 2013; Solar ABCs 2011). ${ }^{88}$

\subsection{Electrical Regulations}

Solar industry stakeholders may want to consider state and local electrical regulations that impact the reuse of PV system equipment in certain grid-tied and off-grid applications. Electrical regulations are jurisdictional requirements that govern PV system electrical equipment for gridtied and off-grid applications (CESA 2017).

Electrical regulations are complex and vary by jurisdiction (e.g., locality by locality and state by state). Electrical regulations contain provisions that govern electrical equipment, including installation requirements. For example, electrical regulations may require the installation of certain equipment such as rapid shutdown devices that are needed to protect installers or first responders from electrical shock (CESA 2017). Though electrical regulations are not consistent across the United States, 46 states have adopted some version of the National Fire Protection Association's (NFPA) National Electrical Code (NEC), which provides electrical installation standards to minimize risks associated with the use of electricity. Some states leave the adoption of electrical regulations to local jurisdictions and have not adopted electrical regulations on a statewide level (CESA 2017).

Electrical regulations may directly prohibit the reuse of PV modules and BOS equipment for certain grid-tied and off-grid applications if the PV module or BOS equipment is out of compliance with industry equipment regulations enacted by a jurisdiction. For example, pursuant to NEC Section 690.12, PV system circuits installed on buildings must contain rapid shutdown devices to reduce the risk of electrical shock to first responders in emergency situations (NEC 2014). In 2017, NFPA updated NEC Section 690.12, which changed the design and technology requirements for rapid shutdown devices on PV systems (NEC 2014). Accordingly, older PV equipment that is not compatible with updated rapid shutdown devices may be prohibited from rooftop and building-mounted grid-tied and off-grid applications in states that have adopted the

${ }^{88}$ Eric Stikes and Vince Lucia, Good Sun, teleconference, August 26, 2019 
new rapid shutdown provisions of NEC Section 690.12 (CESA 2017) ${ }^{89}$ In addition, states that have adopted the new rapid shutdown provisions of NEC Section 690.12 have not consistently enforced the provisions, leading to inconsistent compliance with NEC Section 690.12 in the United States (CESA 2017).

\section{Statutory and Regulatory Considerations for Reuse, Recycling, and Disposal of PV System Equipment}

In this section, we discuss U.S. federal, state, and local solid waste, hazardous waste, and universal waste statutory and regulatory requirements that may apply to recycling and disposal of PV equipment and manufacturing scrap. This section also discusses hazardous material domestic transport regulations and hazardous waste regulations that may apply to PV equipment transported or exported for reuse, resource recovery, or disposal. Unless otherwise specified, in this section "reuse" refers to both direct reuse and repair for reuse of PV equipment. Table 5 summarizes those regulations.

Table 5. Regulatory Considerations for the Reuse, Recycling, and Disposal of PV System Equipment

\begin{tabular}{|c|c|c|}
\hline $\begin{array}{l}\text { Regulatory } \\
\text { Consideration }\end{array}$ & Description & Application \\
\hline $\begin{array}{l}\text { Solid waste laws and } \\
\text { regulations } \\
\text { (Section 4.1) }\end{array}$ & $\begin{array}{l}\text { Mandatory requirements that vary across jurisdictions, which } \\
\text { govern the generation, handling, storage, transport, } \\
\text { treatment, recycling, and disposal of non-hazardous solid } \\
\text { wastes, which may include PV equipment and manufacturing } \\
\text { scrap accumulated or stored before recycling, or disposal } \\
\text { and those being recycled or disposed of }\end{array}$ & $\begin{array}{l}\text { Recycle, } \\
\text { disposal }\end{array}$ \\
\hline $\begin{array}{l}\text { Hazardous waste } \\
\text { laws and regulations } \\
\text { (Section } 4.2 \text { ) }\end{array}$ & $\begin{array}{l}\text { Mandatory requirements that vary across jurisdictions, which } \\
\text { govern the generation, handling, storage, transport, } \\
\text { treatment, recycling, and disposal of hazardous wastes, } \\
\text { which may include PV equipment accumulated or stored } \\
\text { before recycling, or disposal and those being recycled or } \\
\text { disposed of. Hazardous waste requirements are more } \\
\text { stringent than non-hazardous solid waste requirements. }\end{array}$ & $\begin{array}{l}\text { Recycle, } \\
\text { disposal }\end{array}$ \\
\hline $\begin{array}{l}\text { Universal hazardous } \\
\text { waste laws and } \\
\text { regulations (Section } \\
\text { 4.3) }\end{array}$ & $\begin{array}{l}\text { Optional alternative hazardous waste requirements that vary } \\
\text { across jurisdictions, which govern the generation, handling, } \\
\text { storage, treatment, transport, recycling, and disposal of } \\
\text { specified types of waste, which may include PV modules } \\
\text { accumulated or stored before recycling, or disposal, and } \\
\text { those being recycled or disposed of. Universal hazardous } \\
\text { waste requirements are a subset of-and are less stringent } \\
\text { than-hazardous waste requirements, but more stringent } \\
\text { than non-hazardous solid waste requirements. }\end{array}$ & $\begin{array}{l}\text { Recycle, } \\
\text { disposal }\end{array}$ \\
\hline $\begin{array}{l}\text { Hazardous materials } \\
\text { transportation } \\
\text { regulations } \\
\text { (Section } 4.5 \text { ) }\end{array}$ & $\begin{array}{l}\text { Mandatory requirements that govern U.S. interstate } \\
\text { commerce shipping and transport of hazardous materials, } \\
\text { which may include PV equipment being shipped or } \\
\text { transported across state lines for reuse, recycling, or } \\
\text { disposal }\end{array}$ & $\begin{array}{l}\text { Reuse, } \\
\text { recycle, } \\
\text { disposal }\end{array}$ \\
\hline
\end{tabular}

${ }^{89}$ Eric Stikes and Vince Lucia, Good Sun, teleconference, August 26, 2019 


\section{Regulatory Consideration \\ Description \\ Application}

Hazardous waste export regulations (Section 4.5.4)
Mandatory requirements that govern the export, shipping, and transport of hazardous materials to other countries, which may include PV equipment being exported, shipped, or transported for reuse, recycling, or disposal
Reuse, recycle, disposal

\subsection{Regulation of PV System Equipment as Solid Waste}

Decommissioned PV modules and BOS equipment that are discarded and not directly reused may be subject to U.S. federal, state, and/or local solid waste requirements pursuant to the Resource Conservation and Recovery Act of 1976 (RCRA). ${ }^{90,91}$ In relevant part, RCRA defines "solid waste" to include "...other discarded material.", 92 RCRA regulations define "discarded material" to include materials "disposed of," "burned or incinerated," "recycled," or "accumulated, stored, or treated before or in lieu of being recycled or disposed of." 93 By this definition, EoL PV modules and BOS equipment accumulated or stored before recycling and those being recycled or disposed of may be regulated as solid waste pursuant to RCRA.

Subtitle D of RCRA grants authority to states to regulate non-hazardous solid waste pursuant to federal guidelines that set minimum standards for the operation of state and local management of solid waste. ${ }^{94}$ However, states have the authority to set more stringent requirements than the federal standards and to define what constitutes solid waste in their own regulations. ${ }^{95}$ States may also delegate regulatory authority to local governments (EPA 2019d). Accordingly, the types of materials that qualify as "solid waste" may vary across jurisdictions.

The person that determines that PV equipment, such as a module, is "discarded material" has the responsibility and potential legal liability to determine if the EoL PV module is a "solid waste" in their state or local jurisdiction. Anecdotal evidence suggestions that there is confusion about when PV equipment, such as a PV module becomes a solid waste and subject to RCRA regulation. ${ }^{96}$ The point at which a material is considered solid waste determines who the regulated person is, and at what point in the management process RCRA regulation applies. For instance, if a PV module is determined to be "solid waste" at the time it is uninstalled then the asset owner would likely be the regulated person with the responsibility and legal liability to comply with RCRA. In comparison, if a PV module is determined to be "solid waste" later in time after it is uninstalled (because a determination of the module's reuse potential has not yet been made) then the regulated person may be someone other than the asset owner and RCRA compliance may not be triggered until after subsequent handling, transport, or storage. Some states are working to clarify when PV modules are considered solid waste. For example, in California, the Department of Toxic Substances Control released guidance noting that discarded

\footnotetext{
9042 U.S.C. $\S 6903(27)$

9140 C.F.R. $\$ 261.2(\mathrm{e})$

9242 U.S.C. $\$ 6903(27)$

9340 C.F.R. $\S \S 261.2(\mathrm{a})-(\mathrm{c}) ; 42$ U.S.C. $\S 6903(27) ; 40$ C.F.R. $\S 261.2(\mathrm{e})(\mathrm{ii})$

9442 U.S.C. $§ 6941 ; 40$ C.F.R. $\S \S 239-259$

9542 U.S.C. $\$ 6941 ; 40$ C.F.R. $\$ \S 239-259$

96 The issue of when a material becomes a solid waste is not unique to PV and has generally been a point of confusion regarding RCRA regulation (Curtis et. al. 2021; Broun and O'Reilly 2019; Gaba 2008; EPA 2005; Johnson 1991; Gaba 1989).
} 
PV modules (e.g., PV modules that are abandoned, relinquished, or recycled) are considered solid waste when they are disconnected or removed from service, which may prompt a reuse determination to be done on site (DTSC n.d.).

When a person determines that PV equipment, such as a module, is discarded (e.g., constitutes a solid waste), they become a regulated entity (known as a generator under RCRA) ${ }^{97}$ and may be subject to federal, state, and/or local RCRA solid and hazardous waste regulations, unless an exclusion applies. For example, in certain circumstances, discarded PV equipment may be excluded from solid waste regulations if they are recycled ${ }^{98}$ (Section 4.1.1). In addition, discarded PV equipment, such as modules, may be excluded from the solid and hazardous waste regulations if they constitute household waste ${ }^{99}$ (Section 4.1.2). If an exclusion from the solid or hazardous waste regulations does not apply, then the generator must make a hazardous waste determination ${ }^{100}$ (Section 4.1.3). Discarded PV equipment, such as a module that exhibits hazardous characteristics (e.g., toxicity) are subject to mandatory jurisdictional hazardous waste requirements (Section 4.2). If the generator determines that discarded PV equipment is not hazardous, the generator must comply with applicable non-hazardous solid waste regulations.

\subsubsection{Materials Excluded from the Definition of Solid Waste}

Certain PV system equipment and manufacturing scrap may be excluded from the definition of solid waste and RCRA federal hazardous waste regulation (in some U.S. jurisdictions) if they are recycled. ${ }^{101}$ Exclusions under RCRA are specific to the type of materials being recycled, the recycling processes used, and how the recovered resources are used. Examples of federal exclusions that could potentially apply to recycling PV system equipment include:

- Scrap metal, including processed scrap metal, unprocessed home scrap metal, and unprocessed "prompt" scrap metal that is being recycled. ${ }^{102}$ For example, metal frames from PV system modules and ballasts.

- Hazardous secondary material ${ }^{103}$ that is:

- Generated and legitimately reclaimed within the United States or its territories that is under the control of the generator, provided certain regulatory requirements are met. ${ }^{104}$ For example, a PV module manufacturer that has an on-site recycling facility attached to their manufacturing operations.

- Generated and then transferred for reclamation, provided certain regulatory requirements are met ${ }^{105}$

- Exported from the United States and reclaimed at a reclamation facility in another country, provided certain regulatory requirements are met ${ }^{106}$

\footnotetext{
9740 C.F.R. $\$ 273.9$

9840 C.F.R. $\S 261.4$ (a)

9940 C.F.R. $\S 261.4(b)$

10040 C.F.R. $\S \S 261.3(\mathrm{a})(2) ; 261.10,261.20-.24 ; 262.11$

10140 C.F.R. $\$ 261.4$ (a)

10240 C.F.R. $\S 261.4(a)(13)$

${ }^{103}$ A "hazardous secondary material" is a material that requires reclamation before reuse and that when discarded (which may include recycling) would be identified as a hazardous waste (40 C.F.R. $§ 260.10$; EPA 2014).

10440 C.F.R. $\S 261.4(\mathrm{a})(23)$

10540 C.F.R. $\$ 261.4(\mathrm{a})(24)$

10640 C.F.R. $\S 261.4(\mathrm{a})(25)$
} 
To meet any of the hazardous secondary material exclusions from RCRA, the person who generates the hazardous secondary material and the recycler must ensure the:

- Hazardous secondary material is managed as a valuable commodity when it is under their control

- Hazardous secondary material provides a useful contribution to the recycling process or to a product or intermediate recycling process

- Recycling process produces a valuable product or intermediate

- Recycled product is comparable to products in the same category. ${ }^{107}$

Consideration: The EPA may authorize states and U.S. territories to administer a hazardous waste program in lieu of the federal program (EPA 2019d; EPA 2019e). ${ }^{108}$ State-administered hazardous waste programs are required by federal law to be at least as stringent as RCRA, but they may include requirements beyond federal requirements (EPA 2019d; EPA 2019e). As a result, states with authority to administer a hazardous waste program may choose to adopt or not adopt the federal exclusions above.

\subsubsection{Materials Excluded from the Definition of Hazardous Solid Waste}

Residential PV system equipment that is considered solid waste may be excluded from the definition of hazardous solid waste and RCRA hazardous waste regulations in some U.S. jurisdictions. ${ }^{109}$ EPA regulations exclude household solid waste from the definition of hazardous solid waste and RCRA hazardous regulation. Household solid waste (HHW) is defined in relevant part as "garbage, trash, sanitary waste, and waste generated from routine house and yard maintenance) derived from households - including single and multiple residences, hotels and motels, bunkhouses, ranger stations, crew quarters, campgrounds, picnic grounds, and day-use recreation areas" (EPA 2020a). ${ }^{110}$ EPA guidance states that the "household hazardous waste exclusion extends to house wastes accumulated in quantities that would otherwise be regulated or when transported, stored, treated, disposed, recovered, or reused at collection centers." The guidance also promotes reuse and recycling over disposal (EPA n.d.; EPA 1988). To be excluded from federal hazardous waste requirements, HHW must meet two requirements:

- The waste must be generated by individuals on the premise of a temporary or permanent residence.

- The waste stream must be composed primarily of materials found in wastes generated by consumers in their homes (EPA 2020a).

Consideration: In 2019, the California Energy Commission passed a measure requiring all newly constructed single-family residences, and multifamily buildings in California to have a PV system installed as an electricity source. ${ }^{111}$ There is evidence of efforts to propose similar legislation by mid2022 in ten additional states-Nevada, Colorado, New Mexico, Texas, Minnesota, Michigan, North Carolina, Maryland, Pennsylvania, and Massachusetts (Driscoll 2020).

\footnotetext{
10740 C.F.R. $\S 260.43$

${ }^{108}$ All 50 states and all U.S. territories have the option to administer a hazardous waste program under RCRA (EPA 2019d EPA 2019e). However, Alaska, Iowa, Puerto Rico, and the U.S. Virgin Islands do not have an EPAapproved hazardous waste program (EPA 2019d; EPA 2019e).

10940 C.F.R. $\S 261.4($ b)

11040 C.F.R. $\$ 261.4($ b)(1)

${ }^{111}$ Cal. Code Regs. tit. 24, $\S \S 110.10$ (2019)
} 
There is anecdotal evidence of conflicting jurisdictional views on the applicability of the HHW exclusion as it applies to residential PV systems. The debate centers around two issues (1) whether residential PV system equipment meet the requirements of the HHW exclusion outlined above, and (2) whether the exclusion stays with the waste or the generator - i.e., whether thirdparty entities collecting HHW handling, transport, storage, recycle or disposal of equipment as non-hazardous solid waste pursuant to state and local regulation.

\subsubsection{RCRA Hazardous Waste Determination}

If an exclusion, exemption, or another provision does not apply, PV system equipment meeting the definition of solid waste is regulated as a hazardous waste if it is (1) a listed ${ }^{112}$ hazardous waste or (2) exhibits one or more hazardous characteristics (i.e., ignitability, corrosivity, reactivity, or toxicity). ${ }^{113}$ The person that "generates" PV solid waste (or determines that the PV equipment is solid waste) has the responsibility and legal liability to determine if that equipment is hazardous. ${ }^{114}$ For instance, an asset owner that decommissions a EoL module that has no reuse potential must determine if that module exhibits one or more hazardous characteristics (PV modules are not a listed hazardous waste).

Consideration: Certain PV panel models may contain materials (e.g., cadmium, tellurium, and lead), which may be determined to exceed U.S. federal or state mandated toxicity levels. If the PV module is determined to exceed a federal or state mandated toxicity threshold then that module may be regulated as hazardous waste when accumulated or stored before recycling or when being recycled or disposed of (Nkuissi et al. 2020; Ramos-Ruiz et al. 2017).

To determine whether the EoL module or BOS equipment exhibits hazardous characteristics the person that generates the PV waste can use "acceptable knowledge." Examples of acceptable knowledge include "process knowledge (e.g., information about chemical feedstocks and other inputs to the production process); knowledge of products, by-products, and intermediates produced by the manufacturing process; chemical or physical characterization of wastes; information on the chemical and physical properties of the chemicals used or produced by the process or otherwise contained in the waste; testing that illustrates the properties of the waste; other reliable and relevant information about the properties of the waste or its constituents." 115

In the absence of adequate acceptable knowledge as to whether waste is hazardous, the EoL module or BOS equipment must be tested using an EPA-approved test method, such as the Toxicity Characteristic Leaching Procedure (TCLP). ${ }^{116}$ The TCLP is an-EPA approved test method designed to demonstrate the mobility of organic or inorganic substances through solid and liquid waste (EPA 2019b).

\footnotetext{
112 Because PV modules are not listed as hazardous wastes under RCRA regulations, any discussion of listed hazardous wastes is outside the scope of this report.

11340 C.F.R. $\S \S 261.3(\mathrm{a})(2) ; 261.10,261.20-.24$

11440 C.F.R. $\S 262.11$

11540 C.F.R. $\S 261.11(\mathrm{~d})(1)$

11640 C.F.R. $\S \S 262.11,261.24$
} 
Consideration: Studies have indicated that TCLP analysis results for C-Si PV modules may vary depending on the sampling location on the modules, the sample removal method, the temperature of the glass at the time of sampling, and the test laboratory conducting the TCLP analysis (Leslie 2018; NREL 2019a). Samples from even the same make and model have provided different results (Leslie 2018; NREL 2019a). As a result, there are efforts to consult with the American Society for Testing and Materials to develop and adopt an alternative testing procedure to the TCLP to determine the toxicity of PV modules (NCDEQ 2021).

States that administer their own hazardous waste program may also require additional tests beyond the federal TCLP (EPA 2019d; EPA 2019e). ${ }^{117}$ For example, California requires testing in addition to the TCLP test, including the total digestion and Waste Extraction Test (WET) methods (DTSC 2019a). ${ }^{118}$ Accordingly, in California, a PV module that does not exhibit hazardous characteristics under the TCLP test may still be considered a Non-RCRA Hazardous Waste or California-Only Hazardous Waste if its total digestion and WET results exceed the toxicity threshold (DTSC 2019a; Daniels Training Services, Inc. 2018). Thus, in California, a PV module may not be considered a hazardous waste under the federal RCRA program, but it may be regulated as a hazardous waste under California state law.

\subsection{Regulation of PV System Equipment as Hazardous Waste}

PV system equipment, regulated as hazardous waste, that is accumulated, stored, or treated before recycling or disposal and those being recycled or disposed of must follow stringent handling requirements pursuant to RCRA.

\section{Hazardous Waste Generation}

A person who generates hazardous waste is regulated based on the total amount of hazardous waste they produce per month. Three federal subcategories of hazardous waste generators ${ }^{119}$ have been established:

- Very small quantity generators are entities that generate 100 kilograms (kg) (roughly 220 pounds) or less of hazardous waste per month

- Small quantity generators are entities that generate between $100 \mathrm{~kg}$ (roughly 220 pounds) and $1,000 \mathrm{~kg}$ (roughly 2,200 pounds) of hazardous waste per month

- Large quantity generators are entities that generate $1,000 \mathrm{~kg}$ (roughly 2,200 pounds) or more of hazardous waste (EPA 2019a). ${ }^{120}$

The status of generators recycling hazardous waste PV materials, such as PV modules, can vary based on the weight of the PV module and the generation or accumulation amount. A PV module typically weighs 33-50 pounds depending on the manufacturer and the modules intended use (Ablison Energy 2020; Evergreen Solar 2020; Intermountain Wind \& Solar 2020; CitiGreen, Inc. 2019; Green Coast 2019; Alba Energy 2018; EnergySage 2018; Wholesale Solar 2011). A

\footnotetext{
${ }^{117}$ All 50 states and all U.S. territories have the option to administer a hazardous waste program under RCRA (EPA 2019d, 2019e). However, Alaska, Iowa, Puerto Rico, and the U.S. Virgin Islands do not have an EPAapproved hazardous waste program (EPA 2019d, 2019e).

${ }^{118}$ Cal. Code Regs. tit. 22, § 66261.24(a)(2)

${ }^{119}$ A "generator" is any person, by site, whose act or process produces hazardous waste identified or listed in 40 C.F.R. $\S 261$ or whose act first causes a hazardous waste to become subject to regulation (40 C.F.R. $\S 260.10$ ).

12040 C.F.R. $\S 260.10$
} 
generator's status may also change from month to month if their monthly accumulation or generation amount changes. ${ }^{121,122}$

Example: Given that a PV module typically weighs approximately 33-50 pounds, a person could be regulated as a small quantity generator with as little as just 5-7 modules that qualify as hazardous waste.

\subsection{Regulation of PV System Equipment as Universal Waste}

California recently passed a regulation allowing PV modules to be regulated as universal waste. Universal waste is a subset of hazardous waste that generally has less-stringent waste management requirements than hazardous waste regulations, but typically treat disposal and recycling in a similar manner (i.e., same requirements and same liabilities for noncompliance). ${ }^{123,124}$ The EPA passed the universal waste regulations to streamline hazardous waste management regulations for certain common categories of hazardous waste (EPA 2019a). ${ }^{125,126}$ Generators and others handling these waste streams are not required to manage their qualifying hazardous waste as universal waste; universal waste regulations are an optional alternative to the hazardous waste regulations for qualifying hazardous wastes. ${ }^{127}$

Consideration: One potential advantage of managing a solid waste as universal waste is to avoid often costly and variable TCLP testing to determine whether a solid waste exhibits one or more hazardous characteristics and must be regulated as a hazardous waste (CSSA 2020).

Because the universal waste rules are less stringent than the hazardous waste rules, any state that administers its own RCRA hazardous waste program can choose to adopt any or none of the federal universal waste categories (EPA 2019d). States that administer hazardous waste programs can also create additional universal waste categories within their state programs if: 1) the waste is generated by a wide variety of entities, 2) is not exclusive to a specific industry, and 3 ) is hazardous. States may also delegate regulatory authority to local governments. Accordingly, state and local universal waste program requirements regarding the handling, storage, treatment, transport, recycling, and disposal of PV equipment also may vary by local jurisdiction (EPA 2019d). As of February 2021, only one state - California - has enacted a regulation that would allow PV modules to be managed as universal waste rather than a fully regulated hazardous waste, however New York and North Carolina are also considering similar regulation (Section 5.1.4).

\footnotetext{
12140 C.F.R. $\S 262.13$

122 Daniel Stoehr, Daniels Training Services, Inc., teleconference, August 30, 2019

${ }^{123}$ Universal Waste Rule, 60 Fed. Reg. 25,492, 25,492 (May 11, 1995) (to be codified at 40 C.F.R. Parts 9, 260, $261,262,264,265,266,268,270$, and 273).

12440 C.F.R. $\S \S 260-265,273$

12540 C.F.R. $\$ \S 260-265,273$

${ }^{126}$ Universal Waste Rule, 60 Fed. Reg. 25,492, 25,492 (May 11, 1995) (to be codified at 40 C.F.R. Parts 9, 260, $261,262,264,265,266,268,270$, and 273)

12740 C.F.R. $\S 273.1(b)$
} 
Considerations: Similar to universal waste regulation, the EPA has also created alternative regulatory controls for certain materials when they are recycled to encourage the collection and recycling of certain categories of hazardous waste. For example, federal EPA regulations allow leadacid batteries to be regulated as universal waste or pursuant to alternative regulatory controls that have less-stringent requirements for the handling, regeneration, collection, and storage of spent leadacid batteries before reclamation. ${ }^{128}$ In comparison to universal waste regulations these alternative regulations do not apply to lead-acid batteries being disposed of. ${ }^{129} \mathrm{~A}$ similar federal designation for PV modules could reduce liability concerns and make the economics of recycling PV modules more competitive with disposal.

Although Washington State has not listed PV modules as a universal waste, the Washington State Department of Ecology has created an alternative "interim enforcement policy" that allows PV modules when recycled to be regulated under alternative standards that are less stringent than the state's hazardous waste regulations (Wash. Admin. Code § 173-303-040; WSDE 2020; WSDE 2007; WSDE n.d.) (Section 5.1.1). Notably, the interim enforcement policy only applies to modules destined for recycling and specifies that modules destined for disposal are still subject to the dangerous waste regulations (state-equivalent to hazardous waste) (WSDE 2007). Reducing the regulatory burden for PV modules being recycled in comparison to those being disposed of may provide an incentive to recycle especially when the economics of disposal are currently more favorable.

\section{Universal Waste Handling}

A person who handles universal waste may be regulated based on the total amount of universal waste accumulated at any time. Two subcategories of universal waste handlers have been established by federal regulation:

- Small quantity handlers of universal waste are entities that accumulate less than 5,000 $\mathrm{kg}$ (roughly 11,000 pounds) of universal waste at any time

- Large quantity handlers of universal waste are entities that accumulate 5,000 or more $\mathrm{kg}$ of universal waste at any time. ${ }^{130}$

Similar to the discussion above (Section 4.2), the status of handlers recycling PV equipment that are regulated as universal waste can vary based on the weight of the PV equipment (e.g., PV modules) and the generation or accumulation amount. A PV module typically weighs 33-50 pounds depending on the manufacturer and the modules intended use (Ablison Energy 2020; Evergreen Solar 2020; Intermountain Wind \& Solar 2020; CitiGreen, Inc. 2019; Green Coast 2019; Alba Energy 2018; Energy Sage 2018; Wholesale Solar 2011). A universal waste handler's status could change if they resume managing their universal waste as hazardous waste. 131,132

\subsection{Comparison of Hazardous Waste and Universal Waste Handling, Storage, and Transport Requirements}

In this section, we compare federal RCRA requirements for materials designated as hazardous waste and universal waste. It is important to note that states that have authorization to administer

\footnotetext{
12840 C.F.R. $\S 266.80$

12940 C.F.R. $\$ 266.80$

13040 C.F.R. $\S 273.9$

13140 C.F.R. § 262.13

${ }^{132}$ Daniel Stoehr, Daniels Training Services, Inc., teleconference, August 30, 2019
} 
their own hazardous waste programs may choose to include requirements beyond the federal requirements discussed in this section (EPA 2019d, EPA 2019e).

\subsubsection{Generator and Handler Requirements}

Generally, handling requirements vary based on the classification of waste (i.e., hazardous or universal) and the quantity of waste produced or accumulated. Table 6 compares federal requirements for hazardous waste generators and universal waste handlers.

Table 6. Federal Hazardous Waste Generator and Universal Waste Handler Requirements ${ }^{a}$

\begin{tabular}{|c|c|c|c|c|c|}
\hline \multirow[b]{2}{*}{ Requirement } & \multicolumn{3}{|c|}{ Hazardous Waste } & \multicolumn{2}{|c|}{ Universal Waste } \\
\hline & $\begin{array}{l}\text { Very Small } \\
\text { Quantity } \\
\text { Generators }\end{array}$ & $\begin{array}{l}\text { Small } \\
\text { Quantity } \\
\text { Generators }\end{array}$ & $\begin{array}{l}\text { Large } \\
\text { Quantity } \\
\text { Generators }\end{array}$ & $\begin{array}{l}\text { Small Quantity } \\
\text { Handlers of } \\
\text { Universal } \\
\text { Waste }\end{array}$ & $\begin{array}{l}\text { Large } \\
\text { Quantity } \\
\text { Handlers of } \\
\text { Universal } \\
\text { Waste }\end{array}$ \\
\hline $\begin{array}{l}\text { EPA } \\
\text { identification } \\
\text { number }\end{array}$ & Not required & Required & Required & Not required & Required \\
\hline $\begin{array}{l}\text { On-site } \\
\text { accumulation } \\
\text { limit }\end{array}$ & $\begin{array}{l}\text { Less than } \\
1,000 \text { kg per } \\
\text { month } \\
\text { (roughly } \\
2,200 \\
\text { pounds) }\end{array}$ & $\begin{array}{l}\text { Less than } \\
6,000 \mathrm{~kg} \text { per } \\
\text { month }\end{array}$ & No limit & $\begin{array}{l}\text { Less than } \\
5,000 \mathrm{~kg} \text { (total at } \\
\text { one time) }\end{array}$ & No limit \\
\hline $\begin{array}{l}\text { Storage time } \\
\text { limit (without a } \\
\text { storage permit) }\end{array}$ & No limit & $\begin{array}{l}\text { Less than } 180 \\
\text { days (or less } \\
\text { than } 270 \text { days } \\
\text { if transporting } \\
\text { more than } 200 \\
\text { miles) }\end{array}$ & $\begin{array}{l}\text { Less than } \\
90 \text { days }\end{array}$ & 1 yearb $^{b}$ & 1 yearc $^{c}$ \\
\hline Manifest $^{d}$ & Not required & Required & Required & Not required & $\begin{array}{l}\text { Full manifest } \\
\text { not required, } \\
\text { but must keep } \\
\text { basic shipping } \\
\text { records }\end{array}$ \\
\hline $\begin{array}{l}\text { Personnel } \\
\text { training }\end{array}$ & Not required & $\begin{array}{l}\text { Basic training } \\
\text { required }\end{array}$ & Required & Basic training & $\begin{array}{l}\text { Basic training } \\
\text { that is tailored } \\
\text { to employees' } \\
\text { responsibilities }\end{array}$ \\
\hline
\end{tabular}

a The table is from EPA (2019a). It reflects only the federal minimum requirements; it does not reflect state or local requirements.

b Small quantity handlers of universal waste may accumulate universal waste for longer than one year if they can prove the extended accumulation period is solely for the purpose of accumulating enough of the universal waste to facilitate proper recovery, treatment, or disposal (40 C.F.R. § 273.15(b)).

${ }^{c}$ Large quantity handlers of universal waste may accumulate universal waste for longer than one year if they can prove the extended accumulation period is solely for the purpose of accumulating enough of the universal waste to facilitate proper recovery, treatment, or disposal (40 C.F.R. $\S 273.35(b))$.

d A manifest is "the shipping document EPA Form 8700-22 (including, if necessary, EPA Form 8700-22A), or the electronic manifest, originated and signed in accordance with the applicable requirements" (40 
C.F.R. $\S 260.10)$. A manifest form can only be printed and distributed by a printer registered with the EPA (EPA 2020b). The manifest includes information about the type and quantity of the waste being transported, instructions for handling the waste, and spaces for signatures of every party involved in the entire process (EPA 2020b).

\subsubsection{Treatment, Storage, and Disposal Facility and Destination Facility Requirements}

Any person that stores PV equipment (e.g., modules), regulated as hazardous or universal waste, prior to recycling or disposal may be subject to additional RCRA requirements. Hazardous waste generators who store PV equipment regulated as hazardous waste before recycling, or secondary hazardous materials before reclamation longer than the generator regulations (Section 4.4.1) allow must comply with hazardous waste treatment, storage, and disposal facility (TSDF) requirements. ${ }^{133,134}$ Similarly, universal waste handlers that store PV equipment classified as universal waste before recycling (which includes reclamation) longer than the handler regulations (Section 4.4.1) allow must comply with universal waste destination facility requirements or be subject to a penalty for non-compliance EPA 2019a). ${ }^{135,136,137}$

Third-party recyclers that accept PV equipment classified as hazardous or universal waste must also comply with TSDF or destination facility regulatory requirements if they store hazardous or universal waste for any amount of time before recycling. ${ }^{138}$ Recyclers that do not store hazardous or universal waste before recycling are not subject to TSDF or destination facility requirements, but must still comply with notice, manifest, reporting, and other federal requirements outlined in 40 C.F.R. $\S \S 261.6(c)-(d)$.

The main difference between regulation as a hazardous waste TSDF and a universal waste destination facility is that TSDFs have a manifest requirement and universal waste destination facilities do not, but universal waste destination facilities must keep waste shipment receipt records on site. ${ }^{139}$ Key federal requirements for hazardous waste TSDFs and universal waste destination facilities include:

- Notification about location and description of waste type and management activities

- EPA identification number

- RCRA permit

- Chemical and physical analysis of incoming waste

- Security measures and facility inspections

- Personnel training

- Facility siting location standards compliance

- Communication/alarm system and safety equipment

- Coordination with local authorities on precautionary arrangements

- Contingency plan management

\footnotetext{
13340 C.F.R. $\S \S 264.1,260.10,261.6(c)(1)-(c)(2)$

13440 C.F.R. $\$ 260.10$

13540 C.F.R. $\S 273.60$ (b)

13640 C.F.R. $\S 261.6(\mathrm{c})(2)$

13740 C.F.R. $\S 273.60$

13840 C.F.R. $\S \S 264.6(\mathrm{c})(2)$

13940 C.F.R. $\S 273.62$
} 
- On-site or on-call emergency coordinator

- Manifests (required for TSDFs only, destination facilities must keep shipment records on site)

- Facility operating records

- Biennial reports regarding the nature, quantities, and disposition of waste generated at the facility, which must be submitted to the EPA or state

- Groundwater standard violation detection, monitoring, and response program

- Closure and post-closure plans, cost estimations, and assurances

- Air emission standards for process vents and equipment leaks ${ }^{140}$

\subsection{Transport and Export Requirements}

Transporters of PV equipment regulated as hazardous or universal waste may be subject to specific packaging, documentation, and other transit-related related requirements. Also, export regulations may apply. In this section, we discuss RCRA hazardous and universal transporter regulations, as well as U.S. Department of Transportation (DOT) hazardous materials regulations $(\mathrm{HMR})^{141}$ for highway and rail transport, air transport, and sea transport. In addition, we discuss RCRA hazardous and universal waste and international transboundary export requirements.

RCRA defines hazardous and universal waste transporters as "persons engaged in the offsite transportation of hazardous or universal waste by air, rail, highway, or water." 142 Table 7 compares federal requirements for hazardous and universal waste transporters.

Table 7. Federal Hazardous Waste Transporter and Universal Waste Transporter Requirements ${ }^{\mathrm{a}}$

\begin{tabular}{|l|l|l|}
\hline Requirement & Hazardous Waste Transporter & Universal Waste Transporter \\
\hline EPA identification number & Yes & No \\
\hline Manifest & Yes & No \\
\hline Release response ${ }^{\text {b }}$ & Yes & $\begin{array}{l}\text { Yes (but with less-stringent } \\
\text { requirements) }\end{array}$ \\
\hline $\begin{array}{l}\text { Universal waste handler } \\
\text { regulations (Section 4.4.1) }\end{array}$ & $\begin{array}{l}\text { No (but subject to 40 C.F.R Part } \\
263)\end{array}$ & $\begin{array}{l}\text { Yes, if universal waste is stored at } \\
\text { transfer facilityc for more than 10 } \\
\text { days }\end{array}$ \\
\hline $\begin{array}{l}\text { Hazardous waste TSDF } \\
\text { regulations (Section 4.4.2) }\end{array}$ & $\begin{array}{l}\text { Yes, if hazardous waste is stored } \\
\text { at a transfer facility } \text { for more than } \\
10 \text { days }\end{array}$ & No \\
\hline
\end{tabular}

a The table reflects only the federal minimum; it does not reflect state or local requirements (40 C.F.R. $\S \S$ 260, 263, 273; EPA 2019a)

${ }^{\mathrm{b}}$ Refers to the action(s) a transporter must take in the event of a hazardous or universal waste discharge or release during transportation (40 C.F.R. §§ 263.30-31, 273.54).

c Universal waste transfer facility means any transportation-related facility including loading docks, parking areas, storage areas and other similar areas where shipments of universal waste are held during the normal course of transportation for ten days or less (40 C.F.R. $\S 273.9$ ).

\footnotetext{
14040 C.F.R. $\S \S 273.60-.62$

14149 C.F.R. $\S \S 171-180$

14240 C.F.R. $\S \S 260.10,273.9$
} 
${ }^{\mathrm{d}}$ Hazard waste transfer facility means any transportation-related facility, including loading docks, parking areas, storage areas and other similar areas where shipments of hazardous waste or hazardous secondary materials are held during the normal course of transportation (40 C.F.R. $§ 260.10$ ).

\subsubsection{Transportation by Highway, Rail, Air, or Sea}

Any person engaged in the offsite transportation of PV equipment regulated as "hazardous waste ${ }^{143}$ to, through, or from the United States by highway, rail, air or sea" must also comply with DOT hazardous materials regulations. ${ }^{144,145,146}$ Although not specifically addressed within DOT regulations, PV equipment, such as modules that require a RCRA hazardous waste manifest may be regulated as a Class 9 hazardous material. ${ }^{147,148} \mathrm{~A}$ hazardous material is defined in part as "a substance or material that...is capable of posing an unreasonable risk to health, safety, and property when transported in commerce." 149

DOT hazardous materials requirements may include, but are not limited to:

- Packaging requirements

- Hazard communication requirements (e.g., package markings, labels, placards for vehicles)

- Hazardous materials shipping papers, which accompany the shipment (e.g., Hazardous Waste Manifest, Emergency Response Information, Emergency Response Contact Number)

- Hazardous materials training for all employees who prepare shipments, offer them into transportation, and transport ${ }^{150,151,152}$

- Enhanced packaging, additional markings or labels, quantity limitations, and cargo handling, stowage, and location considerations (e.g., segregation from other hazardous material in cargo areas on a ship or placement of hazardous materials in accessible cargo holds in airplanes). ${ }^{153}$

\footnotetext{
${ }^{143}$ For the purposes of DOT regulations, "hazardous waste" means any material that is subject to the Hazardous Waste Manifest Requirements of the U.S. EPA (49 C.F.R. § 171.8).

14449 C.F.R. $\S \S 171-180$

145 The DOT authorizes compliance with the International Civil Aviation Organization's Technical Instructions, the International Air Transport Association's Dangerous Goods Regulation, and the International Maritime Dangerous Goods Code to meet DOT standards for air and sea transport, respectively (49 C.F.R. § 171.22(a); 49 C.F.R. § 171.7(v); PHMSA 2017a; PHMSA 2017b). These standards are discussed below in Section 4.5.

14649 U.S.C. $\$ \S 5101-5128$

14749 C.F.R. $\S \S 171-180$

${ }^{148}$ Pursuant to DOT regulations, it is a shipper's responsibility to properly classify and describe hazardous materials (49 C.F.R. $\S \S 173.2,173.22$ ). PV modules that do not meet any of the other hazardous classes (e.g., flammable, corrosive, toxic), but require a Hazardous Waste Manifest would be regulated as a Class 9 hazardous material (49 C.F.R. $\S \S 172.101,173.140,173.205)$.

14949 C.F.R. $\$ 171.8$

15040 C.F.R. $\$ 273.52$

15149 C.F.R. § 172.446, 172.560, 172.606, 172.704, 172.205

${ }^{152}$ Hazardous waste transporters might want to also be aware of any additional provisions in the Hazardous Materials Table that could apply (49 C.F.R. § 172.101).

15349 C.F.R. $\S \S 173.21-173.41$
} 
Consideration: Although universal wastes are considered hazardous wastes under RCRA, universal wastes are not automatically considered hazardous wastes under the DOT hazardous materials regulations as they do not require hazardous waste manifests when transported (40 C.F.R. § 273.52). Accordingly, PV system equipment, such as modules regulated as universal waste - that do not meet any other hazardous materials regulations classification (e.g., flammable, corrosive, toxic) - are not subject to DOT hazardous materials regulations.

In addition to DOT hazardous materials regulations, any person transporting PV equipment for reuse, recycling, or disposal by air or vessel domestically and/or internationally (e.g., transboundary transportation) should be aware that the DOT authorizes compliance with the International Civil Aviation Organization (ICAO) Technical Instructions and the International Maritime Dangerous Goods (IMDG) code (PHMSA 2017a; PHMSA 2017b). ${ }^{154,155}$ The ICAO Technical Instructions and IMDG Code regulate packaging, labeling, and training standards related to the shipment of hazardous materials via airplane or vessel (PHMSA 2017a). ${ }^{156}$ Accordingly, PV equipment regulated as hazardous waste, which is transported by air or vessel may be regulated as dangerous goods (e.g. hazardous material) under DOT regulations, ICAO Technical Instructions, and/or the IMDG Code.

Consideration: Currently, neither the ICAO Technical Instructions nor the IMDG Code specifically address PV modules. Accordingly, there is uncertainty regarding the applicability of existing air and vessel transportation standards to PV modules destined for reuse, recycling, or disposal.

\subsubsection{Export}

Exporting PV system equipment from the United States for "resource recovery, recycling, reclamation, direct reuse, or alternatives uses" may trigger compliance with RCRA and international transboundary requirements, such as:

- Organization for Economic Cooperation and Development (OECD) Council Decision on the Control of Transboundary Movements of Wastes Destined for Recovery Operations (Council Decision)

- The Basel Convention on the Transboundary Movements of Hazardous Wastes and their Disposal (Basel Convention) (EPA 2019f; EPA 2019c). ${ }^{157,158}$

RCRA regulations incorporate by reference the OECD requirements and provide specific provisions for exports to Canada. ${ }^{159}$ The United States is not a party to the Basel Convention; however, the OECD requirements largely reflect the Basel Convention requirements. ${ }^{160}$ Hazardous wastes are considered "amber list" wastes pursuant to OECD and Basel Convention requirements, and they require compliance with international transport agreements and all

\footnotetext{
${ }^{154}$ Daniel Stoehr, Daniels Training Services, Inc., teleconference, August 30, 2019

15549 C.F.R. $\S \S 171.7(\mathrm{v}) ; 171.22(\mathrm{a})$

${ }^{156}$ Daniel Stoehr, Daniels Training Services, Inc., teleconference, August 30, 2019

15740 C.F.R. $\S \S 262.80,262.81$

${ }^{158}$ Daniel Stoehr, Daniels Training Services, Inc., teleconference, August 30, 2019

15940 C.F.R. $\S \S 262.80-262.83 ; 40$ C.F.R. $\S 260.11$

${ }^{160}$ Jordan Rivera, U.S. Department of Transportation, Headquarters, email, September 30, 2020; Neal Suchak, U.S.

Department of Transportation, Headquarters, email, September 30, 2020.
} 
applicable laws and regulations, both international and national. ${ }^{161}$ Transboundary export requirements include:

- EPA acknowledgement of consent documenting the specific terms of the destination country's import requirements and consent

- Compliance with the acknowledgement of consent contract requirements, including notification and tracking specifications, movement documentation, and manifest instructions

- Detailed annual reporting to EPA

- Detailed recordkeeping. ${ }^{162}$

\subsection{Penalties for Non-Compliance}

Solar industry stakeholders might want to consider the potential for civil and criminal liabilities associated with violations of hazardous waste and hazardous materials regulations. Violations may occur during a hazardous waste or hazardous materials determination, the generation, handling, transportation, treatment, storage, recycling or disposal of PV system equipment (e.g., modules) classified as hazardous or universal waste, or during the transportation of hazardous materials. This section discusses some, but not all, of the liabilities associated with RCRA and DOT domestic law violations.

\subsubsection{RCRA Hazardous and Universal Waste Regulations}

Non-compliance with any RCRA provision could result in civil and criminal penalties. ${ }^{163}$ The EPA has authority to:

- Issue an order assessing a civil penalty of up to $\$ 101,439$ per violation per day of noncompliance

- Issue an order requiring immediate compliance within a specified period

- Issue both a civil penalty and a compliance order

- Commence a civil action in the appropriate U.S. District Court for penalties and for appropriate injunctive relief, including temporary or permanent injunctions. ${ }^{164}$

The EPA can also assess a penalty of up to $\$ 61,098$ per violation per day for non-compliance with a compliance order, and it can suspend or revoke the violator's permits. ${ }^{165}$

Criminal non-compliance with a RCRA provision could also result in a penalty of up to $\$ 50,000$ per violation per day, up to two years of imprisonment, or both for:

- Knowingly omitting material information or making any false material statement or representation in any application, label, manifest, record, report, permit, or other document filed, maintained, or used for purposes of compliance with federal or state regulations

\footnotetext{
16140 C.F.R. $\S 262.82(\mathrm{~b}))$

16240 C.F.R. $\$ 262.83$

16342 U.S.C. $\$ 6928$

16440 C.F.R. $\$ 19.4$

16540 C.F.R. $\S 19.4$
} 
- Knowingly generating, storing, treating, transporting, disposing of, exporting, or otherwise handling any characteristic hazardous waste and knowingly destroying, altering, concealing, or failing to file any record, application, manifest, report, or other document required to be maintained or filed for purposes of compliance with regulations

- Knowingly transporting without a manifest, or causing to be transported without a manifest, any "characteristic hazardous waste" required by federal or state hazardous waste regulations to be accompanied by a manifest. ${ }^{166}$

If anyone knowingly commits one of the above violations and also knows that the violation puts another person in imminent danger of death or serious bodily injury, they may be subject to a fine of up to $\$ 250,000$ (up to $\$ 1$ million if the violator is an organization), up to 15 years of imprisonment, or both. ${ }^{167}$

Considerations: State penalties for violating hazardous waste regulations may be more stringent than the penalties outlined in federal regulations (EPA 2019d, 2019e). For example, if a person in California intentionally or negligently violates a provision of California's hazardous waste laws or regulations or of a permit issued pursuant to those laws and regulations, they could be liable for up to $\$ 70,000$ per violation of a separate provision for each day that the violation continues. ${ }^{168}$

\subsubsection{DOT Hazardous Materials Regulations}

Non-compliance with DOT hazardous materials regulations, orders, special permits, or approvals may result in civil or criminal penalties. ${ }^{169}$ The Secretary of Transportation may bring civil actions to enforce DOT hazardous material regulations, orders, special permits, or approvals, or, if the Secretary has reason to believe an imminent hazard exists, to suspend or restrict transportation of the hazardous material or to eliminate or mitigate the hazard. ${ }^{170}$ Civil penalties could include:

- Up to $\$ 83,439$ for each violation knowingly committed

- Up to $\$ 194,691$ for each violation knowingly committed that results in death, serious illness, or sever injury to any person or in substantial destruction of property

- At least $\$ 502$ per violation related to training. ${ }^{171}$

A separate violation occurs each day the violation continues. ${ }^{172}$

A person who knowingly, willfully, or recklessly violates any DOT hazardous material regulations, orders, special permits, or approvals could be subject to criminal penalties including fines, up to five years of imprisonment (up to 10 years if the violation involves the release of a hazardous material that results in death or bodily injury to a person), or both. ${ }^{173}$

\footnotetext{
16642 U.S.C. $\S 6928(\mathrm{~d})$

16742 U.S.C. $\$ 6928(\mathrm{e})$

${ }^{168}$ Cal. Health and Safety Code $\S 25189$

16949 U.S.C. $\S \S 5122-5124$

17049 U.S.C. $\$ 5122(\mathrm{a})-(\mathrm{b})$

17149 C.F.R. $\S 107.329$

17249 U.S.C. $\S 5123(\mathrm{a})$

17349 U.S.C. $§ 5124(\mathrm{a})$
} 


\section{State Policies}

Solar industry stakeholders may want to consider state policies ${ }^{174}$ that explicitly address PV system decommissioning and/or repair/reuse/recycling of PV system equipment. As of February 2021, no U.S. federal policies address PV system decommissioning or repair/reuse/recycling of PV system equipment. Washington, New Jersey, North Carolina, and California are the only U.S. states with laws and/or regulations that directly address PV system decommissioning, PV equipment reuse, and/or EoL management options for PV system equipment. However, California, Hawaii, and Rhode Island have proposed bills that, if enacted, would directly address repair/reuse/recycling of PV system equipment. There are also state-led working groups in California, Illinois, and Minnesota to study reuse and EoL options for PV equipment. Figure 2 maps state policies in the United States that address PV system decommissioning, PV equipment reuse, and/or EoL management options.

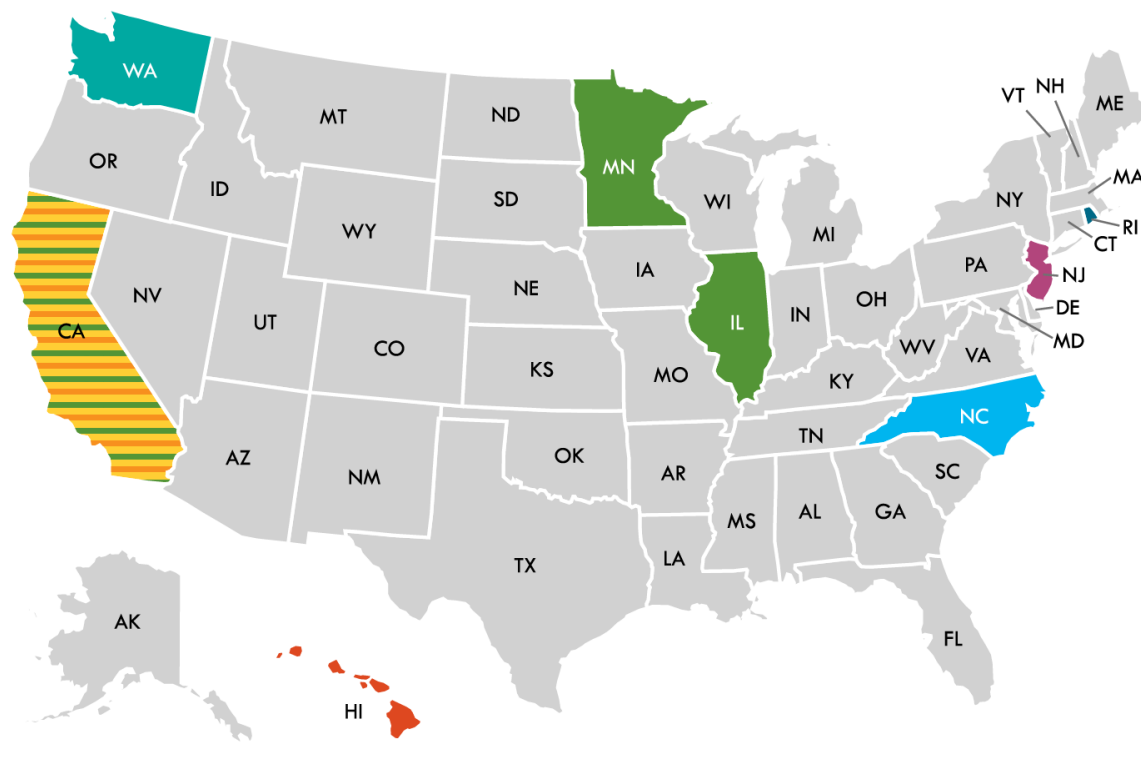

\section{Enacted Policies}

PV Module Manufacturer Takeback

Commission to Study PV System Decommissioning, PV Module Reuse, and PV Module EoL Management Options

Commission to Study PV Module EoL Management Options

PV Module Universal Waste Classification

Proposed (Pending) Legislation

Proposed Legislation - Commission to Study PV Module Reuse and PV Module EoL Management Options

Proposed Legislation - Commission to Study PV Module and BOS Equipment EoL Management Options

Proposed Legislation - PV Module Manufacturer Takeback

State-Led Initiatives

Working Group to Study PV Module and BOS Equipment Reuse and EoL Management Options

Figure 2. State PV system decommissioning, and PV equipment reuse and EoL management policies (enacted, pending, and state-led initiatives)

\footnotetext{
${ }^{174}$ We use "policy" in this report broadly to include not only state statutory and regulatory requirements but also government initiatives and goals and independently formed working groups.
} 


\subsection{Enacted Legislation and Regulation}

This section summarizes existing U.S. state laws and regulations that explicitly address PV system decommissioning and/or the repair/reuse/recycling of PV system equipment.

\subsubsection{Washington}

In 2017, the Washington State Legislature passed Senate Bill 5939 to promote a sustainable local renewable energy industry by modifying tax incentives. ${ }^{175}$ A portion of the bill created the Photovoltaic Module Stewardship and Takeback Program (Program), which requires PV module manufacturers ${ }^{176}$ to finance and implement a takeback and recycling or reuse stewardship plan for PV modules sold after July 1, 2017, at no cost to owners. ${ }^{177}$ Specifically, beginning July 1, 2023, no manufacturer, distributor, retailer, or installer may sell or offer for sale PV modules within or into Washington unless the manufacturer of the PV module has submitted a stewardship plan to the Department of Ecology and obtained approval. ${ }^{178}$ PV modules covered by the state's Program include:

- PV modules used for residential, commercial, agricultural, or utility purposes that are installed on, connected to, or integral with buildings, or are part of a system connected to the grid or utility service

- Freestanding off-grid power generation systems, such as water pumping stations, electric vehicle charging stations, solar fencing, solar-powered signs, and solar-powered streetlights (WSDE 2020). ${ }^{179}$

Manufacturers must submit a stewardship plan to the Department of Ecology and then implement the plan by July 2022. Manufacturers can either create and implement a stewardship plan individually or join a registered stewardship organization and allow that organization to create and implement the plan on the manufacturer's behalf. ${ }^{180}$ The stewardship plan must outline how the manufacturer will:

- Finance the takeback program

- Accept all their PV modules sold within or into the state after July 1, 2017

- Minimize the release of hazardous substances and maximize the recovery of other components

\footnotetext{
175 S.B. 5939, 65th Leg., 3rd Spec. Sess. (Wash. 2018)

176 “'Manufacturer' means any person in business or no longer in business but having a successor in interest who, irrespective of the selling technique used, including by means of distance or remote sale: (i) manufactures or has manufactured a PV module under its own brand names for sale in or into this state; (ii) assembles or has assembled a PV module that uses parts manufactured by others for sale in or into this state under the assembler's brand names; (iii) resells or has resold in or into this state under its own brand names a PV module produced by other suppliers, including retail establishments that sell PV modules under their own brand names; (iv) manufactures or has manufactured a cobranded PV module product for sale in or into this state that carries the name of both the manufacturer and a retailer; (v) imports or has imported a PV module in the U.S. that is sold in or into the state; (vi) sells at retail a PV module acquired from an importer that is the manufacturer; or (vii) elects to assume the responsibility and register in lieu of a manufacturer" (Wash. Rev. Code $\S 70$ A.510.010(2)(c)).

177 Wash. Rev. Code $\S 70$ A.510.010(5)

178 Wash. Rev. Code $\S$ 70A.510.010(8)

${ }^{179}$ Wash. Rev. Code $\S 70$ A.510.010(2)(f)

${ }^{180}$ Wash. Rev. Code $\S 70 A .510 .010(3)$
} 
- Provide convenient takeback opportunities in regions of Washington where its modules are used

- Disseminate applicable information about its program to relevant stakeholders

- Implement performance goals to reuse and/or recycle at least $85 \%$ of the PV modules the manufacturer collects. ${ }^{181}$

After initial approval of the stewardship plans, the manufacturer must submit and publish annual reports about the previous year's implementation of the manufacturer's plan, starting in 2024. The annual reports must include achievement assessments of the plan's performance goals and may include recommendations to the Department of Ecology or the Washington State Legislature on potential modifications to improve the effectiveness of the Program. ${ }^{182}$

The Department of Ecology may collect a flat fee from every participating manufacturer to cover the costs of administering the Program and an annual fee from each manufacturer based on the manufacturer's pro rata share of the preceding year's PV module sales in Washington. ${ }^{183}$ The Department of Ecology may, after issuing a warning of non-compliance, impose a penalty of up to $\$ 10,000$ per sale of a PV module in Washington. ${ }^{184}$ The Department of Ecology must deposit all fees and penalties into a PV module recycling account that can only be used to fund the Program's administration costs. ${ }^{185}$

In July 2019, the Department of Ecology released guidance for manufacturers that explains their responsibilities and requirements under the Program and how the Department of Ecology will review and approve stewardship plans (WSDE 2020). The guidance also states that stewardship plans must follow the Department of Ecology's Interim Enforcement Policy for Conditional Exclusion for Electronic Wastes, which is intended to encourage recycling of electronic waste. It states that covered electronic wastes "generated, transported, collected, accumulated and recycled do not have to be counted as dangerous waste (i.e., hazardous waste) or manifested when transported off-site" (WSDE 2007).

Consideration: Potential advantages associated with Washington's Program is that it requires environmentally sustainable PV management by mandating reuse and recycling. In addition, the Program incentivizes recycling over disposal by reducing the regulatory burden and not requiring PV modules being recycled to be regulated as dangerous waste (which does not apply to modules being disposed of) (Christine Haun, Washington Department of Ecology, telephone conference, May 10, 2019; PSI 2018; 2019 Wash. Sess. Laws 1608; Governor Jay Inslee 2019). However, anecdotal evidence suggests that the Program may disproportionately impact PV manufacturers, distributors, retailers, and installers, which could ultimately discourage the sale of PV modules in Washington (PSI 2018).

\footnotetext{
${ }^{181}$ Wash. Rev. Code $\S 70$ A.510.010(5)

182 Wash. Rev. Code $\S$ 70A.510.010(6), (7)

${ }^{183}$ Wash. Rev. Code $\S$ 70A.510.010(9)

${ }^{184}$ Wash. Rev. Code $§$ 70A.510.010(8)

${ }^{185}$ Wash. Rev. Code $§$ 70A.510.010(10)
} 


\subsubsection{New Jersey}

On August 9, 2019, the New Jersey Legislature passed Senate Bill 601, which created the New Jersey Solar Panel Recycling Commission (Governor Phil Murphy 2019). ${ }^{186}$ The Commission is tasked with investigating EoL management options for PV and other solar energy generation structures. The Commission is also tasked with developing recommendations for legislative, administrative, or private-sector action. ${ }^{187}$ The Commission consists of nine governorappointed voting members:

- The Commissioner of the New Jersey Department of Environmental Protection (or their designee)

- The Commissioner of the New Jersey Department of Community Affairs (or their designee)

- Two governor-appointed members of New Jersey's business community with experience or expertise in Class D recycling ${ }^{188}$ and the disposal of consumer electronics

- One governor-appointed representative of a that promotes recycling in New Jersey

- Two governor-appointed members who work in the solar industry

- Two governor-appointed academic community members with expertise in recycling. ${ }^{189}$

The Commission can use the services of any state, county, or municipal employee to investigate options for EoL PV recycling and management. ${ }^{190}$ The Commission must also submit the findings of its investigation and recommendations as a final report to the governor and post it on the Department of Environmental Protection's website no later than August 2021. ${ }^{191}$ The bill also authorizes the Department of Environmental Protection to adopt rules and regulations regarding EoL PV recycling or management options based on the Commission's final report. ${ }^{192}$

Consideration: A potential advantage of New Jersey's policy is that it requires a study to consider different PV EoL management options - such as recycling - as well as associated barriers to inform the development of new regulations. However, because the bill establishing the Commission does not mandate the adoption of rules and regulations, it is unclear whether the Commission's final report will have any bearing on the development of EoL PV management options in New Jersey. ${ }^{193}$

\footnotetext{
1862019 N.J. Sess. Law Serv. Ch. 215 (West)

1872019 N.J. Sess. Law Serv. Ch. 215 (West)

${ }^{188}$ Class D recyclables include used oil, batteries, thermostats, lamps, oil-based finishes, mercury-containing devices, consumer electronics, latex paints, and antifreeze (N.J. Admin. Code § 7:26A-1.3 [2017]).

1892019 N.J. Sess. Law Serv. Ch. 215 (West)

1902019 N.J. Sess. Law Serv. Ch. 215 (West)

1912019 N.J. Sess. Law Serv. Ch. 215 (West)

1922019 N.J. Sess. Law Serv. Ch. 215 (West)

${ }^{193}$ We were unable to find any evidence that the New Jersey Solar Panel Recycling Commission has been formed or of any action regarding 2019 N.J. Sess. Law Serv. Ch. 215 (West).
} 


\subsubsection{North Carolina}

On July 19, 2019, the North Carolina General Assembly passed House Bill 329, to study and consider the adoption of regulations to govern the decommissioning and the reuse and $\mathrm{EoL}$ management of PV modules used in utility-scale projects. ${ }^{194,195}$ The law tasked the Department of Environmental Quality, which includes the Environmental Management Commission, with considering:

- Whether PV modules are properly characterized as solid waste under state and federal law

- Whether PV modules exhibit characteristics of hazardous solid waste

- The preferred PV modules and other equipment management methods and economic and environmental costs and benefits associated with each method

- The expected economically productive lifecycle of different types of PV modules

- The volume of PV modules deployed in the state, the projected PV deployment in the future, and the impact that volume would have on state landfills if landfill disposal were permitted

- A survey of federal, state, and international regulatory requirements related to EoL PV modules and other equipment management, decommissioning, and financial assurances

- The need for financial assurance requirements for PV system decommissioning

- The infrastructure needed to collect and transport EoL PV modules and other equipment for reuse, refurbishment, recycling, or disposal

- Whether stewardship programs for recycling EoL PV modules should be established for applications other than utility-scale solar projects and, if so, fees that should be established for manufacturers to sell PV modules into the state. ${ }^{196}$

The Department of Environmental Quality established a stakeholder process, required by the Act, to inform a regulatory program for decommissioned PV system equipment. ${ }^{197}$ The Department of Environmental Quality and the Environmental Management Commission were required to submit quarterly joint interim reports on their activities and progress to the General Assembly. ${ }^{198}$ On January 1, 2021, the Department of Environmental Quality issued a final report on the Commission's findings. In the final report, the Environmental Management Commission:

- Found that North Carolina currently has more than 4,000 MW of installed solar capacity and that figure is expected to double in the next five years

- Estimated that 8.5 million PV modules will be decommissioned between 2036 and 2040

\footnotetext{
194 “'Utility-scale solar project means a ground-mounted PV, concentrating PV, or concentrating solar power project directly connected to the electrical grid that generates electricity for sale. The term includes the solar arrays, accessory buildings, transmission facilities, and any other infrastructure necessary for the operation of the project. The term does not include renewable energy facilities owned or leased by a retail electric customer intended primarily for the customer's own use to offset the customer's own retail electricity consumption at the premises" (2019 N.C. Sess. Law 2019-132).

1952019 N.C. Sess. Law 2019-132

1962019 N.C. Sess. Law 2019-132

1972019 N.C. Sess. Law 2019-132

1982019 N.C. Sess. Law 2019-132
} 
- Found that recycling capacity for solar PV modules is nascent and noted that in the future, sufficient infrastructure to support transportation and recycling of EoL PV modules will need to be developed

- Suggested the creation of an online list of in-state and out-of-state energy equipment recyclers

- Emphasized the benefits of reuse and recycling of PV modules to reduce waste by establishing the following order of preference for management of retired and EoL PV modules: 1) direct reuse, 2) refurbishment/repair for reuse, 3) recycling if reuse and repair for reuse are not feasible, and 4) disposal

- Stated that the Department of Environmental Quality, in consultation with the EPA, will begin rulemaking to define EoL PV modules as a universal waste. The Commission noted that the purpose of PV universal waste regulations was to facilitate recycling, provide regulatory clarity, and eliminate the need to conduct TCLP testing on EoL PV modules

- Found that EoL PV modules that exhibit hazardous characteristics under the TCLP test should be classified and managed as hazardous waste, all others may be managed as solid waste

- Requested that the American Society for Testing and Materials (ASTM) develop a sample preparation procedure for use in TCLP testing of PV modules for representative and accurate waste characterization due to inconsistency and variability concerns associated with TCLP testing results

- Found that establishment of a fee system paid for by manufacturers to support a stewardship program may create a disincentive for recycling, especially given the lack of accessible recycling facilities (NCDEQ 2021).

Consideration: Potential advantages associated with North Carolina's policy are that it required a study to consider reuse and PV EoL management options - including recycling - as well as associated barriers, which may inform the development of new regulations (NCDEQ 2021). In addition, the Commission established an order of preference for the management of EoL PV modules, which emphasizes the benefits of reuse and recycling (NCDEQ 2021). Moreover, the Commission noted the inconsistent results of the TCLP and requested ASTM develop a sample procedure specific to PV modules (NCDEQ 2021). However, as the Commission noted, current infrastructure is insufficient to support cost effective and efficient transportation and recycling of EoL PV modules (NCDEQ 2021). In addition, the Commission is considering the development of universal waste regulations, which often treat recycling and disposal in the same manner and therefore may not provide an incentive for recycling EoL PV modules under current market conditions.

\subsubsection{California}

In September 2020, the DTSC enacted regulation R-2017-04, which allows for discarded PV modules ${ }^{199}$ that are hazardous waste (due to toxicity) to be managed as universal waste in California. ${ }^{200}$ California's universal waste regulations include notification, reporting, handling,

\footnotetext{
199 The term "PV modules" "includes integrated components that cannot be separated without breaking the module glass," which can include "the protective glass, conductive metal contact, metal framing the PV cells,...and the top and back layer (Cal. Code Regs. tit. 22 66260.10). A PV module is "discarded" or considered waste when it is abandoned, relinquished, or becomes a recyclable material (Cal. Code Regs. tit. $22 \S 66273.7 .1$ ).

${ }^{200}$ Cal. Code Regs. tit. $22 \S 66273.7 .1$
} 
storage, and transportation requirements that are less stringent than California's hazardous waste regulations. ${ }^{201}$ DTSC regulations:

- Clarify that PV modules that are refurbished or reused are not waste and not subject to the universal waste regulations;

- State that a party who is subject to an enforcement action who claims that a PV module is not waste bears the burden of demonstrating that there is a known market or disposition for its use as a PV module;

- Clarify that a PV module becomes "waste" on the date it is discarded (PV panels that are abandoned, relinquished, or recycled are considered waste when they are disconnected or removed from service) (DTSC n.d.);

- Establish universal waste requirements for universal waste handlers (e.g., asset owners, installers, manufacturers, distributors/warehouses, storage facilities, recyclers, treatment facilities) and universal transporters that generate, accumulate, treat, transport or dispose of PV modules that exhibit toxicity characteristics of hazardous waste; and

- Specify the management standards for different levels of treatment to ensure treatment is performed safely by universal waste handlers that do not have a hazardous waste facility permit that they would otherwise be required to obtain. ${ }^{202}$

The DTSC regulations authorize and require universal waste handlers ${ }^{203}$ to:

- Collect, store, and accumulate PV modules for up to one year after which they must be transported to a destination facility for disposal ${ }^{204}$

- Remove replaceable components, such as batteries, inverters, cables, connectors from a PV system, without breaking PV module glass ${ }^{205,206}$

- Dismantle separate components from the PV module (e.g., metal frames) without breaking PV module glass ${ }^{207}$

- With separate prior authority from the DTSC, process PV modules by intentionally breaking the PV module glass 208, 209

${ }^{201}$ Cal. Code Regs. tit. $22 \S \S 66273.1-66273.84$

${ }^{202}$ Cal. Code Regs. § 66273.75

${ }^{203}$ Under California law, a universal waste handler is defined as (1) "any person, by site, whose act or process produces [universal waste] or whose act first cases a [universal waste] to become subject to regulation," (2) "the owner or operator of a facility, including all contiguous property, that receives universal waste from other universal waste handlers, accumulates universal waste, and sends universal waste to another universal waste handler, to a destination facility, or to a foreign destination; or (3) the owner or operator of a facility who is authorized to treat universal waste" (Cal. Code Regs. tit. $22 \S \S 66260.10,66273.9$ ).

${ }^{204}$ Cal. Code Regs. tit. $22 \S 66273.35(2020)$

${ }^{205}$ Cal. Code Regs. tit. $22 \S 66273.71$ (2020)

${ }^{206}$ A PV system includes the PV module and any ancillary components that can be manually separated without breaking the PV module glass (e.g., metal frames, connectors, junction boxes, batteries, inverters, wires, cables) (Cal. Code Regs. tit. $22 \S 66260.10$ [2020])

${ }^{207}$ Cal. Code Regs. tit. $22 \S 66273.72$ [2020])

${ }^{208}$ Cal. Code Regs. tit. $22 \S 66273.73$ [2020])

${ }^{209}$ Universal waste handlers who intentionally break PV modules require authorization from the DTSC (Cal. Code Regs. tit. $22 \S 66273.73$ [2020]). However, universal waste handlers who remove replaceable components or dismantle PV module components without breaking the module do not require authorization from the DTSC to conduct those activities (Cal. Code Regs. tit. $22 \S \S 66273.71,66273.72$ [2020]). 
- Comply with notification, annual reporting, and recordkeeping requirements (e.g., onetime notification to the DTSC, which includes information regarding types of modules collected, source of the PV modules, and an indication as to whether the handler plans on accumulating more than $5,000 \mathrm{~kg}$ (approximately 11,023 pounds) or more $\mathrm{PV}$ modules at one time) 210,211

- Comply with requirements prohibiting disposal of universal waste PV modules except for disposal at a universal waste destination facility;

- Comply with specified labeling requirements (e.g., each PV module or container or pallet in or on which PV modules are contained); and

- Comply with requirements prohibiting dilution or treating universal waste PV modules except for responding to releases or by following the requirements of the universal waste regulations ${ }^{212,213,214}$

The DTSC universal waste regulations for PV modules also:

- Restrict universal waste transporters ${ }^{215}$ from transporting more than 220 pounds of PV modules (approximately 5 modules) at any one time, unless the PV modules are packaged in a manner prescribed by the regulations which prevents leakage, breakage, or release of any constituent part of a PV module; ${ }^{216}$

- Prohibit universal waste transporters from storing universal waste PV modules at a transfer facility for longer than 10 days in industrial zoned areas and for more than 6 days in other zoned areas; ${ }^{217}$

- Prohibit universal waste transporters from transporting universal waste PV modules to a place other than a universal waste handler, a universal waste destination facility, or a foreign destination; ${ }^{218}$ and

- Restrict universal waste handlers and universal waste destination who treat universal waste PV modules from using chemicals or heat to process PV modules without a hazardous waste facility permit (restricts to physical/mechanical technologies). ${ }^{219,} 220$

Consideration: A potential advantage to the California universal waste regulations is that it may reduce some of the costs and liabilities associated with collecting, storing, and transporting discarded hazardous PV modules (as compared to fully-regulated hazardous waste) and may deter the abandonment of PV modules, which are characterized as hazardous under California law (CPUC

${ }^{210}$ Cal. Code Regs. tit. $22 \S 66273.32(2020)$

${ }^{211}$ Cal. Code Regs. tit. $22 \S 66273.32$ (2020) (Universal waste handlers that accept more than 220 pounds of PV modules (approximately 5 modules) at one time, must submit an annual report to the DTSC including information about the total quantity of modules handled, a list of locations the handler shipped modules to the previous year, and how each of those locations intend to manage the PV modules (e.g., recycle or disposal)).

${ }^{212}$ Cal. Code Reg. tit. $22 \S \S 662.9-.10(2020)$

${ }^{213}$ Cal. Code Reg. tit. $22 \S 66273.35$ (2020)

${ }^{214}$ Cal. Code Reg. tit. $22 \S \S 66273.71-.73$ (2020)

215 "Universal waste transporter" means a person engaged in the offsite transportation of universal waste by air, rail, highway, or water (Cal. Code Regs. § 66273.9).

${ }^{216}$ Cal. Code Regs. tit. $22 \S \S 66273.33 .6,66273.51$ (2020)

${ }^{217}$ Cal. Code Regs. § 66273.53

${ }^{218}$ Cal. Code Regs. $§ 66273.55$

${ }^{219}$ Cal. Code Regs. § 66273.73

${ }^{220}$ CSSA 2020, presentation by Chosu Khin, DTSC 
2019b, DTSC 2019a, Cal. Code Regs. tit. 22 §§ 66273.1-66273.84). However, some industry stakeholders have warned that the universal waste regulations may also act as a barrier to recycling PV modules within the state of California (CSSA 2020; ASES 2020). For instance, under the DTSC universal waste regulations, universal waste handlers and universal waste destination facilities are prohibited from using heat or chemicals to treat PV modules, which are processes used in most module recycling today (e.g., extracting embedded metals from the glass) (CSSA 2020; ASES 2020; Cal. Code Reg. $\S \S 66273.71,66273.71,66273.73(2020)$ ). In addition, the DTSC universal waste regulations treat disposal and recycling of hazardous PV modules in the same manner (e.g., the same handling, storing, transportation requirements and associated liabilities for non-compliance) (Cal. Code Reg. tit. §66273.7.1 (2020)). Accordingly, under the DTSC universal waste regulations, disposal may remain the most economically favorable and accessible method for EoL management of discarded PV modules in California (CSSA 2020; ASES 2020).

\subsection{Proposed (Pending) Legislation}

This section summarizes proposed, but not-yet enacted, U.S. legislation that addresses reuse and EoL management options for PV system equipment. As of February 2021, no proposed U.S. federal legislation expressly speaks to repair/reuse/recycling or disposal of PV system equipment. However, bills in the legislatures of California, Hawaii, and Rhode Island address reuse and EoL management options for PV system equipment. These proposals are diverse regulatory frameworks that cover different lifecycle activities and actors in the PV value chain.

\subsubsection{California}

If enacted, California's Senate Bill 207, which was introduced January 1, 2021, would require the state's Secretary for Environmental Protection to convene a Photovoltaic Recycling Advisory Group that would study and recommend potential policies to the state legislature to ensure safe and cost-effective reuse or recycling for as many PV modules as possible in California. ${ }^{221}$ The Secretary for Environmental Protection must appoint members from specific sectors of the PV industry, which are:

- The Director of Resources Recycling and Recovery or their designee,

- The Director of Toxic Substance Control or their designee,

- A photovoltaic panel or solar energy system manufacturer,

- An organization that represents one or more photovoltaic panel manufacturers,

- An electronic waste recycler or an organization that represents one or more electronic waste recyclers,

- A photovoltaic panel or solar energy system repair dealer or an organization that represents one or more photovoltaic panel or solar energy system repair dealers,

- An environmental organization that specializes in waste reduction and recycling,

- A representative of the solar industry, and

- A standards organization that has a focus on photovoltaic or electrical engineering. ${ }^{222}$

${ }^{221}$ S.B. 207, 2021-2022 Leg., Reg. Sess. (Cal. 2021)

${ }^{222}$ S.B. 207, 2021-2022 Leg., Reg. Sess. (Cal. 2021) 
The bill would require the group to meet for the first time no later than April 1, 2022 and submit its policy recommendations to the legislature no later than April 1, 2025. ${ }^{223}$ Consultations with any relevant entities would be required to inform the group's final recommendations. ${ }^{224}$

\subsubsection{Hawaii}

If enacted, Hawaii's House Bill 1333, which was introduced January 27, 2021, would require the Hawaii State Energy Office to work with the Hawaii State Department of Health on a comprehensive study to determine best practices for disposing of and recycling discarded clean energy products, including PV modules, glass, frames, wiring, inverters, and batteries. ${ }^{225}$ Like North Carolina's law, the bill would require a study to address specific questions, including:

- "The amount of aging PV and solar water heater panels in the State that will need to be disposed of or recycled

- Other types of clean energy materials expected to be discarded in Hawaii in significant quantities, including glass, frames, wiring, inverters, and batteries

- The type and chemical composition of those clean energy materials

- Best practices for collection, disposal, and recycling of those clean energy materials

- Whether a fee should be charged for disposal or recycling of those clean energy materials

- Any other issues that the Hawaii State Energy Office and the Department of Health consider appropriate for management, recycling, and disposal of those clean energy materials." 226

The Hawaii State Energy Office would be required to submit an interim report on the study's progress to the legislature in 2022 and a final report in $2023 .{ }^{227}$ The final report must include findings, recommendations, and any proposed legislation resulting from the study. ${ }^{228}$ A subsection of the bill would appropriate money from the general state revenues to support the purposes of the bill, but the exact amount is yet to be determined. ${ }^{229}$ The bill, if enacted, would not go into effect until July 1, 2021. ${ }^{230}$

\subsubsection{Rhode Island}

If enacted, Rhode Island's House Bill 5525, which was introduced on February 12, 2021, would create a Photovoltaic Module Stewardship and Takeback Program, similar to Washington's law, requiring PV module manufacturers ${ }^{231}$ to finance and implement a takeback and recycling or

${ }^{223}$ S.B. 207, 2021-2022 Leg., Reg. Sess. (Cal. 2021)

${ }^{224}$ S.B. 207, 2021-2022 Leg., Reg. Sess. (Cal. 2021)

${ }^{225}$ H.B. 1333, 31st Leg., Reg. Sess. (Haw. 2021)

${ }^{226}$ H.B. 1333, 31st Leg., Reg. Sess. (Haw. 2021)

${ }^{227}$ H.B. 1333, 31st Leg., Reg. Sess. (Haw. 2021)

${ }^{228}$ H.B. 1333, 31st Leg., Reg. Sess. (Haw. 2021)

${ }^{229}$ H.B. 1333, 31st Leg., Reg. Sess. (Haw. 2021)

${ }^{230}$ H.B. 1333, 31st Leg., Reg. Sess. (Haw. 2021)

231 ''Manufacturer' means any person in business or no longer in business but having a successor in interest who, irrespective of the selling technique used, including by means of distance or remote sale: (i) manufactures or has manufactured a PV module under its own brand names for sale in or into this state; (ii) assembles or has assembled a PV module that uses parts manufactured by others for sale in or into this state under the assembler's brand names; (iii) resells or has resold in or into this state under its own brand names a PV module produced by other suppliers, including retail establishments that sell PV modules under their own brand names; (iv) manufactures or has 
reuse stewardship plan for PV modules sold in or into Rhode Island after July 1, 2021, at no cost to owners. ${ }^{232}$ The Bill specifies that the Department of Environmental Management must develop and implement guidance to aid manufacturers in preparing and implementing selfdirected stewardship plans by July 1, 2022. ${ }^{233}$ Beginning July 1, 2023, no manufacturer, distributor, retailer, or installer would be able to sell or offer PV modules ${ }^{234}$ for sale within or into Rhode Island unless the manufacturer of the PV module had submitted a stewardship plan to the Department of Environmental Management and obtained approval. PV modules covered by the program would include PV modules that are:

- "Are installed on, connected to, or integral with buildings;

- Are used as components of freestanding, off-grid, power generation systems, such as for powering water pumping stations, electric vehicle charging stations, fencing, street and signage lights, and other commercial or agricultural purposes; or

- Are part of a system connected to the grid or utility service."235

Manufacturers would have to submit a stewardship plan to the Department of Environmental Management and implement the plan by July 1, 2022. ${ }^{236}$ In lieu of developing a plan individually, manufacturers would also have the option to join a registered stewardship organization and allow that organization to create and implement the plan on the manufacturer's behalf. ${ }^{237}$ The stewardship plan must outline how the manufacturer will:

- Finance the takeback program

- Accept all their PV modules sold within or into the state after July 1, 2021

- Minimize the release of hazardous substances and maximize the recovery of other components

- Provide convenient takeback opportunities in each county of Rhode Island where its modules are used

- Disseminate applicable information about its program to relevant stakeholders

- Implement performance goals to reuse and/or recycle at least $85 \%$ of the PV modules the manufacturer collects. ${ }^{238}$

After initial approval of the stewardship plans, the manufacturer would have to submit and publish annual reports about the previous year's implementation of the manufacturer's plan, starting in 2024. ${ }^{239}$ The annual reports would have to include achievement assessments of the plan's performance goals and could include recommendations to the Department of

manufactured a cobranded PV module product for sale in or into this state that carries the name of both the manufacturer and a retailer; (v) imports or has imported a PV module in the U.S. that is sold in or into the state; (vi) sells at retail a PV module acquired from an importer that is the manufacturer; or (vii) elects to assume the responsibility and register in lieu of a manufacturer" (H.B. 5525, 2021 Leg., Reg. Sess. [R.I. 2021]).

${ }^{232}$ H.B. 5525, 2021 Leg., Reg. Sess. (R.I. 2021)

${ }^{233}$ H.B. 5525, 2021 Leg., Reg. Sess. (R.I. 2021)

${ }^{234}$ H.B. 5525, 2021 Leg., Reg. Sess. (R.I. 2021)

${ }^{235}$ H.B. 5525, 2021 Leg., Reg. Sess. (R.I. 2021)

${ }^{236}$ H.B. 5525, 2021 Leg., Reg. Sess. (R.I. 2021)

${ }^{237}$ H.B. 5525, 2021 Leg., Reg. Sess. (R.I. 2021)

${ }^{238}$ H.B. 5525, 2021 Leg., Reg. Sess. (R.I. 2021)

${ }^{239}$ H.B. 5525, 2021 Leg., Reg. Sess. (R.I. 2021) 
Environmental Management or the Rhode Island Legislature on potential modifications to improve the effectiveness of the takeback program. ${ }^{240}$

The Department of Environmental Management could collect a flat fee from every participating manufacturer to cover the costs of administering the program and an annual fee from each manufacturer based on the manufacturer's pro rata share of the preceding year's PV module sales in Rhode Island. ${ }^{241}$ The Department of Environmental Management could, after issuing a warning of non-compliance, impose a penalty of up to $\$ 10,000$ per sale of a PV module in Rhode Island. ${ }^{242}$ The Department of Environmental Management would have to deposit all fees and penalties into a PV module recycling account that could only be used to fund the program's administration costs. ${ }^{243}$

The Department of Environmental Management would also have to develop guidance for manufacturers that explains how to prepare and implement a stewardship plan. ${ }^{244}$ The Department of Environmental Management would have to establish a process to develop the guidance by January 1, 2022 and complete the guidance by July 1, 2022. ${ }^{245}$

\subsection{State-Led Initiatives}

State-led initiatives developed in Illinois, Minnesota, and California address repair/reuse/recycling and disposal of PV system equipment. The Illinois Sustainable Technology Center (ISTC), at the University of Illinois, launched a Solar Panel Recycling Initiative in 2017 in response to the Illinois Future Jobs Act of 2016 that requires a significant increase in PV capacity, in addition to projections of near-term EoL PV (Holm and Martin 2019). As part of the initiative, ISTC in conjunction with the Illinois Environmental Protection Agency, formed a PV EoL management stakeholder working group of experts across various sectors to identify and evaluate barriers to integrating PV into the circular economy. The group's intention is to develop technical and economic solutions that will enable environmentally sustainable reuse and EoL PV management decisions and the recovery of valuable resources in Illinois (ISTC n.d.). Similarly, in 2019, the Minnesota Pollution Control Agency, the Minnesota Department of Commerce, and the Minnesota Solar Energy Industries Association formed a working group to help develop policy, financial, and technical solutions for environmentally sustainable PV materials management options (Minnesota Department of Commerce 2019; Minnesota Solar Panel Recycling Strategy Working Group 2019). The working group was formed in response to the steady growth of installed PV capacity in Minnesota, in addition to projections of near-term EoL PV (Minnesota Department of Commerce 2019; Minnesota Solar Panel Recycling Strategy Working Group 2019). In addition, in 2019, the California Public Utilities Commission (CPUC) and the California Department of Resources Recycling and Recovery (CalRecycle) signed a Memorandum of Understanding to cooperate on the development of consistent approaches to waste from PV modules and related equipment, including inverters (CPUC and CalRecycle 2019). As of January 2021, the California Energy

\footnotetext{
${ }^{240}$ H.B. 5525, 2021 Leg., Reg. Sess. (R.I. 2021)

${ }^{241}$ H.B. 5525, 2021 Leg., Reg. Sess. (R.I. 2021)

${ }^{242}$ H.B. 5525, 2021 Leg., Reg. Sess. (R.I. 2021)

${ }^{243}$ H.B. 5525, 2021 Leg., Reg. Sess. (R.I. 2021)

${ }^{244}$ H.B. 5525, 2021 Leg., Reg. Sess. (R.I. 2021)

${ }^{245}$ H.B. 5525, 2021 Leg., Reg. Sess. (R.I. 2021)
} 
Commission and the California Air Resources Board are also planning to sign onto the 2018 CPUC and CalRecycle memorandum. ${ }^{246,247}$

\section{Case Studies}

In this section, we present case studies of three U.S. solar industry business models for the repair/reuse/recycling of PV system equipment: an American solar PV module manufacturer that offers CdTe PV module collection and recycling services; a nonprofit that sells used c-Si PV modules and BOS equipment at discounted rates for secondary use and installs PV systems for charitable projects; and a solar consulting company that sells used and repaired c-Si PV modules and BOS equipment at discounted rates for secondary use and coordinates the recycling of decommissioned modules.

\subsection{First Solar}

First Solar, Inc. is an American solar PV module manufacturer headquartered in Arizona that offers PV module collection and recycling services. Founded in 1999, First Solar has become not only the largest thin-film CdTe PV module manufacturer in the world - with more than $20 \mathrm{GW}$ installed in more than 35 countries - but also an industry leader in sustainable business practices (Beetz 2019; First Solar 2019). First Solar has global recycling facilities in Ohio, Germany, Malaysia, and Vietnam; the recycling facilities in Ohio, Vietnam, and Malaysia are collocated with First Solar's manufacturing operations. ${ }^{248}$ Globally, First Solar has recycled approximately 14,000-25,500 Mt of PV module scrap annually since 2015 from its manufacturing operations, customer warranty returns, and module collection and recycling program. ${ }^{249}$

In 2005, First Solar developed the solar industry's first global module collection and recycling program. First Solar created the program to improve the company's sustainability practices and to reduce manufacturing costs by recovering semiconductor materials (e.g., $\mathrm{Cd}$ and $\mathrm{Te}$ ) for reuse in the production of new modules and glass for reuse in new glass products. ${ }^{250}$ Over the years First Solar has improved the collection and recycling program by proactively investing in enhancements to its recycling technology and the administration of the program to maximize the amount of material recycled (Sinha et al. 2018).

The first version of the collection and recycling program was designed as a voluntary prefunded model in which part of the PV module's sale price went into a recycling trust to fund collection and recycling operations. ${ }^{251}$ First Solar estimated future costs of collecting and recycling a module at the end of its life and added that cost estimate to the sale price of the module. First Solar module agreements, at this time, specified that when the modules were taken out of service they would be processed under First Solar's collection and recycling program at no additional cost to the customer (Krueger 2010).

\footnotetext{
${ }^{246}$ Paulina Kolic, CalRecycle, email, September 6, 2019

247 Teresa Bui, CalRecycle, email, January 8, 2021

${ }^{248}$ Matthew Garamone, and Parikhit Sinha, First Solar, teleconference, August 26, 2019

${ }^{249}$ Parikhit Sinha, First Solar, email, August 26, 2019

${ }^{250}$ Parikhit Sinha, First Solar, email, August 26, 2019

${ }^{251}$ Matthew Garamone and Parikhit Sinha, First Solar, teleconference, August 26, 2019
} 
In 2012, First Solar modified the collection and recycling program framework, moving away from the prefunded model to a more flexible pay-as-you-go model that is still used today. The voluntary pay-as-you-go program model allows customers to decide whether and when they want to employ First Solar's recycling services. The pay-as-you-go model does not impact the upfront costs of the modules' purchase price, and it allows customers to request recycling services on a per-unit basis. Customers may request on-demand service for a single-event or consolidate recycling requests by entering into a two-year renewable service contract at any time (e.g., at the time of purchase or at the time of decommissioning). The two-year renewable service contract is a competitive, cost-effective option that is based on current costs of recycling operations, which have seen efficiency gains over the years. ${ }^{252}$

First Solar's has invested in improvements to its recycling technology over the years to increase recycling capacity, maximize the amount of material recycled, and drive down overall recycling costs. First Solar's first-generation recycling technology was based on mining industry technology and involved moving glass and liquid from process to process, which had a modest maximum capacity rate of 10 Mt per day (Sinha et al. 2018). In 2011, First Solar rolled out its second-generation recycling technology based on the chemical industry's batch process technology, which involved circulating liquids within scalable reactor columns and improved the capacity limits to $30 \mathrm{Mt}$ per day (Sinha et al. 2018). In 2015, First Solar introduced its thirdgeneration technology, which is still used today. First Solar's third-generation technology is a continuous-flow process that has increased recovery rates up to $90 \%$, increased purity levels for glass and semiconductor materials recovery, and increased the daily capacity rates from $30 \mathrm{Mt}$ to $150 \mathrm{Mt}$ (Sinha et al. 2018).

In practice, First Solar's collection and recycling program requires customers to either transport modules to a designated recycling center or collection point or pay an additional fee for First Solar to collect and transport the modules on the customer's behalf. Once a module is received, First Solar pretreats it to remove the junction box and cable assembly, and the aluminum frame, if applicable. The remaining glass module is put into a shredder to begin the recycling process. First Solar may also donate or resell new production line modules that have cosmetic blemishes or a lower wattage than warrantied and are unsuitable for the primary market. First Solar recycles modules that do not have a reuse value, and it recovers over $90 \%$ of the glass and semiconductor materials for use in the production of new cadmium telluride modules. ${ }^{253}$

\subsection{Good Sun}

Good Sun is a 501(c)(3) nonprofit headquartered in California that sells used c-Si PV modules and BOS equipment at discounted rates for secondary use and installs PV systems for charitable projects in low- and moderate-income (LMI) communities. Good Sun was founded in 2013 by licensed PV system installers who saw an opportunity to not only to divert operational modules from the landfill but also increase PV deployment by providing access to LMI communities traditionally underserved by the solar industry (Good Sun 2019). ${ }^{254}$ Good Sun uses the profits from the sale of the used PV modules and BOS equipment to install PV systems and provide vocational training for LMI communities in California and Africa. Since 2017, Good Sun has

\footnotetext{
252 Matthew Garamone and Parikhit Sinha, First Solar, teleconference, August 26, 2019

${ }^{253}$ Matthew Garamone and Parikhit Sinha, First Solar, teleconference, August 26, 2019

${ }^{254}$ Eric Stikes and Vince Lucia, Good Sun, teleconference, August 26, 2019
} 
sold more than 2,500 used PV modules, diverting more than 90,000 pounds of solar panels from landfills and raising more than $\$ 200,000$ for charitable projects. ${ }^{255}$

In 2019, Good Sun received approximately 2,700 donated ex-service PV modules from PV module manufacturers, equipment suppliers, O\&M entities, installers, and PV system owners. Good Sun typically picks up the used PV modules from the donation site and transports them to their facility where they perform a spot check to evaluate the modules' condition. The PV module's condition dictates its reuse applications or EoL treatment. PV modules that are not in sufficient condition for reuse are sent to either Recycle PV (a recycling company) for resource recovery or a local solid waste transfer station. ${ }^{256}$

The donated PV modules often come from projects where the end user found it advantageous to replace older operational PV modules with newer, more efficient modules. Most of the used PV modules are approximately 10 years old and have $60 \%-70 \%$ of their original capacity remaining. Good Sun resells early retired modules at a cost that is proportionate to their remaining capacity, and the profits are used to support charitable project work. Typically, these PV modules are best suitable for ground-mount grid-tied and off-grid applications in addition to rooftop off-grid applications in California (Good Sun 2019). ${ }^{257,258,259}$

Good Sun also receives lightly used test, or blemished, PV modules that are not suited for the primary market ${ }^{260}$ from partners, such as U.S.-based PV module manufacturer SunPower (Good Sun 2019). ${ }^{261,262}$ Good Sun typically uses these higher-efficiency PV modules for direct reuse in ground-mount grid-tied and off-grid charitable projects in California and rooftop and groundmount grid-tied and off-grid charitable projects in other U.S. states and in Africa. Charity project installations also serve as educational and vocational training tools for LMI communities. During installation, Good Sun trains aspiring solar professionals to help prepare them for jobs in the solar industry. Completed PV systems also serve as a demonstration lab providing hands-on learning opportunities. ${ }^{263,264}$ Good Sun charitable projects include PV system installations at a homeless shelter, several Habitat for Humanity homes, several charter schools in northern California, and an orphanage, a school, and a hospital in Africa (Good Sun 2019). Table 8 lists some of Good Sun's charitable projects.

\footnotetext{
${ }^{255}$ Eric Stikes, Good Sun, email, May 3, 2019

${ }^{256}$ Eric Stikes and Vince Lucia, Good Sun, teleconference, August 26, 2019

${ }^{257}$ Because rooftop PV module installations in California must comply with California Department of Forestry and Fire Protection regulations, which are discussed in more detail in Section 3.2.

${ }^{258}$ Eric Stikes, Good Sun, email, May 3, 2019

${ }^{259}$ Eric Stikes and Vince Lucia, Good Sun, teleconference, August 26, 2019

${ }^{260}$ These modules typically have a blemish or damage, such as a scratch in the glass or a bent frame, that makes the modules "undesirable" to many consumers and, therefore, unsuitable for sale as a new module (Eric Stikes, Good Sun, email, January 22, 2020).

${ }^{261}$ Eric Stikes, Good Sun, email, May 3, 2019

262 Eric Stikes and Vince Lucia, Good Sun, teleconference, August 26, 2019

${ }^{263}$ Eric Stikes, Good Sun, email, May 3, 2019

${ }^{264}$ Eric Stikes and Vince Lucia, Good Sun, teleconference, August 26, 2019
} 
Table 8. Good Sun Projects

\begin{tabular}{|c|c|c|c|c|}
\hline $\begin{array}{l}\text { Project Name } \\
\text { and Location }\end{array}$ & Project Summary & $\begin{array}{l}\text { Estimated System Value } \\
\text { and Costs }\end{array}$ & $\begin{array}{l}\text { Estimated } \\
\text { Savings }\end{array}$ & $\begin{array}{l}\text { System Size } \\
\text { and Details }\end{array}$ \\
\hline Habitat for Humanity & \multirow{2}{*}{$\begin{array}{l}\text { Four homes: Rooftop grid-tied PV } \\
\text { systems to help } 4 \text { low-income } \\
\text { families reduce utility costs }\end{array}$} & System Value: $\$ 40,000$ & Annual: $\$ 3,500$ & $10.4 \mathrm{~kW} D C$ \\
\hline Grass Valley, CA, USA & & $\begin{array}{l}\text { Total Cost to Habitat for } \\
\text { Humanity: } \$ 12,000\end{array}$ & $\begin{array}{l}\text { Lifetime: } \\
>\$ 150,000\end{array}$ & $\begin{array}{l}30 \text { SunPower } 345-\mathrm{W} \\
\text { modules, } 30 \text { Enphase } \\
\text { microinverters }\end{array}$ \\
\hline \multirow{2}{*}{$\begin{array}{l}\text { Grass Valley Charter } \\
\text { Solar Install } \\
\text { Grass Valley, CA, USA }\end{array}$} & \multirow{2}{*}{$\begin{array}{l}\text { Ground-mounted PV system to help } \\
\text { more than } 200 \text { LMI families, cut } \\
\text { utility costs for the school, and } \\
\text { provide educational demonstration } \\
\text { and training opportunities for } \\
\text { students }\end{array}$} & System Value: $\$ 55,000$ & Annual: $\$ 6,000$ & $10.4 \mathrm{~kW}$ \\
\hline & & Total Cost to School: $\$ 0$ & $\begin{array}{l}\text { Lifetime: } \\
>\$ 150,000\end{array}$ & $\begin{array}{l}30 \text { SunPower } 345-W \\
\text { modules, } 2 \text { SolarEdge } \\
\text { inverters }\end{array}$ \\
\hline \multirow{2}{*}{$\begin{array}{l}\text { Hospitality House } \\
\text { Homeless Shelter } \\
\text { Grass Valley, CA, USA }\end{array}$} & \multirow{2}{*}{$\begin{array}{l}\text { Rooftop grid-tied PV system to help } \\
\text { more than } 200 \text { LMI families and cut } \\
\text { utility costs for the homeless shelter }\end{array}$} & System Value: $\$ 50,000$ & Annual: $\$ 4,500$ & $14 \mathrm{~kW}$ DC \\
\hline & & $\begin{array}{l}\text { Total Cost to Homeless } \\
\text { Shelter: } \$ 2,800\end{array}$ & $\begin{array}{l}\text { Lifetime: } \\
>\$ 150,000\end{array}$ & $\begin{array}{l}35 \text { SunPower } 345-\mathrm{W} \\
\text { modules, } 5 \text { SunPower } \\
360-\mathrm{W} \text { modules, } \\
11.4 \mathrm{~kW} \text { SolarEdge HD } \\
\text { inverter }\end{array}$ \\
\hline \multirow{2}{*}{$\begin{array}{l}\text { Yuba River Charter } \\
\text { Preschool Solar } \\
\text { Install } \\
\text { Grass Valley, CA, USA }\end{array}$} & \multirow{2}{*}{$\begin{array}{l}\text { Ground-mounted PV system to help } \\
\text { more than } 200 \text { LMI families, cut } \\
\text { utility costs for the school, and } \\
\text { provide educational demonstration } \\
\text { and training opportunities for } \\
\text { students }\end{array}$} & System Value: $\$ 65,000$ & Annual: $\$ 6,000$ & $11 \mathrm{~kW}$ \\
\hline & & Total Cost to School: $\$ 2,000$ & $\begin{array}{l}\text { Lifetime: } \\
>\$ 150,000\end{array}$ & $\begin{array}{l}32 \text { SunPower } 345-W \\
\text { modules, SolarEdge } \\
\text { HD inverter }\end{array}$ \\
\hline \multirow{2}{*}{$\begin{array}{l}\text { Bitney College Prep } \\
\text { School Solar } \\
\text { Grass Valley, CA, USA }\end{array}$} & \multirow{2}{*}{$\begin{array}{l}\text { Rooftop grid-tied PV system will } \\
\text { help } 85 \text { LMI families, cut utility costs } \\
\text { for the school, and provide } \\
\text { educational opportunities for } \\
\text { students }\end{array}$} & System Value: $\$ 57,000$ & Annual: $\$ 6,000$ & $12 \mathrm{~kW}$ DC \\
\hline & & Total Cost to School: $\$ 0$ & $\begin{array}{l}\text { Lifetime: } \\
>\$ 150,000\end{array}$ & $\begin{array}{l}34 \text { SunPower } 350-W \\
\text { solar modules, } \\
\text { SolarEdge inverters }\end{array}$ \\
\hline Cura Orphanage & \multirow{2}{*}{$\begin{array}{l}\text { Small solar charging system for } \\
\text { emergency lighting and USB }\end{array}$} & System Value: $\$ 1,000$ & Annual: N/A & $160 W_{D C}$ \\
\hline Nairobi, Kenya & & Total Cost to Orphanage: $\$ 0$ & Lifetime: N/A & \\
\hline
\end{tabular}




\begin{tabular}{|c|c|c|c|c|}
\hline $\begin{array}{l}\text { Project Name } \\
\text { and Location }\end{array}$ & Project Summary & $\begin{array}{l}\text { Estimated System Value } \\
\text { and Costs }\end{array}$ & $\begin{array}{l}\text { Estimated } \\
\text { Savings }\end{array}$ & $\begin{array}{l}\text { System Size } \\
\text { and Details }\end{array}$ \\
\hline & $\begin{array}{l}\text { devices to help } 20 \text { LMI families and } \\
\text { provide security lighting }\end{array}$ & & & $\begin{array}{l}280-\text { W solar modules, } \\
16 \text { LED lights, } 2 \text { lithium- } \\
\text { ion batteries, USB } \\
\text { charging }\end{array}$ \\
\hline \multirow{2}{*}{$\begin{array}{l}\text { Queen Elizabeth } \\
\text { Nursery and Primary } \\
\text { School } \\
\text { Kihihi, Uganda }\end{array}$} & \multirow[b]{2}{*}{$\begin{array}{l}\text { Funded construction of four } \\
\text { classrooms, including solar-powered } \\
\text { lighting and communications kit for } \\
\text { each classroom. Provides } \\
\text { approximately } 80 \text { LMI families with } \\
\text { improved educational opportunities } \\
\text { that promote life advancement. }\end{array}$} & System Value: $\$ 1,000$ & Annual: N/A & $160 W_{D C}$ \\
\hline & & Total Cost to School: $\$ 0$ & Lifetime: N/A & $\begin{array}{l}280-W \text { solar modules, } \\
16 \text { LED lights, } 2 \text { lithium- } \\
\text { ion batteries, USB } \\
\text { charging }\end{array}$ \\
\hline \multirow{2}{*}{$\begin{array}{l}\text { Bwindi Community } \\
\text { Hospital } \\
\text { Buhoma, Uganda }\end{array}$} & \multirow{2}{*}{$\begin{array}{l}\text { Portable solar lighting and USB } \\
\text { charging system for remote medical } \\
\text { fieldwork, estimated to help } \\
\text { approximately } 100 \text { LMI families } \\
\text { annually }\end{array}$} & System Value: $\$ 1,000$ & Annual: N/A & $100 W_{D C}$ \\
\hline & & Total Cost to Hospital: $\$ 0$ & Lifetime: N/A & $\begin{array}{l}250-W \text { solar modules, } \\
16 \text { LED lights, } 2 \text { lithium- } \\
\text { ion batteries, USB } \\
\text { charging }\end{array}$ \\
\hline \multirow{2}{*}{$\begin{array}{l}\text { Private Organization } \\
\text { Salt Lake City, Utah, } \\
\text { USA }\end{array}$} & \multirow{2}{*}{$\begin{array}{l}\text { Donation of used solar PV modules } \\
\text { in support of Syrian war refugees }\end{array}$} & System Value: $\$ 15,000$ & Annual: N/A & $20 \mathrm{kWDC}$ \\
\hline & & Total Cost to NGO: $\$ 0$ & Lifetime: N/A & $\begin{array}{l}\text { Assortment of used } \\
\text { solar PV modules of } \\
\text { various wattages }\end{array}$ \\
\hline \multirow{2}{*}{$\begin{array}{l}\text { Private Charity } \\
\text { Florida, USA }\end{array}$} & \multirow{2}{*}{$\begin{array}{l}\text { Donation of } 550 \text { used solar PV } \\
\text { modules in support of Haitian } \\
\text { disaster relief }\end{array}$} & System Value: $\$ 22,000$ & Annual: N/A & $110 \mathrm{~kW}$ DC \\
\hline & & Total Cost to NGO: $\$ 6,500$ & Lifetime: N/A & $\begin{array}{l}550 \text { Used Sanyo 200-W } \\
\text { Solar PV modules }\end{array}$ \\
\hline
\end{tabular}

Source: Good Sun 2019; Cura Orphanage 2019; Eric Stikes, Good Sun, email, January 22, 2020 


\subsection{Recycle PV Solar, LLC}

Recycle PV Solar, LLC (hereinafter Recycle PV) is a solar consulting company headquartered in California that sells used and repaired c-Si PV modules and BOS equipment at discounted rates for secondary use and coordinates the recycling of decommissioned modules to recover valuable materials. Recycle PV was founded in 2011 by solar industry experts who saw an opportunity to divert PV modules from the landfill by selling PV modules to secondary use markets and recycling decommissioned modules to recover valuable materials. ${ }^{265}$

Customers may ship used PV modules to Recycle PV's partner recycling facility in Arizona or Recycle PV can arrange for pick up and transport for an additional fee. Once a module is received, Recycle PV performs a spot-check to evaluate the module's condition and determine its reuse applications or EoL treatment. ${ }^{266}$

Recycle PV sorts used modules into three categories: Batch A, Batch B, and Batch C. Modules designated as Batch $\mathrm{A}$ are usually less than two years old with cosmetic or minor damage. To qualify as Batch A, modules must be physically intact and test within $5 \%$ of their original power specifications. Batch A modules are usually acceptable for almost any type of reuse application, including grid-tied rooftop and ground-mounted installations. Modules designated as Batch B are physically intact but may have additional damage that require physical modifications to the module, such as fixing or replacing bent aluminum frames or damaged connecting electrical wires. To qualify as Batch B, modules must test within $15 \%$ of their original power specifications. If Batch B modules no longer meet UL certification after receiving physical modifications, they are unsuitable for reuse in any grid-tied (e.g., rooftop, ground-mounted) installations. However, these modules may be suitable for off-grid installations that do not require UL certification. Modules designated as Batch C typically have physical damage, such as broken glass, that is not cost-effective to repair. Batch C modules are recycled at Recycle PV's partner recycling facility in Arizona at a cost of $\$ 15$ to 45 per module depending on the module's type, age, and condition. ${ }^{267}$

\section{Conclusion}

The projected volume of early retired and EoL PV equipment in the United States presents not only material management concerns but also domestic resource recovery and secondary market opportunities. Recovered PV material could lead to domestic manufacturing opportunities, reduce resource constraints, and increase supply chain security. PV equipment repair, reuse, and recycling efforts can also reduce negative environmental impacts associated with the lifecycle of a PV module, and lead to new and expanded markets and job creation in the United States.

However, today, there are technical, economic, and regulatory factors that inhibit a circular economy for PV materials in the United States. In short, these factors impact the accessibility and cost effectiveness of repair for reuse, direct reuse, and recycling options for PV equipment in the U.S. and today PV equipment, such as modules are most often disposed of.

\footnotetext{
${ }^{265}$ Sam Vanderhoof, CEO, Recycle PV Solar, LLC, teleconference, September 5, 2019

${ }^{266}$ Sam Vanderhoof, CEO, Recycle PV Solar, LLC, teleconference, September 5, 2019

${ }^{267}$ Sam Vanderhoof, CEO, Recycle PV Solar, LLC, teleconference, September 5, 2019
} 
Policy measures are needed to enable actors along the PV value chain to proactively and collaboratively act to implement environmentally sustainable management decisions for PV. Government-funded R\&D and analysis could lead to the design of more durable, more easily repaired, reused, and recycled PV modules, and to more efficient and cost-effective repair/reuse/recycling products, business models and services. R\&D and analysis could also enable private investment in the early stages of new and expanded PV market opportunities by providing answers to questions that could help alleviate market and regulatory uncertainty. Clearly defined federal and state regulations could mandate and incentivize PV module and BOS equipment reuse and resource recovery. In addition, changes to the current regulatory scheme for managing solid and hazardous waste could reduce the barriers associated with the handling, transport, accumulation, storage, and processing of PV modules and BOS equipment destined for recycling and resource recovery as compared to disposal.

Although the scope of this report is limited to PV circular economy drivers, barriers, and enablers, as well as regulatory and policy considerations in the United States, future research could analyze and address international efforts to repair/reuse/recycle PV system equipment. Future research concerning international efforts aimed at PV module repair/reuse/recycling could further inform efforts in the United States to alleviate market and regulatory uncertainty and expand market opportunities by analyzing the impact of policy and regulatory control already implemented or in development in other countries. In addition, future research analyzing repair/reuse/recycling regulatory and policy initiatives for other products (such as construction material), which have already been implemented, may help further inform our understanding of the drivers, barriers, and enablers to a circular economy for PV materials. 


\section{References}

Ablison Energy. "Average Solar Panel Size, Weight and Dimensions." Accessed February 28, 2020: https://www.ablison.com/average-solar-panel-sizeweight-and-dimensions/.

Alba Energy. "Solar Power FAQs: How Big Is A Solar Panel?" October 15, 2018. https://albaenergy.com/solar-power-faqs-how-big-are-they/.

ASES (American Solar Energy Society). PV Recycling Webinar. October 29, 2020. https://www.gotostage.com/channel/5496676f274b47dfafbdee37cf439cef/recording/239d6df25d ad44a3a7217fc5ed783b58/watch?source=CHANNEL.

Ardani, K., C. Davidson, R. Margolis, and E. Nobler. A State-Level Comparison of Processes and Timelines for Distributed Photovoltaic Interconnection in the United States. NREL/TP7A40-63556. Golden, CO: NREL. January 2015. https://www.nrel.gov/docs/fy15osti/63556.pdf.

Bai, Chunguang, Joseph Sarkis, and Yijie Dou. 2015. "Corporate Sustainability Development in China: Review and Analysis." Industrial Management \& Data Systems115, no.1:5-40. https://www.emerald.com/insight/content/doi/10.1108/IMDS-09-2014-0258/full/html?utm source=TrendMD\&utm $\_$medium $=$cpc\&utm_campaign=Emerald_TrendMD $1 \& W T . m c \_i d=E m e$ rald TrendMD $1 \&$ full $\mathrm{Sc}=1$.

Balfour, John. "PV Plant Repowering, the Utility 50-Year Systems Model." Renewable Energy World. April 28, 2017. https://www.renewableenergyworld.com/articles/2017/04/pv-plantrepowering-the-utility-50-year-systems-model.html.

Beetz, Becky. "The Sustainability Game Changers." PV Magazine. December 5, 2019. https://www.pv-magazine.com/2019/12/05/the-sustainability-game-changers/.

Besiou, Maria, and Luk Van Wassenhove. "Closed-loop Supply Chains for Photovoltaic Panels: A Case-Based Approach.” Journal of Industry Ecology 20, no. 4 (July 2015): 929-37. https://doi.org/10.1111/jiec.12297.

Broun, Carolina N. and James T. O'Reilly. "RCRA and Superfund: A Practice Guide, The Concept of "Discarded,"3d § 2:10 (2009).

Celik, Illke, Zhaoning Song, Adam B. Philips, Michael J. Heben, and Defne Apul. "Life Cycle Analysis of Metals in Emerging Photovoltaic (PV) Technologies: A Model Approach to Estimate Use Phase Leaching." Journal of Cleaner Production 186 (June 2018): 632-639. https://www.sciencedirect.com/science/article/pii/S0959652618307200?via\%3Dihub.

CESA (Clean Energy States Alliance). Standards and Requirements for Solar Equipment, Installation, and Licensing and Certification: A Guide for States and Municipalities. February 2017. https://www.cesa.org/assets/2017-Files/Standards-and-Requirements-for-Solar.pdf. 
Choi, Jun-Ki. 2017. "A Case Study of Sustainable Manufacturing Practice: End-of-Life Photovoltaic Recycling," Sustainable Design and Manufacturing 2017, Smart Innovation, Systems and Technologies 68: (April 2017): 277-79.

https://link.springer.com/chapter/10.1007\%2F978-3-319-57078-5_27\#citeas.

CitiGreen. "Is My Roof Strong Enough to Support a Solar System?” March 11, 2019. https://citigreeninc.com/is-my-roof-strong-enough-to-support-a-solar-system/.

Corcelli, F., M. Ripa, and S. Ulgiati. "End-of-Life Treatment of Crystalline Silicon Photovoltaic Panels. An Energy-Based Case Study." Journal of Cleaner Production 161 (September 2017): 1129-1142. https://www.sciencedirect.com/science/article/pii/S0959652617309563?via\% 3Dihub.

CPSC (California Product Stewardship Council). "Solar Panel Recycling in California." Webinar. February 3, 2020. https://www.calpsc.org/product-page/solar-panel-recycling-in-ca.

CPUC (California Public Utilities Commission). 2019a. "Rule 21 Interconnection.” Accessed September 19, 2019: https://www.cpuc.ca.gov/Rule21/.

— 2019b. "From Cradle to Grave: Addressing End-of-Life Management for Photovoltaic Panels and Batteries for Electric Vehicles and Energy Storage Workshop." April 3, 2019. San Francisco, California. http://www.adminmonitor.com/ca/cpuc/ workshop/20190403/.

CPUC and CalRecycle (California Department of Resources Recycling and Recovery). Memorandum of Understanding Between the California Public Utilities Commission and the California Department of Resources Recycling and Recovery. January 8, 2019. https://www. cpuc.ca.gov/uploadedFiles/CPUC Public_Website/Content/Utilities and Industries/Energy Electricity_and_Natural_Gas/CPUC\%20\%20CalRecycle_MOU_Fully\%20Exctd 1-8-19.pdf.

CSSA. (California Solar + Storage Association). 2020. "New Regulations for End-of-Life PV Modules Webinar." November 10, 2020. https://register.gotowebinar.com/recording/3084273 $\underline{463311327760 .}$.

Cura Orphanage. "Solar for CURA." Accessed September 25, 2019: https://www.curaorphanage .org/solar-for-cura.

Curtis, Taylor L., Garvin Heath, Andy Walker, Jal Desai, Edward Settle, and Cesar Barbosa. Best Practices at the End of the Photovoltaic System Performance Period. NREL/TP-6A2078678. Golden, CO: NREL. February 2021 a. https://www.nrel.gov/docs/fy21osti/78678.pdf. 2021b. Curtis, Taylor L., Heather Buchanan, Garvin Heath, Stephanie Shaw, and Ben Kaldunski. Solar Photovoltaic Module Recycling: A Survey of U.S. Policies and Initiatives. NREL/TP-6A20-74124. Golden, CO: NREL. March 2021. https://www.nrel.gov/docs/fy21osti/ 74124.pdf.

D'Adamo, Idiamo, Michela Miliacca, and Paolo Rosa. "Economic Feasibility for Recycling of Waste Crystalline Silicon Photovoltaic Modules," International Journal of Photoenergy 2017: 16. https://doi.org/10.1155/2017/4184676. 
Daniels Training Services, Inc. 2018. "The Characteristic of Toxicity for Hazardous Waste in California." Accessed September 19, 2019: https://danielstraining.com/the-characteristic-oftoxicity-for-hazardous-waste-in-california/.

DOE (U.S. Department of Energy). 2011. Solar Powering Your Community: A Guide for Local Governments. January 2011. https://www.nrel.gov/docs/fy11osti/47692.pdf.

DOI (U.S. Department of the Interior). "Interior Seeks Public Comment on Draft List of 35 Minerals Deemed Critical to the U.S. National Security and the Economy." Last updated February 16, 2018. https:/www.doi.gov/pressreleases/interior-seeks-public-comment-draft-list35-minerals-deemed-critical-us-national.

Dominguez, Adriana, and Roland Geyer. "Photovoltaic Waste Assessment in Mexico." Resources, Conservation, and Recycling Journal 127 (December 2017): 29-41. https://www.sciencedirect.com/science/article/pii/S0921344917302525.

Dong, Liang, Tsuyoshi Fujita, Ming Dai, Yong Geng, and Jinzheng Ren. "Towards Preventative Eco-Industrial Development: An Industrial and Urban Symbiosis Case in One Typical Industrial City in China." Journal of Cleaner Production 114 (February 2016): 387-400. https://www.sciencedirect.com/science/article/pii/S0959652615005557.

Driscoll, William. 2020. “Advocates Seek Solar on All New Houses in Ten States.” PV Magazine. June 23, 2020. https://pv-magazine-usa.com/2020/06/23/advocates-seek-solar-on-allnew-houses-in-10-states/.

DTSC (California Department of Toxic Substances Control). 2019a. Defining Hazardous Waste. Accessed September 19, 2019: https://dtsc.ca.gov/wpcontent/uploads/sites/31/2018/05/DefiningHazardousWaste.pdf.

- 2019b. "Public Seminar on Universal Waste and Proposed Regulations for the Management of Waste Photovoltaic Modules as Universal Waste.” March 25, 2019. Sacramento, California. https://dtsc.ca.gov/photovoltaic-modules-pv-modules-universal-waste-managementregulations/.

- 2019c. "Public Availability of Post-Hearing Changes and Documents Added to the Rulemaking File." September 9, 2019. https://dtsc.ca.gov/wp-content/uploads/sites/31/2019/01.20190909-PVM-15-Day-NOPA-Final.pdf.

- 2019d. "Attachment to Economic and Fiscal Impact Statement (STD 399)." Accessed July 23, 2019. https://dtsc.ca.gov/wp-content/uploads/sites/31/2019/01.-20190909-PVM-15-DayNOPA-Final.pdf.

. n.d. "Solar Panel FAQs." Accessed September 30, 2020. https://dtsc.ca.gov/solar-panelfaqs/\#easy-faq-348309. 
Ehrhard, Peter. 2019. "Researchers Urge Midwestern States to Recycle Solar Panels Efficiently." Missouri University of Science and Technology: News and Events. October 14, 2019.

https://news.mst.edu/2019/10/researchers-urge-midwestern-states-to-start-recycling-solarpanels/.

Ellen MacArthur Foundation. "What is the Circular Economy?" 2020. https://www.ellenmacarthurfoundation.org/circular-economy/concept.

EnergySage. 2018. What is the Average Solar Panel Size?, https://news.energysage.com/averagesolar-panel-size-weight/.

EPA. n.d. "Frequent Questions Related to Hazardous Waste Recycling, the Definition of Solid Waste and Other Exemptions and Exclusions." Accessed September 25, 2020. https://www.epa.gov/ $\underline{\mathrm{hw} / \text { frequent-questions-related-hazardous-waste-recycling-definition-solid-waste-and-other- }}$ exemptions\#reclaim.

1988. "Clarification of Issue Pertaining to Household Hazardous Waste Collection Programs." Office of Solid Waste and Emergency Response. Memorandum. November 1, 1988. https://rcrapublic.epa.gov/files/11377.pdf.

-2005. "Introduction to Hazardous Waste Identification.” Accessed September 30, 2020. https://www.epa.gov/sites/production/files/2015-09/documents/hwid05.pdf.

. 2014. "RCRA Orientation Manual 2014." Accessed September 30, 2020. https://www.epa.gov/sites/production/files/2015-07/documents/rom.pdf.

_. 2019a. "Differences Between Universal Waste and Hazardous Waste Regulations." Last modified March 11, 2019. https:/www.epa.gov/hw/differences-between-universal-waste-andhazardous-waste-regulations.

. 2019b. "SW-846 Test Method 1311: Toxicity Characteristic Leaching Procedure." Last modified December 20, 2016. https://www.epa.gov/hw-sw846/sw-846-test-method-1311toxicity-characteristic-leaching-procedure.

- 2019c. "Frequent Questions on International Agreements on Transboundary Shipments of Waste." Last modified March 26, 2019. https://www.epa.gov/hwgenerators/frequentquestions-international-agreements-transboundary-shipments-waste.

- 2019d. "State Universal Waste Programs in the United States." Last modified August 30, 2019. https://www.epa.gov/hw/state-universal-waste-programs-united-states.

- 2019e. "State Authorization under the Resource Conservation and Recovery Act (RCRA)." Last modified May 21, 2019. https://www.epa.gov/rcra/state-authorization-underresource-conservation-and-recovery-act-rcra. 
—.2019f. "International Agreements on Transboundary Shipments of Hazardous Waste." Last modified April 1, 2019. https://www.epa.gov/hwgenerators/international-agreementstransboundary-shipments-hazardous-waste.

_. 2020a. "Household Hazardous Waste (HHW)." Last modified May 13, 2020. https://www.epa.gov/hw/household-hazardous-waste-hhw.

—. 2020b. "Hazardous Waste Manifest System.” Last modified March 2, 2020. https://www.epa.gov/hwgenerators/hazardous-waste-manifest-system\#obtaining.

Evergreen Solar. "Size of Solar Panels." Accessed February 28, 2020:

https://evergreensolar.com/installation/size-of-solar-panels/.

First Solar. 2019. Leading the World's Sustainable Energy Future: 2019 Corporate Factsheet. http://www.firstsolar.com/-/media/First-Solar/Documents/Corporate-

Collaterals/FS_Corporate_Factsheet.ashx.

Gaba, Jeffery M. "Rethinking Recycling." Lewis and Clark Law Review 38 (Nov. 14, 2008):

101-158. https://law.lclark.edu/live/files/17320-38-4gaba.

1989. "Solid Waste and Recycled Materials Under RCRA: Separating Chaff from Wheat." Ecology of Law Quarterly 16 (1989): 623-666. https://lawcat.berkeley.edu/record/ $1113471 ? \ln =$ en.

Ghisellini, Patrizia, Catia Cialani, and Sergio Ulgiati. “A Review on Circular Economy: The Expected Transition to a Balanced Interplay of Environmental and Economic Systems." Journal of Cleaner Production 114 (February 2016): 11-32. https://www.sciencedirect.com/science/ article/pii/S0959652615012287.

Good Sun. "Current Projects.” Good Sun. Accessed September 24, 2019:

https://www.goodsun.life/current-projects.html.

Governor Phil Murphy. "Governor Murphy Takes Action on Legislation.” August 9, 2019. https://nj.gov/governor/news/news/562019/approved/20190809b.shtml.

Green Coast. “Solar Panel Roof Load Calculator: Will My Roof Support Solar Panels?” Last updated November 19, 2019. https://greencoast.org/solar-panel-roof-load-calculator/.

Harms, Rainer, Jonathon D. Linton. Willingness to Pay for Eco-Certified Refurbished Products: The Effects of Environmental Attitudes and Knowledge. Journal of Industrial Ecology (June 2015). https://onlinelibrary.wiley.com/doi/full/10.1111/jiec.12301.

Heath, Garvin A., Timothy J. Silverman, Michael Kempe, Michael Deceglie, Dwarakanath Ravikumar, Timothy Remo, Hao Cui, Parikhit Sinha, Cara Libby, Stephanie Shaw, Keiichi Komoto, Karsten Wambach, Evelyn Butler, Teresa Barnes, and Andreas Wade. Research and Development Priorities for Silicon Photovoltaic Module Recycling to Support a Circular Economy. Nature Energy 5 (July 2020): 502-510. https://www.nature.com/articles/s41560-020$\underline{0645-2}$. 
Holm, Nancy, and Jennifer Martin. "Planning for Solar PV End-of-Life Options." Illinois Sustainable Technology Center. 2019. https://www.ideals.illinois.edu/handle/2142/105404.

IBC (International Building Code). 2012. "Code Provisions Applicable to All Roof Assemblies." Accessed June 8, 2020: https://codes.iccsafe.org/content/IBC2012/chapter-1-scope-andadministration.

ICC (International Code Council). "Code Adoption Map.” December 2018. https://www.iccsafe.org/wp-content/uploads/Code_Adoption_Maps.pdf.

IEA (International Energy Agency). 2020. "Renewables 2020: Analysis and Forecast to 2025." November 2020. https://www.iea.org/reports/renewables-2020.

IEEE. "IEEE 1547-2018 Standard for Interconnection and Interoperability of Distributed Energy Resources with Associated Electric Power Systems Interfaces.” April 2018. https://standards.ieee.org/standard/1547-2018.html.

IHS Markit. 2020. "Grid Stability: How PV Inverters Can Help Overcome Challenges in the $21^{\text {st }}$ Century." Accessed March 8, 2021. https://cdn.ihsmarkit.com/www/pdf/1220/Grid-StabilityHow-PV-Inverters-Can-Help-Overcome-Challenges.pdf.

Intermountain Wind \& Solar. "Solar Panel 101: Understanding Module Size and Weight." Accessed February 28, 2020. https://www.intermtnwindandsolar.com/solar-panels-101understanding-module-size-and-weight/.

ISO New England. 2020. “About Us: What We Do.” Accessed June 3, 2020. https://www.isone.com/about/what-we-do/.

ISTC (Illinois Sustainable Technology Center). n.d. "Solar Panel Recycling Initiative." https://www.istc.illinois.edu/cms/One.aspx?portalId=427487\&pageId=1010909.

Johnson, Stephen. "Recyclable Materials and RCRA's Complicated, Conflicting, and Costly Definition of Solid Waste." 21 E.L.R. 10357. 1991. https://elr.info/sites/default/files/articles/ 21.10357.htm.

Kalmykova, Yuliya, Madumita Sadagopan, and Leonardo Rosardo. "Circular Economy-From Review Theories and Practices to Development of Implementation Tools." Resources, Conservation, and Recycling Journal 135 (August 2018): 190-201. https://www.sciencedirect.com/science/article/pii/S0921344917303701?via\%3Dihub.

Krueger, Lisa. "First Solar's Module Collection and Recycling Program." First Solar, Vice President of Sustainable Development Presentation. 2010. http://www.solarscorecard.com/panel/pdf/Lisa_Krueger.pdf.

Leslie, Joswin. "Dependence of Toxicity Test Results on Sample Removal Methods of PV Modules." Master's thesis, Arizona State University, 2018. https://repository.asu.edu/attachments/207447/content/Leslie asu 0010N 18113.pdf. 
Libby, Cara and Stephanie Shaw. 2018. Solar PV Module End of Life: Options and Knowledge Gaps for Utility-Scale Plants. EPRI Technical Update Report 3002014407. Palo Alto, CA:

Electric Power Research Institute.

Ludt, Billy. 2019. "How to Decommission a Solar Array, and Why It's Impact to Plan Ahead." Solar Power World. March 11, 2019. https://www.solarpowerworldonline.com/2019/03/how-todecommission-a-solar-array-and-why-its-important-to-plan-ahead/.

Lydic, Brian. 2018. "Smart Inverter Update: New IEEE 1547 Standard and State Implementation Efforts." Interstate Renewable Energy Council. July 23, 2018. https://irecusa.org/2018/07/smartinverter-update-new-ieee-1547-standards-and-state-implementation-efforts/.

Minnesota Department of Commerce. "Minnesota Solar Fact Sheet.” February 2019. https://mn.gov/commerce-stat/pdfs/solar-fact-sheet.pdf.

Minnesota Solar Panel Recycling Strategy Working Group. "June 27, 2019 Meeting." Minnesota Pollution Control Agency. June 27, 2019.

Mints, Paula. 2020. "Photovoltaic Manufacturer Capacity, Shipments, Price \& Revenues (Report SPV-Supply8).” SPV Market Research. April 2020.

Mulvaney, Dustin. 2019. Solar Power: Innovation, Sustainability, and Environmental Justice. Oakland, California: University of California Press. www.jstor.org/stable/j.ctvd1c6zh.

- 2014. "Solar Energy Isn't Always as Green as You Think." IEEE Spectrum. November 12, 2014. https://spectrum.ieee.org/green-tech/solar/solar-energy-isnt-always-as-green-as-youthink.

NCSL (National Conference of State Legislatures). 2021. "State Renewable Portfolio Standards and Goals." January 1, 2021. https://www.ncsl.org/research/energy/renewable-portfoliostandards.aspx.

NEC (National Electrical Code). 2014. NEC 690.12 Rapid Shutdown for String Inverters on Flat Roofs. https://www.nfpa.org/codes-and-standards/all-codes-and-standards/list-of-codes-andstandards/detail?code $=70$.

NFPA (National Fire Protection Association). National Electrical Code. Last modified August 6, 2019. https://www.nfpa.org/codes-and-standards/all-codes-and-standards/list-of-codes-andstandards/detail?code $=70$.

NCDEQ (North Carolina Department of Environmental Quality). "Final Report on the Activities Conducted to Establish a Regulatory Program for the Management and Decommissioning of Renewable Energy Equipment.” January 1, 2021. https://files.nc.gov/ncdeq/Environmental\%20Management\%20Commission/EMC\%20Meetings/ 2021/jan2021/attachments/AttachA-21-05-H329---FINAL-REPORT-Ellen--1-.pdf. 
NIST (National Institute of Standards and Technology). "Circular Economy in the High Tech World Workshop.” January 28, 2021. Gaithersburg, Maryland. https://www.nist.gov/newsevents/events/2021/01/circular-economy-high-tech-world.

NREL. 2019a. "Photovoltaics in the Circular Economy Workshop.” March 1, 2019. Golden, Colorado.

- 2019b. "Your Renewable Energy Technology is Growing Old—What's Next?" April 22, 2019. https://www.nrel.gov/news/features/2019/your-renewable-energy-technology-isgrowing-old-whats-next.html.

. 2020. "Renewables Rescue Stability as the Grid Loses Spin.” September 15, 2020. .

Oreski, Gernot. 2020. "Co-Extruded Backsheets for PV Modules: Past Approaches and Recent Developments.” Polymer Competence Center Leoben GmbH. https://www.nist.gov/system/files/ documents/2020/01/15/Oreski.pdf.

Osborne, Mark. 2019. "DuPont's 2019 'Global Reliability Study' Warns of Rising Backsheet Delamination and Cracking." PV Tech. June 19, 2019. https://www.pv-tech.org/news/duponts2019-global-pv-reliability-study-warns-of-rising-backsheet-delamina.

Parnell, John. 2020. "Solar Repowering Could Be Coming Sooner Than You Think." Greentech Media. February 24, 2020. https://www.greentechmedia.com/articles/read/solar-repoweringcould-be-coming-sooner-than-you-think.

Perea, Austin, Colin Smith, Michelle Davis, Xiaojing Sun, Bryan White, Molly Cox, and Gregson Curtin. 2021. "U.S. Solar Market Insight (Report Excel Data): 2020 Year in Review." Wood Mackenzie. February 2021.

PHMSA (Pipeline and Hazardous Materials Safety Administration). 2017a. "International Civil Aviation Organization.” Last modified September 1, 2017.

https://www.phmsa.dot.gov/international-program/international-civil-aviation-organization.

_. 2017b. "International Maritime Organization.” Last modified September 1, 2017. https://www.phmsa.dot.gov/international-program/international-maritime-organization.

Pickerel, Kelly. 2020. "Solar's Silent Killer: Backsheets Are Shortening Some Project Lifespans." Solar Power World. January 15, 2020.

https://www.solarpowerworldonline.com/2020/01/solars-silent-killer-backsheets-are-shorteningproject-lifespans/.

. 2015. "What Are The Different Types of Solar Panels." Solar Power World. July 30, 2015. https://www.solarpowerworldonline.com/2015/07/what-are-the-different-types-of-solarmodules/.

PSI (Product Stewardship Institute). "Solar Panel Stewardship: The Future is Now" Webinar (January 4, 2018). 
Ramos-Ruiz, Adriana, Jean V. Wilkening, James A. Field, and Reyes Sierra-Alvarez. "Leaching of Cadmium and Tellurium from Cadmium Telluride (CdTe) Thin-Film Solar Panels Under Simulated Landfill Conditions." Journal of Hazardous Materials 365 (August 2017): 57-64. https://www.sciencedirect.com/science/article/pii/S0304389417303084?via\%3Dihub.

REH (Renewable Energy Hub). "What Are Solar Cells Made Up Of?” Accessed March 15, 2021: https://www.renewableenergyhub.co.uk/main/solar-panels/what-is-a-solar-cell-made-upof/.

Salim, Hengky K., Rodney A. Stewart, Oz Sahin, and Michael Dudley. "Drivers, Barriers and Enablers to End-of-Life Management of Solar Photovoltaic and Battery Energy Storage Systems: A Systematic Literature Review." Journal of Cleaner Production 211 (February 2019): 537-54. https://www.sciencedirect.com/science/article/pii/S0959652618336321.

Schmid, Melissa Ann. 2020. "Policy Changes Open Doors to Solar Secondary Market." North American Clean Energy. March 15, 2020. http://www.nacleanenergy.com/articles/37174/policychanges-open-doors-to-the-solar-secondary-market.

SEIA (Solar Energy Industries Association). 2019a. "End-of-Life Considerations for Solar Photovoltaics." May 2019. https://www.seia.org/sites/default/files/2019-05/SEIA-EOLConsiderations-PV-Factsheet-May2019.pdf.

—. 2019b. "SEIA National PV Recycling Program.” https://www.seia.org/initiatives/seianational-pv-recycling-program.

—. 2019c. "About SEIA.” https://www.seia.org/about.

. 2020. “Solar Market Insight Report.” December 2020. https://www.seia.org/researchresources/solar-market-insight-report-2020-q4.

Shellenberger, Michael. "If Solar Panels Are So Clean, Why Do They Produce So Much Toxic Waste?” Forbes Magazine. May 23, 2018.

https://www.forbes.com/sites/michaelshellenberger/2018/05/23/if-solar-panels-are-so-cleanwhy-do-they-produce-so-much-toxic-waste/?sh=5da78b10121c.

Sherwood, Larry, Bob Backstorm, and Dwayne Sloan et al. "Fire Classification Rating Testing of Stand-Off Mounted Photovoltaic Modules and Systems." August 2013.

http://www.solarabcs.org/about/publications/reports/flammability-testing/pdfs/SolarABCs-362013-1.pdf.

Sinha, Parikhit, Sukwant Raju, Karen Drozdiak, and Andreas Wade. 2018. "Life Cycle Management and Recycling of PV Systems." Photovoltaics International 38: 45-50.

Smith L., Brittany and Robert Margolis. 2019. Expanding the Photovoltaic Supply Chain in the United States: Opportunities and Challenges. NREL/TP-6A20-73363. Golden, CO: NREL. July 2019. https://www.nrel.gov/docs/fy19osti/73363.pdf. 
Solar ABCs (Solar America Board for Codes and Standards). 2011. "Impacts on Photovoltaic Installations of Changes to the 2012 International Codes."

http://www.solarabcs.org/about/publications/reports/2012Codes/pdfs/ABCS-22whitepaper.pdf.

Stolz, Philippe, Rolf Frischknecht, Karsten Wambach, Parikhit Sinha, and Garvin Heath. Life Cycle Assessment of Current Photovoltaic Module Recycling. International Energy Agency Photovoltaic Power Systems Programme. IEA PVPS Task 12. Report \#T12-13:2018. 2018. ISBN 978-3-906042-69-5. http://iea-pvps.org/index.php?id=461.

Sun, Xiaojing, Lindsay Cherry, and Molly Cox. 2020a. "Foresight 20/20: Solar Supply Chain, Systems and Technology.” Wood Mackenzie. January 2020. https://www.woodmac.com/ourexpertise/focus/Power--Renewables/solar-systech-foresight2020?utm_source=gtm\&utm_medium $=$ article\&utm_campaign=wmpr_fs2020systech.

Sun, Xiaojing, Colin Smith, and Ravi Manghani. 2020b. "Coronavirus: U.S. Solar PV Supply Chain and Utility Scale Market Risk.” Wood MacKenzie. March 2020.

Tura, Nina., Jyri Hanski, Tuomas Ahola, Matias Stahle, and Sinia Piiparinen. "Unlocking Circular Economy Business: A Framework of Barriers and Drivers." Journal of Cleaner Production 212 (March 2019): 90-98. https://www.sciencedirect.com/science/article/pii /S0959652618336059.

Tsanakas, John A., Arid van der Heide, Tadas Radavicius, Julius Denafas, Elizabeth Lemaire, and Ke Wang. "Towards a circular supply chain for PV modules: Review of today's challenges in PV recycling, refurbishment, and recertification. Progress in Photovoltaics. (June 2020). 28:6. https://onlinelibrary.wiley.com/doi/10.1002/pip.3193.

UL (UL LLC.). 2004. "UL 790 Standard Test Methods for Fire Tests of Roof Coverings." https://standardscatalog.ul.com/standards/en/standard 7908.

- 2010. "1741 Standard for Inverters, Converters, Controllers and Interconnection System Equipment for Use with Distributed Energy Resources." Accessed September 19, 2019: https://standardscatalog.ul.com/standards/en/standard_1741_2.

- 2013. "UL 1703 Standard for Safety for Flat-Plate Photovoltaic Modules and Panels." https://standardscatalog.ul.com/standards/en/standard $1703 \quad 3$.

. 2019. "1974 Standard for Evaluation for Repurposing Batteries.” Accessed September 19, 2019. https://standardscatalog.ul.com/ProductDetail.aspx?productId=UL1974.

USGS (United States Geological Survey). 2020a. "Copper." Mineral Commodity Summaries. January 2020. https://pubs.usgs.gov/periodicals/mcs2020/mcs2020-copper.pdf.

_. 2020b. “Aluminum.” Mineral Commodity Summaries. January 2020. https://pubs.usgs.gov/periodicals/mcs2020/mcs2020-aluminum.pdf.

2020c. “Tellurium.” Mineral Commodity Summaries. January 2020.

https://pubs.usgs.gov/periodicals/mes2020/mcs2020-tellurium.pdf. 
Weckend, Stephanie, Andreas Wade, and Garvin Heath. End-of-Life Management: Solar Photovoltaic Panels. International Renewable Energy Agency and International Energy Agency Photovoltaic Power Systems. IEA-PVPS Report Number T12-06:2016. http://ieapvps.org/fileadmin/dam/public/report/technical/IRENA_IEAPVPS End-ofLife_Solar_PV_Panels_2016.pdf.

Wesoff, Eric and Becky Beetz. "Solar Panel Recycling in the U.S.: A Looming Issue that Could Harm Industry Growth and Reputation." PV Magazine. December 3, 2020. https://pv-magazineusa.com/2020/12/03/solar-panel-recycling-in-the-us-a-looming-issue-that-could-harm-growthand-reputation/.

Wholesale Solar. 2011. www.wholesalesolar.com/solar-panels.html.

WSDE (Washington State Department of Ecology). 2020. Manufacturer Plan Guidance for the Photovoltaic Module Stewardship Program. Accessed June 3, 2020:

https://fortress.wa.gov/ecy/publications/documents/1907014.pdf.

. n.d. "Universal Waste." Accessed September 30, 2020.

https://ecology.wa.gov/Regulations-Permits/Guidance-technical-assistance/Dangerous-wasteguidance/Common-dangerous-waste/Universal-waste.

- Conditional Exclusion for Electronic Wastes. 2007. https://fortress.wa.gov/ecy/publications/documents/0204017.pdf.

$\mathrm{Xu}$, Yan, Jinhui Li, and Quanyin Tan. "Global Status of Recycling Waste Solar Panels: A Review." Waste Management 75 (February 2018): 450-58. https://www.researchgate.net/publication/323269505_Global_status_of_recycling_waste_solar_p anels A review. 


\section{Legislative and Executive Documents}

\section{Executive Orders}

Exec. Order No. 13817, 82 Fed. Reg. 60835 (2017), A Federal Strategy to Ensure Secure and Reliable Supplies of Critical Minerals.

\section{Federal and State Statutes}

42 U.S.C. $\S \S 6901-6992 k$ (1976), Resource Conservation and Recovery Act.

49 U.S.C. $\S \S 5101-5128$ (1970), Hazardous Materials Transportation Act.

Wash. Rev. Code $\S 70$ A.510.010 (2017), Photovoltaic module stewardship and takeback program.

Cal. Health and Safety Code $\S 25189$ (2018).

Federal and State Regulations

40 C.F.R. $\S 19.4,40$ CFR $\S 19.4$ - Statutory Civil Penalties, As Adjusted for Inflation, and Tables

40 C.F.R. $§ \S 239-282$, Solid Wastes.

40 C.F.R. $\S \S 171-80$, Hazardous Materials Regulations.

49 C.F.R. $\S \S 107.1-809$, Hazardous Materials Program Procedures.

Universal Waste Rule, 60 Fed. Reg. 25,492, 25,492 (May 11, 1995) (to be codified at 40 C.F.R. Parts 9, 260, 261, 262, 264, 265, 266, 268, 270, and 273).

N.J. Admin. Code $§ ~ 7: 26 A-1.3 ~(2017)$.

Wash. Admin. Code $\S 173-303-040$ (2019).

Cal. Code Regs. tit. $22 \S \S 66260.1$ - 66260.12, Hazardous Waste Management System: General, Definitions (2020).

Cal. Code Regs. tit. $22 \S 66261.9$, Requirements for Universal Waste (2020).

Cal. Code Regs. tit. $22 \S \S 66273.1$ - 66273.101, Standards for Universal Waste Management (2020).

Cal. Code Regs. tit. 24, $\S 110.10$ (2019).

State Session Laws

2019 N.J. Sess. Law Serv. Ch. 215 (West).

2019 N.C. Sess. Law 2019-132. 


\section{State Bills}

H.B. 1333, 31st Leg., Reg. Sess. (Haw. 2021).

H.B. 5525, 2021 Leg., Reg. Sess. (R.I. 2021).

S.B. 207, 2021-2022 Leg., Reg. Sess. (Cal. 2021).

S.B. 5939, 65th Leg., 3rd Spec. Sess. (Wash. 2018). 


\section{Interviews}

Cara Libby. Electrical Power Research Institute. Email. January 14, 2021.

Daniel Stoehr. Daniels Training Services, Inc.. Teleconference. August 30, 2019.

Eric Stikes and Vince Lucia. Good Sun. Teleconference. August 26, 2019.

Eric Stikes. Good Sun. Email. January 22, 2020.

Eric Stikes. Good Sun. Email. May 3, 2019.

Evelyn Butler. Solar Energy Industries Association. Teleconference. February 8, 2019.

Gary Winslow. MiaSolé. Email. March 12, 2019.

John Martorano. Magnum Computer Recycling. Teleconference July 31, 2019.

Jordan Rivera. U.S. Department of Transportation, Headquarters. Email. September 30, 2020.

Matthew Garamone. Environmental Management Services, LLC., and Parikhit Sinha. First Solar. Teleconference. March 4, 2019.

Matthew Garamone. Environmental Management Services, LLC., and Parikhit Sinha. First Solar. Teleconference. August 26, 2019.

Neal Suchak. U.S. Department of Transportation, Headquarters. Email. September 30, 2020.

Parikhit Sinha. First Solar. Email. August 26, 2019.

Paulina Kolic. CalRecycle. Email. September 6, 2019.

Sam Vanderhoof. Recycle PV. Teleconference. September 5, 2019.

Teresa Bui. CalRecycle. Email. January 8, 2021.

Tim Kimmel. Cleanlites Recycling. Teleconference. March 5, 2019. 